\title{
Seasons and Nutrition at the Kenya Coast
}

Jan Hoorweg

Dick Foeken

Wijnand Klaver 
SEASONS AND NUTRITION AT THE KENYA COAST 

African Studies Centre

Research Series

$7 / 1995$

\section{Seasons and Nutrition at the Kenya Coast}

Jan Hoorweg, Dick Foeken \& Wijnand Klaver 


\section{ISBN 1856289141}

(C) African Studies Centre, Leiden, 1995

All rights reserved. No part of this publication may be reproduced, stored in a retrieval system, or transmitted in any way or by any means, electronic, mechanical, photocopying, recording or otherwise withouth the prior permission of the publisher. 


\section{Contents}

List of Tables vii

List of Figures viii

List of Maps viii

Summary ix

\section{Introduction 1}

2 Seasonality in Sub-Sahara Africa 5

2.1 Introduction 5

2.2 Climatic seasonality and the agrarian cycle 6

2.3 Effects of climatic seasonality 9

2.4 Preventing seasonal stress 16

2.5 Acute seasonal stress 21

2.6 Conclusion 23

3 Kenya's Coastal Lowlands: Kwale and Kilifi Districts

3.1 Infrastructure and population 28

3.2 Topography, rainfall and soils 29

3.3 Climatic seasonality 33

3.4 Agro-ecological zones 35

3.5 Agriculture 38

3.6 Farming systems 42

3.7 Farm labour 44

3.8 Off-farm employment 45

3.9 Food consumption, nutritional status and health 46

3.10 Study method 48

4 Socio-Economic Conditions 50

4.1 Demographic characteristics and living conditions 50

4.2 Agriculture 54

4.3 Off-farm employment 61

4.4 Household income 64

4.5 Conclusion 66 
5 Household Food Consumption 68

5.1 Food habits 68

5.2 Energy and protein intake 70

5.3 Seasonal variation in energy intake 74

5.4 Conclusion 79

6 Nutritional Status of Women and Children 81

6.1 Introduction 81

6.2 Adult women 82

6.3 Young children 85

6.4 Conclusion 91

7 Discussion 95

7.1 Resource management 97

7.2 Seasonality in nutrition 100

7.3 Determinants of seasonality 102

7.4 Implications 104

\section{Appendices}

1 Potential crop yields by research area and season 108

2 Research areas 110

3 Survey procedures 111

4 Households and household members by residency and research area 112

5 Full-time residents by age group and research area 112

6 Adult women and young children with anthropometric measures recorded 112

7 Energy intake from subsistence origin by research area and survey round 113

8 Energy intake from purchased origin by research area and survey round 113

9 Nutritional status of adult women by research area and survey round 114

10 Nutritional status of adult women by a.e.zone, income class and survey round 114

11 Height and weight growth of children by research area and survey round 115

12 Height growth velocity of children by a.e.zone, income class and survey round 116

13 Weight growth velocity of children by a.e.zone, income class and survey round 116

Notes 117

References $\quad 127$ 


\section{List of Tables}

1 Population parameters by administrative unit 30

2 Climatic seasonality at selected stations 34

3 Mean annual rainfall and years with deviating rainfall 35

$4 \quad$ Agricultural land and number of farm families by agro-ecological zone 37

5 Agro-ecological characteristics of research areas 39

6 Household income in Coast Province by income source and region (1974-75)

7 Data collection 48

8 Average household size by research area 51

9 Male residency by research area 51

10 Houses, rooms and occupants by research area 52

11 Sanitary conditions by research area 53

12 Farm size and land use by research area 54

13 Farm labour by research area 55

14 Cereals and cassava production by research area 56

15 Food self-sufficiency by research area 57

16 Cash crop cultivation by research area 58

17 Livestock ownership by research area 59

18 Value of agricultural production by type of activity and research area 60

19 Agricultural productivity by research area 60

20 Frequency of off-farm employment by research area 61

21 Off-farm workers: place of work and residency by research area 62

22 Type of off-farm employment by research area 63

23 Household income from off-farm employment by research area 64

24 Household income by research area 65

25 Household income and poverty estimates by agro-ecological zone 65

26 Income composition by income class 66

27 Energy intake by survey round 70

28 Energy intake by food group and survey round 71

29 Contribution of macro-nutrients to energy intake by survey round 71

30 Protein intake by survey round 72

31 Origin of energy intake by survey round 72

32 Energy intake (subsistence) by survey round and food group 74

33 Energy intake (purchases) by survey round and food group 75

34 Energy intake by research area and food origin 75

35 Energy intake by research area and survey round 76

36 Variations in energy intake by research area and food origin 77

37 Seasonal variations in energy intake by agro-ecological zone 78

38 Seasonal variations in energy intake by income class 79

39 Adult women: anthropometry by survey round 83

40 Seasonal variation in nutritional status of adult women by research area 83

41 Seasonal variation in nutritional status of adult women by agro-ecological zone

42 Seasonal variation in nutritional status of adult women by income class 85

43 Summary of child anthropometry from different sources 86

44 Results for child anthropometry by age group 86 
45 Illness and malnutrition among young children by age group and survey round

46 Child growth velocities by age group and season 88

47 Seasonal variation in child growth velocities by research area 89

48 Seasonal variation in child growth velocities by agro-ecological zone 90

49 Seasonal variation in child growth velocities by income class 90

50 Value of agricultural production by wage income 122

\section{List of Figures}

1 Hypothetical fluctuations of energy requirements, energy intake and body weight in unimodal and bimodal tropical climates 14

2 Topographical cross-section of Kilifi District 31

3 Mean monthly rainfall as a percentage of mean annual rainfall 32

4 Monthly rainfall as percentage of year total 38

5 Agricultural calendar for Kwale and Kilifi Districts 44

6 Energy intake by food group and food origin 73

\section{List of Maps}

1 Sub-Sahara Africa: dry months per annum 4

2 Seasonality index for Sub-Saharan Africa 4

3 Kwale-and Kilifi Districts: roads, service centres and research areas

4 Kwale and Kilifi Districts: agro-ecological zones 36 


\section{Summary}

This monograph reports on the seasonal fluctuations in food and nutrition that occur in Coast Province, Kenya, a region with a largely unimodal climate and generally low household incomes. Five survey rounds were held in selected locations in Kwale and Kilifi Districts between mid ' 85 and late ' 86 . A literature review is followed by the presentation of survey findings as regards socio-economic characteristics, food consumption and nutritional status. The last chapter discusses different implications.

Households, on average, had eight acres of land at their disposal, but in the agro-ecological zones, CL3 and CL4, that are more fertile and nearer the coastline, 40 per cent of the households had less than three acres. About a third of the land was used for food crop cultivation. Three-quarters of the households had employment income of some kind. More than half the workers had found employment outside the location and had to live away from home.

Household income averaged about sh.10,000 per year or about sh.2,000 per consumer unit. Wage income contributed 65 per cent to the total, the value of food crops accounted for 20 per cent, cash crops and livestock constituted the remaining 15 per cent. Compared with the results of earlier CBS surveys there was no improvement; more than 40 per cent of the rural population live below the 'food poverty line'. The low returns from agriculture mean that households dependent on agriculture are most at risk of food shortages.

There is little or no difference in household income between different agro-ecological zones despite the differences in agricultural potential. The number of poor households in three zones studied was very similar ( 40 per cent). Since wages provide the major income component, and since employment opportunities are not location-bound, the similarity is 
not surprising. At the same time there are large individual differences in the way people choose to realize their available resources. Areas in the same agro-ecological zone differ considerably from each other. There are even greater differences in income and income composition between households within the same area.

Energy intake averaged $2580 \mathrm{kcal}$. per consumer unit per day or about $400 \mathrm{kcal}$. below the estimated requirements. Almost 80 per cent of the energy is from carbohydrates (mostly maize) and the diet is rather monotonous with a low energy density. Only one-third of the staple food consumption over the year is home-produced in origin and two-thirds is purchased. Seasonal variation starts with variations in energy intake from subsistence origin when food stocks are progressively depleted. The variation in subsistence energy is higher in areas where consumption of subsistence energy is high and where cassava consumption is low. Food purchases compensate for the decreasing maize stocks and they were highest in May-June, during the long rains, even enabling an increase of energy intake during the cultivation season. Notably, there is no large energy deficit during the long rains, the period of high labour requirements. Energy intake levels and seasonal fluctuations were not different in the different agro-ecological zones. Households in the lowest income class did have the lowest energy intake but they did not show the highest seasonal variation; they spread the consumption of subsistence food more evenly than the other groups. The reason for these findings lies in the role of food purchases. Households from all agro-ecological zones and from all income classes depend to a large extent on income generation which provides a coping mechanism that allows, firstly, to preserve a large part of their food stocks throughout the year and, secondly, to purchase more food at the time when needed.

The seasonal fluctuation in weight among the adult women is, on average, small. Again, no systematic differences were found to exist between agro-ecological zones as a result of the important role of food purchases. The women in the poorest households showed the smallest seasonal fluctuations in BMI. As in earlier surveys, the nutritional condition of the children was poor compared with all of Kenya. The number of children with very low weights was greater. The percentage of children under five years with height retardation is about twice as high. The longitudinal analysis of growth velocities showed that spurts in height and weight growth occur at different times of the year. A height spurt occurs during December-February, the dry season, and a weight spurt occurs in March-May, the wet season.

The fluctuations in weight growth are greater than in height growth; the fluctuations are largest among the oldest age group. There is no difference in average weight growth or height growth of the children from different agro-ecological zones or different income classes. However, in the relatively prosperous households, the children grow quite evenly throughout the year, but in the very poor households, both weight growth and height growth are more uneven.

In conclusion, it is evident that to depend on farming is risky in a region where rainfall is very unpredictable and where many households are not able to produce enough food to cover yearly food needs, not even in a 'good' year. It is more practical to rely on food purchases, which can be spread out, so that seasonal fluctuations of energy balance can be 
mitigated. This is only possible if people have sufficient purchasing power to buy food and, perhaps even more important, if food is available at prices that are relatively low and stable. Given a choice, households will try to combine subsistence cultivation and wage employment. The actual resource mix is decided by internal household factors such as land ownership and available labour and external factors such as agro-ecological conditions and employment opportunities. Emphasis on crop cultivation demands access to land, high labour inputs and hard work during the cultivation season and carries risks because of climatic uncertainties. Emphasis on employment demands that at least some household members have skills that are wanted on the labour market. More in general, sufficient employment opportunities are needed which are sometimes themselves seasonal in nature.

The study population seems to have developed fairly successful strategies to cope with diminishing food stocks at the end of the agricultural year; despite the fact that household income levels are generally low, a large number of households falls below poverty levels, household energy intake is not more than that of peasant smallholders elsewhere in Kenya and the nutritional status of children is below other districts. The implications of the findings are reviewed from several angles. Firstly, against the background of the changes in livelihood that have occurred in rural Africa. Secondly, in respect of resource management and diversification strategies. Thirdly, concerning existing theories of child growth, in particular as regards the interaction between height and weight growth. Fourthly, the respective contributions of climate, productive organization, household income and individual characteristics are reviewed. Finally, the implications for development and policy are discussed. 



\section{Introduction}

The food and nutrition situation in Kenya gives reason for concern. The country has a high rate of population growth, in parts of the country pressure on land has become a serious constraint and food production has not kept pace with population increase. The pressure on land resources in Kenya threatens the future balance between national food demand and national food production. The existing agro-ecological potential for rain-fed farming is quite limited and the country is, in fact, already short of good agricultural land. High and medium potential lands with good to fair prospects for crop production and intensive livestock activities cover only 20 per cent of the land area. Production increases will depend on the possibilities of increasing yields per hectare, and of bringing remaining, often marginal, areas under cultivation (GOK 1986; 1994b).

The agricultural land is unevenly distributed over the country. The high and medium potential zones are found in the Central Highlands, the plateau adjoining Lake Victoria and the Ugandan border, and the very narrow strip near the Indian Ocean. These lands are bordered by semi-arid, low-potential belts. Here, the annual rainfall, with its high variability and seasonal nature, offers only limited opportunities for rain-fed agriculture. At present, almost the entire high and medium-potential zones are under cultivation. As a consequence, 
cultivation has extended into semi-arid areas (Kliest 1985). In the semi-arid zones, the rainfall pattern is characterized by low reliability and low amounts of precipitation. Rain-fed agriculture shows a seasonal cycle of cultivation and harvesting. Such conditions of seasonality, particularly in areas with only one rainy season, easily lead to fluctuations in food availability and even to food shortages. The topic of seasonality has received increasing attention in recent years. Although many African societies traditionally had to cope with seasonal food shortages, the effects of seasonality have possibly worsened as a consequence of increasing population pressure and the introduction of commercial cropping. Certain groups, such as small farmers, appear to be more vulnerable to the vagaries of the seasons than others.

In 1983, the Kenyan Ministry of Planning and National Development and the African Studies Centre, Leiden, started a programme of research projects to analyse current developments concerning food and nutrition in Kenya, notably regarding the interface between socio-economic factors, agriculture and nutrition. The first phase of the Food and Nutrition Studies Programme (FNSP) was partly funded by the Netherlands Government under the general agreement on technical cooperation with the Government of Kenya (for a recent review of the programme see Hoorweg 1993). One of the first studies consisted of a series of surveys in selected locations in Coast Province during 1985 and 1986. The general aim of the project was to study climatic seasonality and food security among rural populations in Kenya. Coast Province, more in particular Kwale and Kilifi Districts, were selected because of climatic characteristics, existing ecological variation, the relatively high incidence of childhood malnutrition and because the existing knowledge about nutritional conditions was scarce.

A series of reports was earlier completed under the title 'Seasonality in the Coastal Lowlands of Kenya, parts 1-5. ${ }^{*}$ These reports served as the primary means to make the statistical data available to the Kenyan and Netherlands Governments, and the reader is referred to them where more detailed information is needed. In November 1990, a seminar was convened with officers concerned with the social and economic development of the districts to discuss the draft reports and formulate recommendations (Foeken \& Hoorweg 1991). The present monograph comprises an edited compilation of the reports but without the detailed statistical data and detailed descriptions contained in the original reports. An effort has further been made to place the findings in a general framework with the help of an updated literature review and additional analysis, and to arrive at conclusions of a more general nature. The literature review is included in Chapters 2 and 3, and the socioeconomic profile of the study population is presented in Chapter 4. The sections on food consumption and nutritional status have been largely rewritten and are presented in Chapter 5 and Chapter 6 respectively. Chapter 7 contains the discussion and conclusions.

* Part 1: Research objectives and study design (Hoorweg, Kliest \& Niemeijer 1988);

Part 2: Introduction to seasonality (Foeken \& Hoorweg 1988);

Part 3: Socio-economic profile (Foeken, Leegwater, Niemeijer, Veerman \& Hoorweg 1989); and

Part 4/5: Food consumption and anthropometry (Niemeijer, Foeken \& Klaver 1991). Reports can be ordered free of charge from African Studies Centre, P.O.Box 9555, 2300 RB Leiden, Netherlands. 
The study covered a period of more than a year and a great number of people were involved. Without the assistance and support of these individuals and the institutions they represent the study could not have been realized. We wish to mention, firstly, the extensive support of the officers of the Ministry of Planning and National Development. The late J.O. Otieno, Chief Planning Officer of the Sectoral Planning Department, contributed greatly to the realization of the study, as did F.Z. Omoro and Mrs. L.I. Shitakha, successive heads of the Food and Nutrition Planning Unit. In Mombasa, the Provincial Planning Officer, P.B. Mjambili, gave invaluable assistance with the local introductions and the organization of logistics. He was later replaced by J. Echessa. We are also indebted to the District Development Officers in the two districts: Dr. K. Oigara, H. Ajwang and R.W. Machina, as well as the Division Officers, Chiefs and Assistant Chiefs in the different locations.

Our colleagues of the Central Bureau of Statistics, F.M. Munene and N. Mwasigwa, District Statistical Officers, assisted us greatly with the sample selection and the recruitment of assistants. We wish to mention in particular the CBS field supervisors J. Ngolo and G. Tumbo, who played an active role throughout with the supervision of field assistants. The team benefitted greatly from their long experience.

We are particularly grateful to the members of our office and field staff. Although the group experienced the usual ups and downs, it was a coherent and harmonious team. Miss P. Dzombo, Miss S. Ngala, Mrs. A. Kazungu, J.A. Odingo, B.O. Ajode, R.C. Chacha, J.K. Hamisi, M.A. Maalim, S.S. Masha, S.R. Mwaguni, I.M. Mwaropia, F.M. Nyundo, E.M. Pekeshe, L.S. Rasi, M. Salim and R.D. Washe formed a fine team and we regret that it had to be disbanded.

At various stages all our studies benefited from the comments of members of the FNSP Steering Committee, of whom we wish to mention in particular the late S. Akach (Central Bureau of Statistics), L. Wasonga (Office of the President), and Dr. G. Ruigu (Institute of Development Studies).

Many staff members of the African Studies Centre participated during different stages of the research. Marian Geuns and Ted Kliest were involved in the first stages of the study. Rudo Niemeijer was a member of the team throughout. Piet Leegwater participated in data analysis. Willem Veerman, who did much of the computer analysis, merits special mention because he managed to keep the data sets accessible and operational. At times he was assisted by Harold van Driel. They have all made important contributions, although the responsibility for this manuscript lies with the authors.

Finally, we wish to thank Mrs.N.Betlehem-de Vink for preparing the figures, Mrs.I.Rike for editing various texts, and Mr.K.Dorrepaal for his assistance with the production of the monograph. 


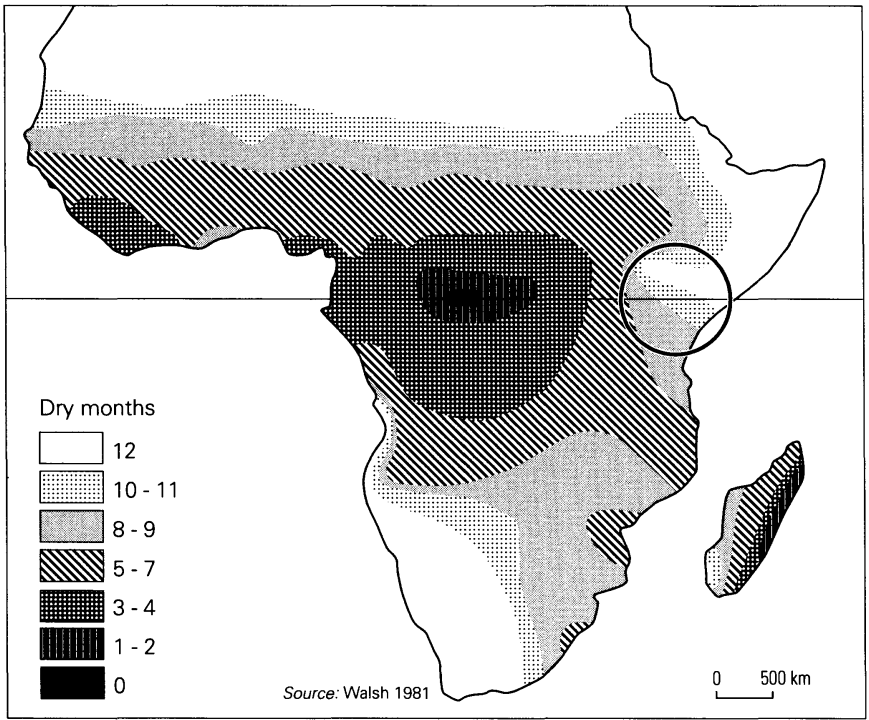

Map 1 Sub-Saharan Africa: Dry months per annum (Kenya in circle)

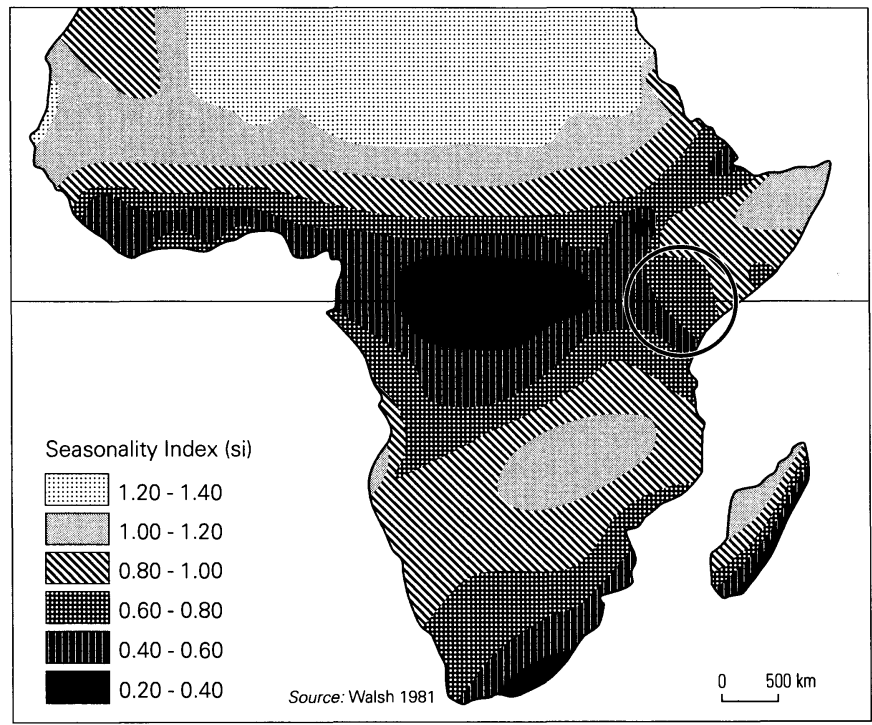

Map 2 Seasonality index for Sub-Saharan Africa (Kenya in circle) 


\section{Seasonality in Sub-Sahara Africa*}

\subsection{Introduction}

During the late thirties the first publications appeared drawing attention to the existence of a so-called 'hungry season' in many parts of rural Africa (Fortes \& Fortes 1936; Lynn 1937; Richards 1939). Twenty years later, an FAO report again noted that pre-harvest food shortage was a problem, particularly in the drier parts of tropical Africa (FAO 1958). The essential aspect of what nowadays is called 'seasonality' was recognized early on: rural people do not have enough to eat during the period that food is most needed, i.e. the period of intensive agricultural work. Over the years, separate studies have documented many seasonal dimensions of life in Third World countries: seasonal agricultural labour needs, differences in food supply and food availability, fluctuations in prices of crops and foodstuffs, variations in health and illnesses. The following description of an 'ideal seasonality scenario' gives an idea of the many different aspects of rural life that are involved:

The scenario starts with a tropical environment where a wet season follows a dry season, and where cultivation is practised. Towards the end of the dry season, food becomes scarcer, less varied and more expensive. The poor people, who may be landless or have small plots of land, experience food shortage more acutely than their less poor neighbours. Some migrate in search of work and food. Others un-

\footnotetext{
* This chapter is a revised and enlarged version of earlier text in Foeken \& Hoorweg (1988, 10-28).
} 
dertake non-agricultural activities near their homes in which the returns to labour are low. More work is involved in fetching water.

When the rains come, land must be prepared, and crops sown, transplanted and weeded. If animals are used for ploughing, they are weak after the dry season. Delays in cultivation reduce yields. For those with land, food supplies depend on the ability to work or to hire labour at this time. For those without land, work in the rains and at harvest often provides the highest wages of the year. This is the time of year when food is most needed for work, but it is also the hungry season when food is shortest and most expensive.

It is, too, a sick season when exposure to tropical diseases is at its greatest, when immunity is low, and when women are most likely to be in late pregnancy. So the rains bring crisis. Vulnerable to hunger, sickness and incapacity, poor people are undernourished and lose weight. (...) Stress is passed down to the weakest - women, children, old people and the indigent. Sometimes (...) an irreversible downward movement into deeper poverty occurs as assets are mortgaged or sold without hope of recovery. This is, then, a time when poor people are kept poor and a time when they become poorer.

With the harvest things improve. Grain prices are lower, a benefit to those who must buy food but a disadvantage to those small farmers who must sell their crops to repay debts or raise money for ceremonies. After the harvest, ceremonies, celebrations and marriages take place. Body weights recover. The dry season sets in. And then the cycle begins all over again. (Chambers 1981, 5)

It was generally assumed that there is a "widespread tendency for adverse factors to operate concurrently during the wet seasons (...which...) tend to hit the poorer people harder" (Chambers et al. 1979, 3). The last two decades the seasonality phenomenon has received considerable research attention and it has become evident that it is a far more complex issue than the existence of a hungry season alone. It has also become clear that the convincing picture sketched above is not often found in this unadulterated form because of the coping behaviours that people develop and other compensatory mechanisms. During the 1980s, a fairly large number of separate studies documented many seasonal dimensions of life in Third World countries. Several conferences and workshops on seasonality have been organized 1

This chapter discusses various aspects of seasonality and also tries to give a differentiated picture of seasonality in Sub-Sahara Africa. Each discussion of seasonality must necessarily start with climatic seasonality. 2 Other seasonal aspects, as they are derived from climatic seasonality, are described next. Then follows a discussion how people, affected by adverse seasonal conditions, tend to cope with these problems.

\subsection{Climatic Seasonality and the Agrarian Cycle}

Plants need three elements for growth: solar radiation, water and nutrients. Solar radiation, which is the ultimate source of energy for all plants, is not a limiting factor in the tropics. Neither are soil nutrients, despite the fact that tropical soils tend not to be very fertile because of the low humus content; satisfactory yields are generally possible. The main limiting factor, then, is rainfall, or more accurately: the availability of soil moisture. The quantity of moisture in the soil determines the growing season, the time when loss of moisture through evaporation and transpiration is met by sufficient rainfall. 
Thus, whereas in the temperate regions of the world seasons are primarily defined by fluctuations in temperature and sunshine, in the tropics precipitation determines the nature of the seasons. On the basis of rainfall distribution throughout the year, Walsh (1981) distinguishes three types of tropical climates:

a) Climates with no real dry season. In Africa, regions with these climates are found around the equator (and in eastern Madagascar), with the exception of East Africa;

b) Climates with two rainy and two dry seasons. These so-called 'bimodal' climates are concentrated in two zones, one north and one south of the equatorial zone, although they meet in East Africa;

c) Climates with one wet and one dry season. These 'unimodal' climates form a further zone in the north (up to the Sahara) and in the south, up to the South-African deserts in the west and the temperate regimes in the south-east.

Until recently, there was the misapprehension that no seasonality exists in the first type of climates. Studies among ethnic groups in the Central African rain forests, however, have revealed that in fact there is a relatively dry season or even two. Moreover, seasonal fluctuations in food consumption have been observed, as well as significant weight losses during the rains (Bailey \& Peacock 1988; Pagezy 1988).

The distinction between bimodal and unimodal climatic regimes is an important one. In general, people living in a bimodal climate experience less seasonal stress than people living in regions with only one rainy season. In the former case, two annual harvests will often be possible, reducing not only the time-gap between harvests, but also reducing storage problems and food shortages. Schofield (1974), using survey material from 25 African villages, noted that in villages with a unimodal climate, caloric requirements were met for 100 per cent during the dry season but for less than 90 per cent in the wet season. In the 10 villages with a bimodal climate no such difference was found.

The bimodal-unimodal distinction is rather crude. It reflects the existence of one or two rainy season(s) and one or two dry season(s) in an average year. However, normal years rarely occur and the distinction does not allow for fluctuations in rainfall other than the wet/dry season distinction. This brings us to three types of rainfall fluctuation that can be recognised.

a) Seasonal variability. This refers to the fluctuations of rainfall within one year. It is usually measured in one of two ways. The first method is concerned with absolute seasonality: counting the number of 'dry months' per annum, with a dry month defined as a month with insufficient rainfall to meet the potential needs of plants. In Map 1 (p.4), 4 inch $(102 \mathrm{~mm})$ is used as cut-off point showing the number of dry months per annum for different parts of Sub-Sahara Africa. Relative seasonality, on the other hand, refers to the relative contrast between the amounts of rain at different times of the year. An index has been calculated to reflect this type of seasonality: the sum of the absolute deviations of mean monthly rainfall from the overall monthly mean, divided by mean annual rainfall. This index ranges from 0.00 if all months have equal amounts of rain, to 1.83 if all rain is concentrated in a single month (in reality, these extremes do not occur). Map 2 (p.4) shows the spatial distribution of this seasonality index, as calculated for Sub-Sahara Africa. 
b) Interannual and intermonthly variability. The former type of variability concerns the yearly deviation from the average annual rainfall. In semi-arid climates this variability can amount to 30 per cent or more. In really dry climates the figure can even rise to more than 100 per cent. Equally important for the timing of agricultural activities if not more so is the monthly reliability of rainfall, i.e. the deviation from the mean monthly rainfall. Will there be enough rainfall to start planting? Will the rains, necessary for the ripening of the crops, be in time? And if so, will these, again, be sufficient? According to Walsh (1981), if mean annual rainfall is low, variation - yearly and monthly - tends to be high as well, so that seasonality is inversely related to the annual level of precipitation. The more marked the seasonality of rainfall, the less reliable the rainfall during the rainy season, which is why three out of ten harvests are poor or fail completely for millions of people living in semiarid areas.

Because of the interannual variability of rainfall, it is difficult to draw conclusions about the fluctuations of food supply, food consumption and nutritional condition on the basis of a one-year's study. An example from northern Cameroon may illustrate this. In 1976, there was no rainy season food shortage observed among the Massa and Mussey. Four years later, however, a serious shortage period was experienced, resulting in substantial weight losses of both men and women (Garine \& Koppert 1988). The difference was to be explained by the very good harvest of 1976 , made possible by rains that were both sufficient and well distributed.

c) Spatial variability. Although somewhat neglected in the literature, precipitation can differ greatly over short distances and crop yields can vary substantially in nearby places. Again, if mean annual rainfall is low, spatial variability tends to be high. For instance, the distribution of rainfall in a relatively dry region in Mali was found to be highly localised. This factor, together with differences in soils and access to fertilizer results in considerable differences in harvests between neighbouring villages (Toulmin 1986).

The growing season in systems of rain-fed agriculture depends on, first, the quantity and distribution of rainfall and, second, the rate of moisture loss. The rate of moisture loss is dependent on soil characteristics, the type of crops cultivated and the methods of cultivation. Soil characteristics like texture, structure and porosity determine the infiltration capacity and storage capacity of the soil. Usually, the greater the infiltration capacity (e.g. of sandy soils), the less the storage capacity, but this can be overcome with cultivation methods that conserve soil moisture, for instance by manuring or by mulching.

As a consequence of the moisture needs of plants during their growing cycle, normal or even above-normal rainfall as such is not sufficient for a good harvest. Equally important is the distribution of the rainfall over the months. For instance, if the late rainfall necessary for the ripening of the crops is insufficient, the harvest will still be poor, however good the first rains may have been. In regions with two rainy seasons, harvest failures are less likely to occur than in unimodal climatic regimes. Moreover, a much wider range of different crops can usually be cultivated, which also tends to reduce the risks of poor harvests. The less the annual rainfall, the shorter the rainy season, the shorter also the agricultural cycle, and the more seasonally concentrated the harvest will be. 
The potential of agriculture falls steadily as the number of dry months in the year increases (Bayliss-Smith 1981) and this applies not only to cultivators but also to pastoralists in regions where rainfall is insufficient for rain-fed agriculture.

Climatic seasonality and the ensuing agricultural periodicity affect many aspects of life. Some of these can be regarded as effects, notably variations in labour needs, food consumption, nutritional status, health, vital events as well as various aspects of social life. Others have to be regarded as coping mechanisms, either of a preventive or curative nature. Effects and coping mechanisms are separately discussed in the following sections.

\subsection{Effects of Climatic Seasonality}

\section{Labour}

Seasonal concentration of the agricultural production cycle firstly implies seasonal concentration of productive labour, although seasonal labour for crop cultivation differs from that for livestock keeping. The main cultivation activities are land preparation, planting, weeding (often in two rounds) and harvesting. The precise timing of the activities, however, depends - apart from the moment the first showers actually arrive - on the ecological characteristics of the area concerned and on the kinds of crops that are cultivated. For instance, harvesting in certain valley areas in eastern Zambia occurs more than one month earlier than on the adjacent plateau, because of the higher temperatures in the valleys. Planting operations of the three main food crops in this region - maize, groundnuts and sweet potato follow each other closely during the period from November to January. At the same time, planting of cotton - the main cash crop in the region - can be spread evenly over this period (Kumar 1985). Nevertheless, overlap of some activities is usually inevitable:

(...) the peak agricultural activity in the African tropics tends to be in the middle of the wet season. The single most demanding operation is usually weeding. It is this task, combined with harvesting the early food crop and perhaps sowing a late crop, that causes the midseason peak, particularly in the moist savanna region (Cleave 1974, 190).

In many parts of Africa, there is in fact a shortage of labour during these periods, the more so because school holidays usually do not coincide with peak labour seasons, as shown for six countries in East and Southern Africa. Generally, school holidays are national and do not take account of local conditions. Poorer farmers, who can not afford to hire labour, are thus forced to keep their children at home when their labour is needed (Fowler 1982).

Livestock herding comprises three major tasks: supervising (or pasturing), watering and milking. Of these, supervising and milking do not need much labour. Watering, on the other hand, "is an arduous, energy-consuming task (...) for which peak labour requirements occur in the dry season (...)" (Swift 1981, 84). As surface water dries up, wells have to be dug in dry riverbeds and have to be maintained. With the duration of the dry season wells have to be dug deeper and deeper while at the same time more and more cattle return from outlying areas where standing water is exhausted. This means that long dis- 
tances have to be covered during times of great heat; on arrival at the wells the herdsmen have to hoist water into the watering troughs, which is generally regarded as back-breaking work (White 1986).

The labour bottlenecks that exist in crop cultivation and livestock herding therefore tend to be seasonal. In the former case peak labour requirements occur during the wet season; in the latter case during the dry season. Where the two agricultural systems exist together, they may function supplementarily, at least in terms of labour requirements. An example can be found in Central Bagamoyo district, Tanzania, where pastoralists meet the labour shortages in the dry season by employing cultivators as herdsmen (Ndagala 1981). The reverse situation, pastoralists employed by cultivators during the wet season, does not seem to exist, however.

Agricultural labour may be concentrated in a relatively short period of the year, the amount of physical effort - expressed in terms of energy expenditure - is even more so. This is caused by the fact that certain types of labour are more strenuous than others. Clearing the land and weeding the fields are well-known examples of activities with a high level of energy expenditure. The real labour peak among a group of rural Gambian women, for instance, was confined to the months of June and July only, i.e. at the start of the rainy season when the fields had to be cleared and digging had to be done (Lawrence $e t$ al. 1989). The average energy expenditure level during these months was considerably higher than the energy intake level.

Traditionally, many of the tasks connected with crop cultivation or livestock herding were more or less allocated by gender. Men were expected to do the clearing and preparation of the land and to assist with the planting, women were responsible for the weeding, while both sexes usually participated in harvesting; with considerable variation according to the type of crop and the region of Africa. Another division of labour has developed in respect of the cultivation of cash crops. In general, men occupy themselves mainly with cash crop production, while women are given the responsibility for food crops. Nowadays, in many parts of Africa, women are expected to grow most of the family's food. Similar divisions tend to occur among pastoralists, where women are often responsible for milking, dairy processing and selling, the care of young animals and whatever cultivation occurs, while men are responsible for the watering and grazing of livestock. The gender division of labour therefore also means that peak labour demands may fall at different times of the year for the sexes (Ensminger 1985).

However, the gender division of labour is breaking down rapidly and proving flexible in case of need. In many areas of Kenya, for example, but elsewhere in Africa as well, women have to fill in the labour gaps that inevitably occur because of the growing need for off-farm employment of the men. In fact, many of the women in well-off households tend to function as farm managers in the absence of their husbands (Veldhuis 1981; Hoorweg \& Niemeijer 1989). Most agricultural tasks are now performed by men and women alike, with only a few specialized activities reserved for either sex as further examples from Machakos, Embu and Nyeri Districts demonstrate (Cleave 1974). 
True as the above may be, it refers only to the division of agrarian labour. There is a whole range of domestic tasks and these still tend to be female activities. House cleaning, food preparation, collection of water and firewood, and child care are time and energy consuming. Moreover, these are year-round activities and some of them are also seasonally dependent (Palmer 1981). It means that an increase in agricultural work often goes at the cost of the domestic activities. This may have consequences in the sphere of food consumption, nutrition and health which will be discussed in the next section.

\section{Food consumption and nutritional status}

Seasonality in crop production implies fluctuations in food supply and food availability. After the harvest, i.e. during the dry season, there is usually enough food for some time. But during the following wet season food stocks are slowly depleted, with food becoming more and more scarce during the few months before the next harvest. This is especially the case in unimodal climates. Kumar (1985) reported that in Zambia by the end of the planting season, about 40 per cent of the households had maize stocks remaining, 15-20 per cent of the households had sorghum and groundnuts, and almost no one had sweet potatoes left. At the time of harvesting, only 10 per cent of the households still had any maize in stock. But even in bimodal climates food stocks are usually at a minimum level by the end of the rains. In central Kenya, for instance, less than one-sixth of the households had any food items left in store by the end of the short rains (Onchere \& Slooff 1981), a figure that differs little from that for the unimodal Zambian situation.

In pastoral societies, milk forms the staple diet, although it is never the only food source. Milk production depends on the breeding cycle of the female animals, which means that milk supply is largest during the rainy season. This is the period that fresh milk is the daily food. A negative side-effect is the competition between man and suckling animals, as the latter can only drink the milk that remains after the mother animals have been milked for human consumption, which may lead to higher mortality rates among the calves, in particular in the smaller herds belonging to the poorer stock breeders (Bernus 1988). Although the production cycle of milk also depends on the kind of animals, the fact remains that milk production is at its lowest during the dry season.

For cultivators food shortages therefore tend to be highest during the wet season and just before the harvest; this is also the period during which hard work is required. Similarly for pastoralists, food availability is lowest during the dry season, which for them is the season in which peak labour requirements occur.

The amounts of food held in stock, however, do not offer a full picture of the household food situation, because of the possibilities of food supply through other channels: purchases and gifts, not to mention famine relief. As regards purchases of food, prices tend to be relatively high during the pre-harvest period when supply at the market is low. In Burkina Faso, prices - producer as well consumer prices - showed increases of fifty per cent from one season to another (Ellsworth \& Shapiro 1989). As the consumption of the poor is especially price-responsive, high pre-harvest market food prices are a serious problem for them (Sahn \& Delgado 1989). 
It was already mentioned that a review of nutrition surveys in different countries revealed that in villages with a unimodal rainy season, the percentage fulfillment of caloric requirements was 100 per cent in the dry season and 88 per cent during the wet season (Schofield 1974). It is not surprising that there is further variation as well, notably between families of different socio-economic levels. Reardon \& Matlon (1989) studied two communities in Burkina Faso: a mainly pastoralist community in the Sahel-zone (Woure) and a village of cultivators in the slightly less drier Sudan Savanna-zone (Kolbila). There was little difference between the caloric intake of the 'poor' in Woure compared with the 'poor' in Kolbila. The intake of the 'middle' and 'rich' strata in Woure was much higher than in Kolbila. Consequently, in pastoralist Woure there was a large difference of caloric intake between the 'poor' on the one hand and the 'middle' and 'rich' on the other. Seasonal fluctuations in caloric intake were by far the largest among the 'poor' and during the hot season their energy intake was far below standard. In Kolbila, on the other hand, it was only the 'rich' that enjoyed substantially higher intakes and the 'poor' and the 'middle' groups showed the same strong seasonal fluctuations in calorie intake as the 'poor' in Woure, be it during the rainy season. The importance of differences in socio-economic class will be discussed further in the section on coping mechanisms.

In addition to the variations by social class, there are strong indications that the intrahousehold distribution of food is uneven (Haaga \& Mason 1987), also in times of stress:

.....in relation to their requirement, adults (excluding pregnant and lactating females) consume more than any other age group. Adult males fulfilled calorie and protein requirements at 101 and 231 per cent respectively, while adult females achieved lower levels of 96 and 136 per cent. Pre-school children fulfilled calorie requirements at a much lower level ( 80 per cent) than the per caput figure (94 per cent) but the differences were not significant (Schofield 1974, 25).

Since then, several other studies have confirmed this picture: small children and pregnant and lactating women are the most vulnerable groups during periods of intensive labour and food shortages (Kigutha 1994). For instance, in a Gambian village pregnant and lactating women had energy intakes considerably below the normally accepted range, and this effect was most marked during the rainy season. The deficit was even greater if the high energy expenditure associated with farming activities during that period was taken into account. As a consequence, weight fluctuations of these women showed the same seasonal pattern: "pregnant and lactating women lost weight during the middle of the rainy season, though the former group at least would have been expected to gain" (Rowland et al. 1981, 170). Geuns, Niemeijer \& Hoorweg (1991) found that during the lean season in rural western Kenya the energy intake of children in a rice irrigation scheme was about twenty per cent below requirements and relatively below that of the adults. In Malawi, it was also observed that in general, children and infants had the lowest and adult men the highest energy intake, particularly when food supplies were lowest (Wheeler \& Abdullah 1988). Similar patterns have been noted in pastoral societies. For instance, Loutan (1985) found that children of 1-5 years of age actually lost weight at the end of the dry season, i.e. the season of food shortage. Garine \& Harrison $(1988$ b, 472) stress that although "the differential access to 
food by various biological categories (...) is a fact, [it is] a rarely investigated field". They conclude from recent observations that women "do not appear to be as disadvantaged as is commonly supposed".

It is not surprising, then, that birth weights and breast milk yields vary with season as well. Birth weights tend to be higher for children born in the dry season, while breast milk yields are lowest at the end of the rainy season (Rowland et al. 1981; Onchere \& Slooff 1981). Children born in the beginning of the wet period show slower growth progress than children born in the beginning of the dry season, at least during the first six months of life. From then on, breast milk is supplemented with other food from the recent harvest, so that from that age on babies born in the beginning of the wet season may be better off. More specifically, Bantje \& Niemeijer (1984) found in a rural area in Tanzania that birth weight fell by about 60 grams in the course of the rainy season. Moreover, deviations from average rainfall showed a positive correlation with birth weight but only in the months when rainfall was critical for food crop production. In Gambia the season of birth as well as age dictated the average pattern of weight gain during the first year of life. Thereafter, average weights were unusually good during the dry months and poor during the wet months (McGregor et al. 1968).

There are not many studies that include an analysis of variations in adult weight by season. One concerns eastern Zambia (Kumar 1985), in which it was found that during the wet season the weight-for-height ratios for adults were at a minimum, rising from the beginning of the dry season and reaching their highest level just before the next wet season. Longhurst \& Payne (1981) mention two other surveys, one in Gambia and one in Ghana, where the same seasonal pattern in body weight was found. Another study in Gambia revealed weight losses of almost five kilograms among rural women during the rainy season (Lawrence et al. 1989). In the pastoral society of the WoDaaBe in Niger, adult weights fell sharply during the hot dry season, of men and women alike (Loutan 1985). More recently, Schultink (1991) found, in two Beninese villages, one with a bimodal and one with a unimodal climate, body weight decreases of about 2.5 and 6.0 per cent, or one and three kilograms, respectively.

In conclusion, Figure 1 shows a hypothetical diagram of the seasonal fluctuations of energy needs, energy intakes and body weights in two distinct climatic regimes: a unimodal regime (with one rainy season from March to June) and a bimodal regime (with a long rainy season from March to June and a short rainy season in October-November). Figure (a) shows the unimodal scenario. Variations in energy requirements are mainly caused by the fluctuating labour demands in agriculture and are reflected by the $e r$-line. 

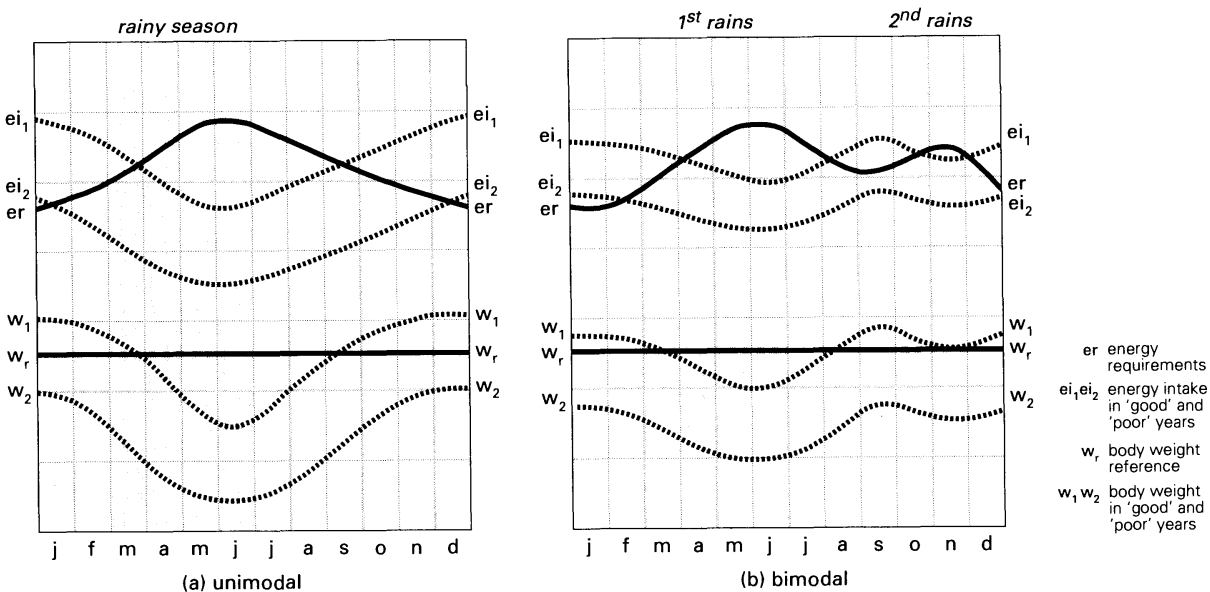

Figure 1

Hypothetical fluctuations of energy requirements, energy intake and body weight in unimodal and bimodal tropical climates

According to the 'classical' seasonality scenario, the energy intake (the $e i$-line) shows the opposite fluctuation. Two intake levels are shown. The $e i_{1}$-curve is the ideal type, with energy requirements and actual energy intake being in balance over the year. The weight of the food producers $\left(w_{l}\right)$ fluctuates around the reference weight $\left(w_{r}\right)$ for that particular group in that particular area. In relatively poor years, the nutritional condition is likely to be below the reference level the whole year through and reaches a critical minimum during the periods of peak labour requirements. The $e i_{2}$-line and the accompanying weight fluctuation $\left(w_{2}\right)$ are reflections of such a situation. Figure (b) shows a bimodal situation in which there are second (short) rains that are of less magnitude and involve less cultivation labour. 3

\section{Health}

Many authors stress the prevalence of certain diseases during particular seasons. 4 Respiratory tract diseases like pneumonia and bronchitis as well as measles occur significantly more often during the dry season in the Bagamoyo region in Tanzania (Goetz 1981). The same is reported for the Zaria region in Nigeria, where serious epidemics of cerebrospinal meningitis occur each year at the end of the dry season (Tomkins 1981). Typical wet season diseases are, according to these two writers, gastroenteritis (diarrhoea, vomiting), guinea-worm, malaria, anaemia, typhoid and protein-energy malnutrition. Of these, malaria, diarrhoeal diseases and guinea-worm show the most marked seasonal patterns. And although all age groups are affected, "the brunt of the first two falls upon infants" (Bradley 1981, 130). This is the more serious because gastroenteritis and malaria have negative effects on the growth of children. The same seasonal pattern occurs with severe forms of protein-energy malnutrition (PEM). Tomkins (1981) reported a peak of admissions to hospital for clinically severe PEM during the rainy season in Zaria. 
In pastoral societies, each of the four seasons brings certain diseases. Many individuals are often feverish during the wet season, due to malaria. During the cold season, the temperature during the nights can be close to $0^{\circ} \mathrm{C}$, resulting in colds and bronchitis. The following dry season shows an increase of eye infections and cerebrospinal meningitis. Finally, the warm season is the most tiring for men and animals, while undernutrition makes people vulnerable to disease (Bernus 1988).

In general, the wet season is the time when the health situation is at its worst. But it is also the season of high labour requirements and of food scarcity. Malnutrition is one of the main causes of the rise in morbidity during the rainy season, because it makes people more susceptible to infections. There are other factors, like rainfall and temperature, that also determine the seasonal cycles of diseases. Many insect vectors depend on surface water for breeding, and vector-borne diseases like malaria and guinea-worm prevail during the wet season (and, to a lesser extent, schistosomiasis and sleeping sickness). Still other causes are to be found in seasonal variations in behaviour. Close physical contact between people indoors during cold nights may facilitate the spread of some respiratory infections 5

What has been said about morbidity applies, to a certain extent, to mortality as well. Young children from poor households can be considered the most vulnerable group (Dyson \& Crook 1981), especially during the wet season. Regarding diarrhoeal diseases, Onchere \& Slooff (1981) found that 80 percent of deaths of under-fives in Machakos district, Kenya, occurred during the long rains, most before the age of one year. Other causes of death, however, were fairly evenly spread throughout the year.

Schofield (1974) argues that children born in the first half of the wet season are the most vulnerable, as birth weights at this time of the year are low and breast-feeding and child care are inadequate due to the peak in agricultural labour by women in the wet season. A similar, though seasonally reverse finding, comes from Eerenbeemt (1985). In the pastoral Fulani society of central Mali, children born in early March, i.e. the beginning of the hot dry season, appear to have a higher risk of dying, especially during the first year of life. Children born in June, i.e. the beginning of the wet season, when food is abundant and labour requirements are relatively light, had significantly greater survival chances, up to the age of five.

\section{Social activities}

Seasonality also has a profound impact on social relationships within African rural communities. Some of these will be discussed in the section on coping mechanisms, for instance where labour and debt relationships between poor and rich households are concerned. Another example is the wide range of redistributive mechanisms that serve to meet the adverse effects of climatic fluctuations.

Other social events that show seasonal variations are weddings, communal festivities and the activities of certain social organisations during specific seasons. In central Mali, "most marriages take place in the period after the harvest when the hard work is over and life temporarily slows down" (Eerenbeemt 1985, 89). This may also explain the seasonal peak in births after the rainy season, which indicates a higher conception rate in January at 
the end of the cold period. Among the Onicha Ibo marriages were rarely contracted during the hunger months, especially the last two months before harvest. Moreover, during the latter period "there are no public rituals involving feasting and extensive hospitality" (Ogbu 1973, 323). Most religious activities take place at the end of the new yam month.

Relatively little attention has been given to the seasonal dimensions of rural social organisations in the existing literature. Fortmann $(1985,384)$ has suggested a continuum of rural social organisations related to the seasons. At the one end 'continuous organisations' which function on a year-round basis. The other end is formed by 'seasonal-functional organisations', which "operate at a specific time of the year and then disappear until the following seasons. Such organisations are typically tied to some part of the agricultural production cycle." Examples are informal groups of women, who help each other with weeding or harvesting to disband afterwards (Jiggins 1986); fencing groups, which erect and maintain fences when the need for agricultural labour is less pressing; and so-called damgroups consisting of farmers who agreed to maintain small dams for livestock and regulate their use, activities that take place during the dry season.

\subsection{Preventing Seasonal Stress}

People adjust to seasonal stress in many ways, showing diverse adaptations in the agronomic, nutritional, economic, demographic and social spheres. There comes a stage, however, when ordinary measures may prove insufficient and when food shortages occur. Most writers have concentrated on the ways in which people cope with the more severe forms of seasonal stress, as in the case of hunger, famine and other desperate circumstances ${ }^{6}$ Different authors use different classifications in order to get some grip on the diversity of coping mechanisms. For instance, Longhurst (1986b) uses a time perspective, distinguishing seasonal and famine coping strategies. Different food strategies have been described from an anthropological perspective: "the different routes by which households acquire food (...) and extend food supply" (Messer 1989, 158). Different types of 'survival' strategies have also been described (Gill 1991). Finally, indigenous and introduced solutions to food stress have been distinguished (Moris 1989). A useful distinction is that between measures to prevent seasonal stress and measures to meet actual stress. In the first case we are dealing with more or less structural strategies, in the second case with famine-related responses, although the latter are often extensions of the former and it is not always easy to draw a clear line between them 7 The potential measures to prevent seasonal stress are reviewed below under three headings: food production, food purchases and redistribution of resources.

\section{Food production}

Possibilities for preventing seasonal stress lie, first of all, in agricultural practices and efficient food storage. The importance of food storage and food inventories are often mentioned but have only recently started to receive more research attention (Parisier 1982; 
Some, Maritim \& Faraj 1993). Most attention until now has been given to improvements in agricultural practices to secure sufficient food production and reduce the risk of harvest failures. Many of these practices date back a long time. A first adaptation consists of cultivation in different ecological zones, if land is available. Dietz (1990) describes two examples from West-Pokot, Kenya, where polygamous men try to marry wives from different ecological zones (altitudes), or where one nuclear household tries to obtain fields at different altitudes. Both strategies are aimed at having a 'stretched harvest season'.

A second adaptation concerns the choice of crops. Mixed cropping is practiced all over Africa, although the arrangements of crops in mixtures varies considerably, even among farmers in the same location. Examples are the combinations of maize and cassava, maize and beans, and sorghum and millet. Millet has a shorter maturation period than sorghum, but is a lower yielding crop. Early maturing crops can be of particular importance to the poorer groups because it shortens the length of the hungry season. Another advantage is that it reduces labour bottlenecks. Many farmers, furthermore, cultivate some cash-crops which are drought-resistant (cotton, groundnuts) in order to obtain some money that can be used to buy food (amongst other things) during the next lean season. Secondary crops, moreover, often form an important supplement of the staple diet. Four types of secondary crops have been distinguished in this respect:

a) Gathered crops, including wild vegetables occasionally cultivated (...). In a seasonal (...) context, such crops are important as relishes and salads (...).

b) Crops mixed into fields of staples, such as legumes, pumpkins and melons (...).

In good years they may not be harvested, and are eaten as snacks in the fields (...).

c) Cultivated vegetables in home gardens near the compound (...). Such vegetables, being intensively watered and manured, can mature early and have a seasonal role (...).

d) Non-staple root crops grown as a contingency reserve and which do eventually get harvested (...).

(Longhurst 1986b, 29).

A fifth type of crop can be added to this list. Treecrops, such as fruits, nuts, seeds and berries, can be harvested during the dry season or the whole year round, and can serve as a fall-back in bad years and during famines. "Trees in many parts of the developing world have traditionally formed the basis of counter-seasonal strategies..." (Gill 1991, 116).

Special reference is often made to the importance of cassava, particularly in Africa, where it is the largest source of food energy in the continent. Although in many areas cassava is regarded only as a famine crop, the crop is potentially of great counter-seasonal value: it is rich in calories (producing more energy output per unit of energy input than food grains), it grows well in relatively poor soils, it requires relatively little labour input, and it can be left in the ground for one-and-a-half to two years (Gill 1991). The Oto and Twa women in the Lake Tumba region in Zairre generally see to it that three cassava plantations are at different phases of growth, so that the leaves from the young plants and the tubers can be harvested the whole year through (Pagezy 1988).

The choice of cultivation methods offers a third adaptive possibility for farmers. This can range from simple measures like reducing the distances between plants, the cultivation 
of entirely new crops, small changes in technology, to a more radical solution to overcome climatic seasonal stress: irrigation if water is available.

A fourth choice concerns the possibility of mixed farming, i.e. breeding livestock in addition to crop cultivation. Dairy products not only offer a good supplement to the daily diet but animals can serve as insurance against bad times as well. When food is short, livestock can either be slaughtered or sold in order to buy food.

In pastoralist societies entirely different agronomic mechanisms exist to prevent seasonal stress. Sahelian pastoralists control the breeding of their camels, cattle, sheep and goats in such a way that the lactation periods of the different species of animals are spread as much as possible over the year. In this way, the Kel Adrar Twareg of north Mali spread their milk supply throughout the year, as far as the extreme climatic seasonality allows, although it appears to be impossible to accomplish this completely. This system is only possible if herds consist of several species of animals (Swift 1981) ${ }^{8}$

\section{Food purchases}

Commercialisation of agriculture - notably the sale of cash crops, selling of livestock, and the sale of farm products - can potentially provide the means for a successful adaptation to seasonality apart from their other economic functions. That this is not always the case, is self-evident. Lump expenditures for school fees, weddings and funerals often mean that the money from these sources is only available at certain times of the year, but not for the purchase of food during the lean season. Moreover, selling and buying prices often vary in such a way that people sometimes are forced to sell certain food crops at low prices, only to buy the same foods back at much higher prices later on.

Employment can also serve to minimise the risks of climatic seasonality. Three kinds of income earning are generally open to rural households: home industry, trading activities, and wage labour. In general, people are quite ready to seize any (local) opportunity in the productive or trading sphere. These can be farm-related, like the processing and selling of agricultural products (leather, weaving products) or directed towards the exploitation of natural resources. Examples of the latter are hunting, fishing, firewood-cutting, selling of charcoal, selling of craft products made of grass and wood, etc. All these activities can be regarded as sideline activities in order to have some sort of income beside the main occupation of farming. Apart from these, there is a group for whom the situation is reversed: owners of shops and cafes, as well as people who are in the trading business on a more professional basis and who often cultivate as well, although one cannot speak of adaptive behaviour regarding seasonal stress in this case. All depends on the scale of business compared with the farming activities.

Wage labour is another option open to small farmers suffering from seasonal incertitudes. If this occurs intermittently, it can be considered a measure to prevent the adverse effects of seasonality by securing an income from which food can be purchased. The most extreme form is permanent migration by the head of the household for employment purposes, leaving his family behind. Again, it is questionable whether this should be regarded 
as coping with seasonality, although it is certainly part of the survival strategy of a household.

In some parts of Africa, seasonal labour migration was (and still is) an important feature. Many men (but also women) leave their home areas during the lean season in order to find work elsewhere. One of the best described examples comes from Sokoto (Nigeria), where during the dry season - which is very dry and very hot - Hausa farmers as well as agricultural labourers migrate southwards to the coast, the former for selling their cash crops, the latter to find all kinds of jobs (Swindell 1984).

Migration of men can have negative effects on the work-load of women, although this seems to be more associated with the longer-term circulation than with the truly seasonal labour migration (Rempel 1981). In a study of the effects of migration of men on the position of their wives who stayed behind on the farms in Machakos District, it was reported that the work-load of these women had considerably increased: apart from their 'traditional' tasks in the household and in food cultivation they had to take care of the coffee cultivation as well and they generally found it difficult to cope with so many tasks (Veldhuis 1981).

The relationship between cash income on the one hand and household food security on the other cannot be understood without giving attention to the gender aspect of income earning activities. Men and women not only differ regarding the access to these activities but also in the ways the income is spent. Men usually claim the larger sums of money from the sale of cash crops and wage employment and they are usually expected to take care of the larger household expenses such as school fees, housing, clothing and sometimes bulk food purchases (Hoorweg \& Niemeijer 1989). Income-earning activities of women are mostly home-based, for the simple reason that the woman, and certainly when she is the head of the house, cannot leave the homestead because of her responsibilities for food production and domestic work 9 This implies that most cash has to be derived from the sales of agricultural products and/or some kind of home industry. As a result, women's cash incomes are usually rather modest and quite seasonal (Guyer 1989). Because women are responsible for food provisioning, usually a large part (certainly compared with the men's incomes) of their earnings is spent on food.

Income earning has undoubtedly become an important strategy for the household to secure itself of food throughout the year. That does not mean, however, that the household will or can aspire a food intake level equal to the objective requirements. Among the Massa and Mussey of northern Cameroon, for instance,

money is considered too scarce to be spent on such trivial items as food. Besides, food appears traditionally as something which should be produced at family level (...). It ranks much lower in priority than the complex prestige circuits of bridewealth (...), prestige fattening cures, cattle lending, and, more recently, possession of modern items (...) and drinking (Garine \& Koppert 1988, 240). 


\section{Redistribution of resources}

Adaptations of a social and economic nature may be equally important. In many African societies, there exist networks of social relations of a redistributive nature. These networks serve as a kind of insurance against outright poverty and they take several forms. In Muslim societies, the grain tithe brings about immediate post-harvest distribution of foodgrain production (Simmons 1981). Patron-client relationships are common in Muslim societies in which men provide regular farm labour for rich farmers in return for wages and food. These patrons are expected to give extra support in case of famine. A third kind of network consists of the complex gift-giving relationships between men and between women. The gift, in this case, is an investment that serves "both as a means of gaining prestige and as a security to guarantee subsistence should hard times arise" (Watts 1981, 202).

Similarly, in Sahelian pastoralist societies cattle-borrowing occurs widely among households. Among the Kel Adrar Twareg of north Mali, a network exists of

traditional non-market transactions with animals which serves to mitigate seasonal or sudden unexpected food shortages. If a household does not have enough animals to provide a sufficient milk supply, it can go to a richer household and borrow animals according to one of a number of standard agreements, which include the seasonal loan of a lactating animal. In minor seasonal or other crises, these transactions serve as redistributive mechanisms by which the rich help the poor (Swift 1981, 86).

From studies in the rain forests of Central Africa, the long-standing relationships between the originally hunting/gathering Pygmies and the agriculturalist non-Pygmy groups appear to be crucial for the food security of both groups. The former perform agricultural labour during peak periods for the latter, in return for food (Bailey \& Peacock 1988). Bahuchet (1988) also mentions the dependency of the Aka Pygmies on non-Pygmy agriculturalists, while a comparable situation exists among the Twa Pygmies and the Oto in Zaire (Pagezy 1988). Food sharing is another mechanism in hunting/gathering societies in order to secure that all members of a group have sufficient to eat. Reportedly, among the Aka each woman who has cooked a meal gives a portion to every hut in the camp.

With the onset of colonial rule, however, the rural communities were increasingly incorporated into the national economies. Growing monetisation (taxes) and commodity trade created new forms of dependence (middlemen), and the traditional social systems came under pressure. As a result, in many societies, social and demographic coping mechanisms broke down or were adjusted to the new circumstances. This does not automatically mean that rural people are hit harder by seasonality nowadays. For instance, among the Massa and Mussey in northern Cameroon, the food situation is better than in the past, even though the traditional coping mechanisms in the social sphere have disappeared (Garine \& Koppert 1988). A shift has taken place to economic adaptations. Or "money income tends to become the major explanatory variable of feeding behaviour" (Garine \& Harrison 1988b, 474). 


\subsection{Acute Seasonal Stress}

Despite all the measures taken in the preventive sphere, seasonal stress may be felt, i.e. food shortage may occur. Many ways are open to the household to cope with such a situation. There is some consensus about a hierarchy of curative coping mechanisms, in the sense that as the stress becomes worse, more far-reaching measures will be necessary (Watts 1988; Hartog \& Brouwer 1990).

\section{Food consumption}

Once the adaptive mechanisms to prevent seasonal stress are exhausted and food shortages do occur, the range of possible adaptations is narrowed. There remain, of course, possible adaptations in respect of food consumption, notably the consumption of alternative foods and the rationing of daily meals.

Certain foods are usually designated as 'famine foods'. These are foods growing wild such as vegetables, nuts, berries and parts of trees. In normal times they are consumed only by the very poor and their consumption is usually a sign of shame. The seasonality of gathering and hunting is not only determined by scarcity of agricultural food supplies, but also by the availability of certain species of animals and plants in the wild. For instance, gathering of certain caterpillars and termites in the rain forests of Central Africa is restricted to one specific period of the year (Bahuchet 1988). Fishing is often only possible during the rainy season when there is enough water in rivers and lakes (Pagezy 1988). It should be noted, however, that for communities for whom hunting/gathering forms a more or less essential part of their food supply, it is difficult to assess whether certain gathering activities should be seen as mechanisms to cope with seasonal stress or as a fixed part of their food supply. Another example is offered by Bernus (1988), who notes that although picking wild grasses is a common activity in all Sahelian pastoral societies, it is considered as general harvesting and not as a famine harvest.

Not all 'famine foods' necessarily grow wild. In the section on agricultural adaptations we have seen that some farmers have plots with cassava, only to be harvested in times of food shortage. In some instances, tree crops are a significant source of alternative food. All local surveys in the Sahel and in northern Nigeria reportedly agree on the importance of this (Apeldoorn 1981).

Rationing of daily meals implies a reduction in the number of meals per day, the quantity of food per meal, and the types of food consumed. This is one of the more drastic ways of coping with hunger but all the same quite common in large parts of Africa and the more severe because, as we have seen, the period of food shortages is also the period of heavy labour.

\section{Community support}

During such times, people also rely heavily on the help of their relatives and on other social relations. In the previous section we noted the existence of such social patterns as patronclient relationships, exchange of gifts and borrowing of animals. During periods of food 
shortages those who suffer most have to call on such support most often. Usually, this places the weaker party - the 'client', the 'receiver', the 'borrower' — in a position of dependence and if conditions do not change for the better during the next season, (s)he may be forced to turn to more drastic measures, such as the sales of assets and farm land.

\section{Immediate cash income}

If cash is immediately needed in order to buy food, two alternatives may be open to the household. First, household members will try to earn money from some kind of casual labour, usually on nearby farms. Second, households may be forced to sell personal possessions, such as jewelry. At the same time, mortgaging of the farm land may take place. Often, this is the forerunner of outright sale, as Longhurst (1986b) observed in northern Nigeria. Among pastoralists, sales of livestock may become inevitable. The richer herders profit from these forced sales, because during the dry season cattle prices are low. As a result, "with each drought year, an increasing number of poor people may be forced out of their pastoral lifestyle" (Swift 1981, 86).

\section{Household migration}

When other means fail a drastic option remains: leaving the homestead to try and find a living elsewhere. In some cases this is a regular occurrence where people have plots of land in other areas, or where moving from camp to camp is part of life (such as among the Pygmies or the Bushmen), or in the case of moving cattle to other, better watered, pastures. However, in other cases it implies moving in with relatives elsewhere or moving to a centre where relief food is distributed. This type of migration is different from regular migration for economic and employment purposes. Another difference is that forced migration concerns whole families, not just one or two single members of the household. Moreover, in the case of relief camps, the chances of returning home are much smaller than in cases of voluntary migration (Apeldoorn 1981; Longhurst 1986b).

\section{External assistance}

In exceptionally grave circumstances, it is also possible that relief from outside is offered, for instance by missionary organisations or governments, although this is usually not offered until two consecutive years of drought have occurred. A recent study in the Pokot area, Kenya, offers an historical overview of the ways in which the government as well as missionary organisations dealt with periods of food shortages. It appears that the effects of these interventions can be very different. On some occasions, the organisations undermined local adaptations and directly contributed to the food crisis. On the other hand, in several cases they played a positive role and offered valuable additions to the indigenous coping mechanisms (Dietz 1987). 


\subsection{Conclusion}

Seasonality is a common phenomenon in Africa. However, its impact is not felt equally in each region and by each household or individual. At least four factors - on different levels of analysis - seem to determine the degree to which adverse effects are felt and, consequently, what coping mechanisms can be used. Firstly the climate, rainfall deciding agroecological conditions; secondly, the form of productive organization; thirdly, the resource level which further determines household conditions and finally, within households, gender and age, resulting in individual differentiation.

- The dryness of the climate is usually expressed in terms of rainfall per year. According to the existing literature, there is a negative correlation between this figure and the several forms of rainfall variability, i.e. the yearly variations in total precipitation, the variations between the same seasons in different years, and spatial variations. In general, the drier the climate the more seasonality will be felt, which in turn implies that agricultural production is more risky and food shortages more likely to occur.

Coping mechanisms will vary with the dryness of climate. In drier regimes, strategies designed to prevent seasonal stress are less likely to have the desired results and people will have to resort to famine-related responses earlier. Mbithi \& Wisner (1973) found some evidence for this in Kenya. They compared adjustments to seasonal droughts in three neighbouring ecological zones. Farmers in the high potential zone were able to tackle seasonality mainly by agronomic measures, i.e. preventive measures. Farmers in the low potential zone, on the other hand, most frequently mentioned famine-related responses like buying food and selling livestock.

- As regards the form of productive organisation, the following observations can be made. In more or less 'traditional' rural societies agricultural production is mainly devoted to household self-subsistence. Specialisation is limited and so is the exchange of produce. Moreover, there is no private ownership of land, and land is not scarce. The strength and viability of such a communitiy depends to a large extent on the number of people and thus on the labour at its disposal. Accordingly there are good reasons to "organise the redistribution of labour and produce in order to maintain as viable production units those households most vulnerable to misfortune, including seasonal stress" (Raikes 1981, 70-71).

In societies with greater economic specialisation of the production process, households sell part of their produce in order to buy goods (and pay taxes). In other words, people are subject to price fluctuations: crop prices tend to be low just after the harvest and high during periods of food shortages. A trading-class in agricultural products is emerging, buying at harvest time and selling in the lean period. As 'modernization' proceeds, the traditional forms of coping with seasonality - based on social networks - will give way to more economically defined adjustments. 
- Poor households experience the effects of seasonality more severely than rich households. Campbell \& Trechter (1982) compared the coping mechanisms of poor and rich households in northern Cameroon. People in relatively poor villages responded to the yearly drought period by slaughtering and selling livestock. People in a better-off village had the possibility to resort to adjustments in the nutritional sphere (eating less did not necessarily mean eating too little) or to earn some money through trade or wage labour. Reardon \& Matlon (1989) demonstrated the same in Burkina Faso (p.12). In cases of more severe food shortages, poor families collected wild foods, while richer farmers, regarding this an onerous and unattractive measure, relied more on borrowing food or money (Longhurst 1986b). In other words, poor people have to resort to famine-related responses at an earlier stage than richer families and they are the ones with the smallest margins to cope with climatic variability.

Some authors stress the increasing socio-economic contrasts at the local level. From a study among the WoDaaBe pastoralists in Niger, White $(1986,23)$ concluded that "seasonality clearly does reinforce poverty". According to Gill $(1991,48)$, the very poor are "trapped in a vicious circle in which undernutrition itself prevents them from securing more food". Poor households are forced to sell part of their crop immediately after the harvest when prices are low, and have later on to buy food when prices are high. Poor pastoralists face the same when they have to sell animals during a period when supply is high and prices low. It is the richer households who are able to profit from this situation, thus accumulating wealth. Besides this market mechanism causing increasing socio-economic differentiation, patron-client relationships play a role. Hiring out as agricultural labourer to wealthier households may have a detrimental effect on the poor household's own food production, thus increasing the dependency on the goodwill of the rich farmer and on the market for food provision. Another way in which rich households become more wealthy at the expense of poor households is through (seasonal) loans, either in food or in cash. In short, due to seasonally recurring food shortages, two interlinked processes take place at the village level, notably one of accumulation for rich households and one of impoverishment for poor households.

- The impact of seasonality on individuals, and the available coping mechanisms, are age and gender-specific. Because of their responsibilities for food production combined with their domestic tasks, women were thought to be more seriously affected by seasonality than men; the more so when they are pregnant or lactating. Because of the separation of tasks, coping mechanisms for women lie more in the spheres of agriculture and nutrition, while men's adjustments to food shortages lie more in the economic sphere (for instance, wage labour). In northern Cameroon, coping with the 'normal' food shortage period was almost entirely a woman's responsibility (Campbell \& Trechter 1982). In cases of more severe drought situations, men and women were equally involved in trying to overcome the stress (Longhurst 1986b). Young children are also quite vulnerable, they often experience considerable consumption deficits at times of food shortages and show serious weight losses at 
such times (Geuns et al. 1991). In case of famine, both morbidity and mortality are first to increase among young children.

Evidently, the above factors are interrelated. For instance, in drier climates there are more poor households, while women in poorer households may be hit harder by seasonal stress than women in richer households. Few comparative seasonality studies have been done. An exception concerns the extensive research project carried out in Burkina Faso in the mid$1980 \mathrm{~s} .10$ Between villages in different climatic zones there appeared to be marked differences not only in the degree that seasonal stress was felt, but also in the ways the local populations were able to cope with it. Although cultural differences were of some importance, environmental factors determined to a large extent the possibilities of diversifying income sources, thus reducing the adverse effects of climatic seasonality. The present study looks at the impact of climatic seasonality, particularly in relation to the agro-ecological conditions of the study areas and in relation to the socio-economic differentiation between households. 


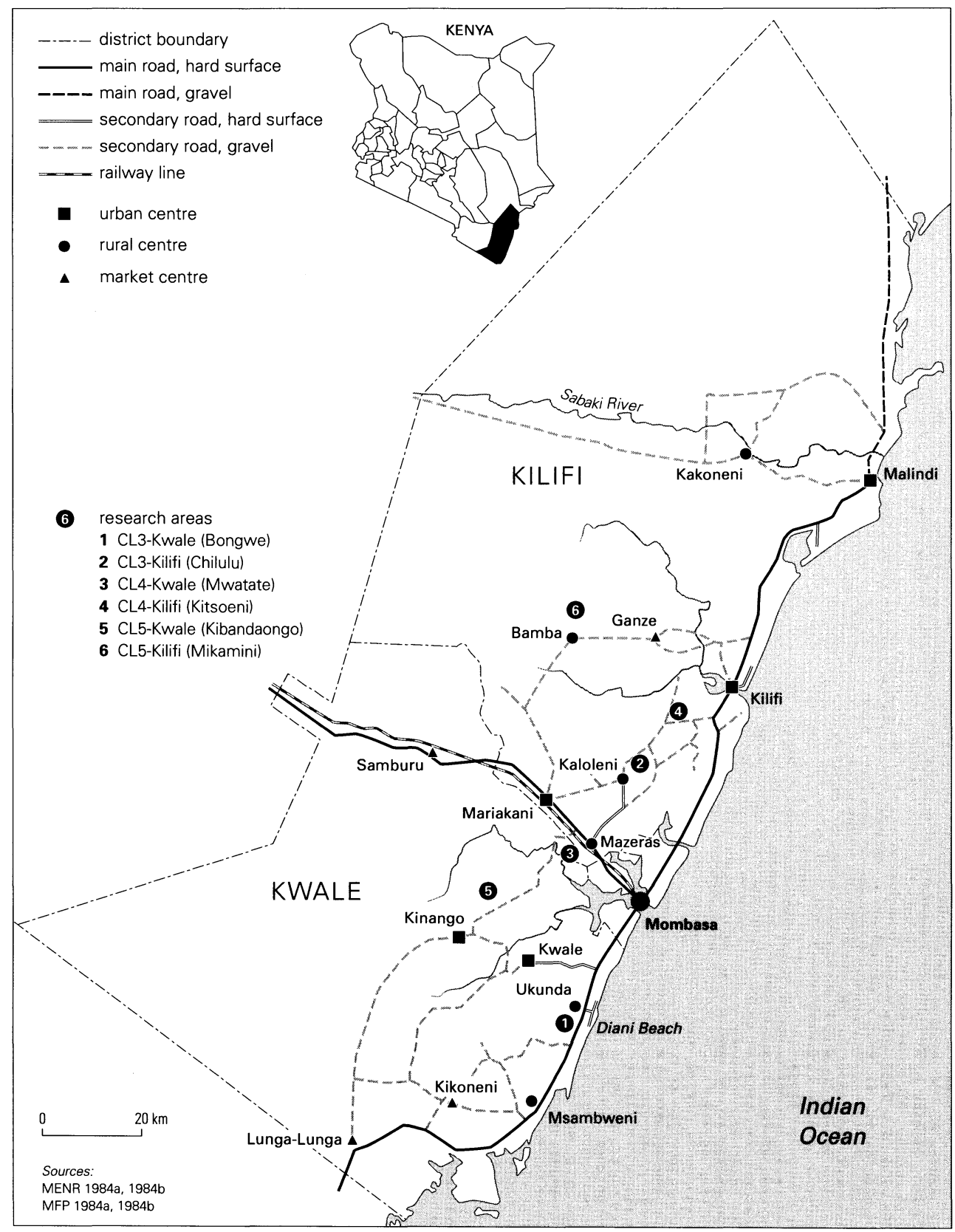

Map 3 Kwale and Kilifi Districts: Roads, service centres and research areas 


\section{Kenya's Coastal Lowlands: Kwale and Kilifi Districts*}

Coast Province is the third area of major population concentration in Kenya, after the Central and Western regions of the country. Kwale, Kilifi, Mombasa and the sparsely populated Lamu District form the coastal region as such with its distinctive ecological and cultural characteristics. The two other districts, Taita-Taveta and Tana River are mostly situated inland and have their own distinct characteristics. Kwale and Kilifi District account for more than two-thirds of the rural population in the province. The climatic and economic conditions of the districts are quite different from those of the highland areas. Going inland, rainfall diminishes quickly while evapotranspiration increases. Most soils are chemically poor and the fertility of the land tends to be low (Boxem, Meester \& Schmaling 1987). Different agro-ecological zones alternate over relatively short distances. Agriculture along the coastline is dominated by food crops and perennial cash crops, while inland livestock rearing is combined with cultivation of food crops. The seasonal character and the low reliability of rainfall, however, severely restrict the scope and productivity of agricultural activities. Maize production in the region is insufficient to feed the population and substantial imports are required from elsewhere in Kenya. The population in the drier zones, in particular, have to deal with the disruptive effects of shorter and longer drought periods.

The economic development of the region has not kept pace with that of other parts of Kenya. Although the coastal lowlands were relatively prosperous in pre-colonial and early

\footnotetext{
${ }^{*}$ This chapter is a revised and updated version of earlier text in Foeken \& Hoorweg (1988, 29-68).
} 
colonial times, the opening of the highlands by European settlers meant an inevitable shift of development towards the interior (Cooper 1981). Afterwards and also in the post-independence period, economic development has stagnated due to a combination of political, economic and social factors. Coast Province, in fact, scores comparatively low on accepted development indicators such as child mortality ( 139 vs. 105 for all Kenya), childhood malnutrition ( $40 \%$ vs. $24 \%$ stunted) and a low literacy rate $(<40 \%$ vs. almost $60 \%$ nationally; GOK/UNICEF 1992). The living conditions of the population in large parts of the province are harsh and estimates place the incidence of rural poverty at forty per cent which is higher than in Kenya as a whole (Meilink i.p.).

\subsection{Infrastructure and Population}

Map 3 (p. 26) shows the network of main and secondary roads, and the location of service centres. There are five all-weather roads, three of which are trunk roads radiating from Mombasa, one north to Malindi, one south to Lunga-Lunga (with a branch to Kwale town), and one westwards to Nairobi (with a branch to Kaloleni). There is a hierarchy of service centres which, administratively, is meant to be as follows: an urban centre serves 120,000 people, a rural centre serves 40,000 and a market centre 15,000 .

There is only one truly urban centre: Mombasa with 460,900 inhabitants in 1989 (CBS 1994). The rural inhabitants constitute about 90 per cent of the population, but they are unevenly distributed over the districts. The majority of the population lives within a relatively short distance from the coast, in the coastal strip which is about $10-15 \mathrm{~km}$ wide, and in the better watered parts just behind it. Further inland, population densities are low. This is caused by differences in agricultural potential, the concentration of modern sector employment in the coastal strip, as well as recent government settlement policies and the history of the various Mijikenda sub-groups.

The majority of the population is of Mijikenda origin (Kwale over 80\%, Kilifi over 90\%), and in that sense the two districts can be regarded as one cultural entity (CBS 1994). Nine ethnic sub-groups are distinguished, Digo and Duruma in Kwale District, the other seven inhabit Kilifi (Giriama, Kauma, Chonyi, Jibana, Kambe, Ribe, Rabai). There are considerable differences in number between these respective sub-groups: Digo, Duruma and Giriama numbered about 100,000 in 1969, the latest date for which figures are available; the Chonyi and Rabai about 30-40,000 and the others less than 10,000 (Spear 1978).

The Mijikenda tribes originated from an area called Singwaya in the southern Somali hinterland, and migrated towards the coastal area at the turn of the 17th century. Initially, they settled in nine, individual, fortified hill-top villages called kayas, along the ridge inland from the southern Kenyan coast. Each kaya probably counted 1,500 to 2,000 inhabitants. As populations grew larger, people left to settle in the nearby lowlands. The Digo were the first to do this, followed by the Giriama and the Duruma. They obtained large tracts of land in the less fertile areas north, south and west of the kaya ridge, the easterly lands along the coastline already being occupied by the original Swahili population. The rapid growth of 
the Digo, Duruma, Rabai and Giriama populations has been explained by the following cultural and economic factors:

\begin{abstract}
(...) the Digo, Duruma and Rabai traced descent matrilineally. By the late 19th century they were all taking large numbers of foreign wives or slave wives as men sought to ensure patrilineal inheritance and descent, thus giving them a higher rate of population increase than the other Mijikenda who were patrilineal. The patrilineal Giriama, on the other hand, were the most successful traders in the 19th century. Their success and their wealth attracted many foreigners, ex-slaves and other dependents, many of whom were adopted into Giriama lineages and served to augment their population. Since many of those adopted by Digo, Duruma, Rabai and Giriama were fellow Mijikenda, abnormal increases of these peoples would have been at the expense of the others and therefore restricted their growth (Spear 1978, 1, 4, 9-10).
\end{abstract}

Table 1 gives successive census data for Kwale and Kilifi Districts as well as for the locations and sub-locations of the six areas that were included in the present study. ${ }^{*}$ Areas with out-migration tend to have low sex ratios because it is usually the men who try and find work elsewhere. The sex ratios for Kwale and Kilifi Districts are below parity. Many men from the two districts work in Mombasa and the Mijikenda migration to the city continues. Between 1979 and 1989 the Mijikenda population in Mombasa increased by 47 per cent (CBS 1981a; 1994).

Besides migration flows across district borders, there also exist internal patterns of population movement. In Kilifi District, people have been moving from the populated southern parts and the arid hinterland to the coastal strip and to the less populated marginal lands north-west of Malindi. Factors behind this migration are the search for arable land and the employment opportunities at the coast (MFP 1984a). In Kwale District, there seems to be a similar shift of population, with people moving out of the areas with the highest risk of crop failure to the relatively better watered parts and to those areas which tend to offer greater employment opportunities. The establishment of settlement schemes in the two districts has also been a contributing factor.

\title{
3.2 Topography, Rainfall and Soils
}

Four major topographical zones can be discerned which run north-south. Going inland they are as follows:

- The Coastal Plain (I), a narrow belt along the coast, with a maximum altitude of about 60 metres. This zone extends to $10 \mathrm{~km}$ inland in the area stretching from Lunga-Lunga on the Tanzanian border to the town of Kilifi. North of Kilifi town, the plain widens until it reaches some $30 \mathrm{~km}$ inland near Malindi town.

- The Foot Plateau (II), the western extension of the Coastal Plain. This plateau has an altitude of 60 to 120 metres, although it is characterised by a relatively flat surface, alternated

\footnotetext{
${ }^{\star *}$ The research areas are referred to by agro-ecological zone and district in which they are situated i.e. CL3Kwale, CL3-Kilifi, CL4-Kwale, CL4-Kilifi, CL5-Kwale, CL5-Kilifi.
} 


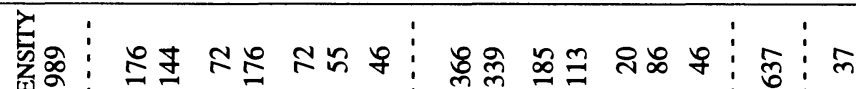
ڤे

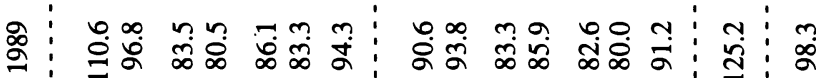

送全 离

跔

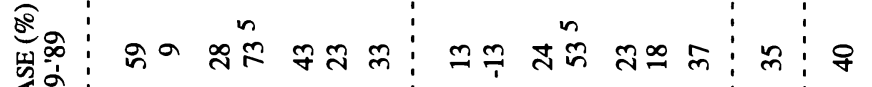
ำ

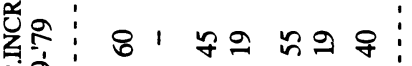
영

2 1 กn

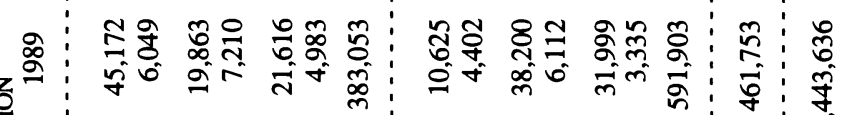
定

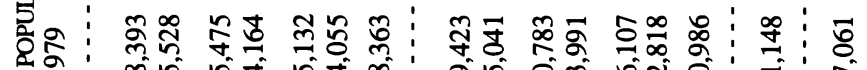

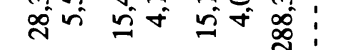

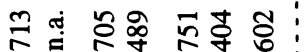

ज्ञां

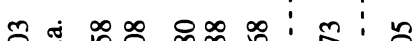

ర్య

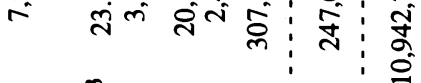

N

.气

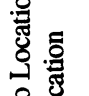

离

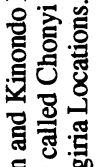

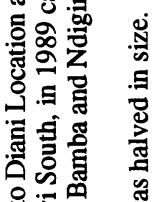

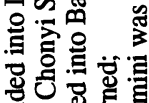

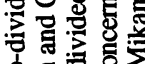

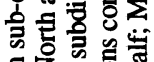

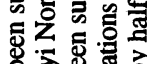
\&

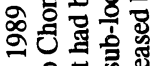
$\Rightarrow$ 을 隹。 空

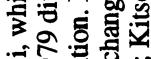
홍

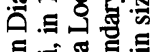

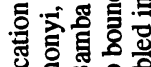

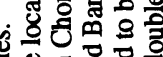
造. o

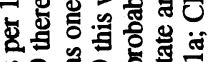
要定

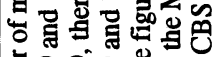

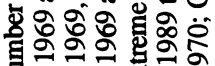

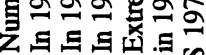
ลสกร์ 
with a number of hills.

- The Coastal Range (III), rising inland rather steeply from the Foot Plateau. This zone includes hill complexes, such as the Shimba Hills in Kwale District and the hilly country of the Mazeras-Kaloleni-Kitsoeni area in Kilifi District, as well as a number of isolated hills.

- The Nyika Plateau (IV), extending to the west of the Coastal Range. It has a gently rolling relief and an altitude of 200 to 300 metres.

Figure 2 shows a cross-section drawn along a WE-line halfway between Mombasa and Kilifi town. The arrows point to the steep slopes which form the transition between the Foot Plateau and the hilly Mazeras-Kaloleni-Kitsoeni area of the Coastal Range. These steep, eastern facing slopes promote rainfall, causing the 'wet islands' in the interior. In general, precipitation in the districts varies with the distance to the coast. Along the coastline, rainfall ranges from $900-1100 \mathrm{~mm}$ per year in the north-east of Kilifi District to more than $1300 \mathrm{~mm}$ per year in the south-east of Kwale District. About 40 to $50 \mathrm{~km}$ inland, the $700 \mathrm{~mm}$ isohyet is found. However, this general picture is slightly disturbed by the relief of the two districts and annual precipitation does not show a perfect east-west continuum. Evapotranspiration, on the other hand, shows a much more regular pattern, with only the Shimba Hills forming a disturbance in the east-west gradient. Comparing mean annual rainfall with mean annual evapotranspiration, there is a considerable water deficit. But, while evaporation is equally distributed throughout the year, rainfall is not. There is "a pronounced concentration of rainfall at the beginning of the April-June rains, particularly in the hinterland" (Smaling \& Boxem 1987, 14). This means that there is a water surplus only during relatively short periods of time. These periods determine the length of the growing periods, which are generally short in Coast Province.

The soil types broadly correspond with the topographical division. In the Coastal Plain, soils have developed on coastal sands and coral limestones and are generally well-drained but vary in depth and structure. Their fertility is moderate to low. The soils of the Foot Plateau are deep and well-drained, but also with moderate to low fertility. Soil units in the

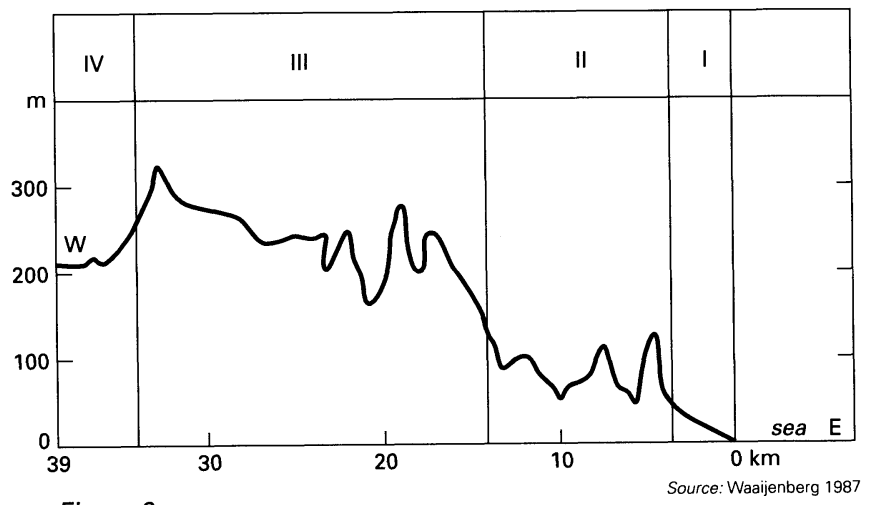

Figure 2

Topographical cross-section of Kilifi District, halfway between $\mathrm{CL} 3$ and $\mathrm{CL} 4$ research area 


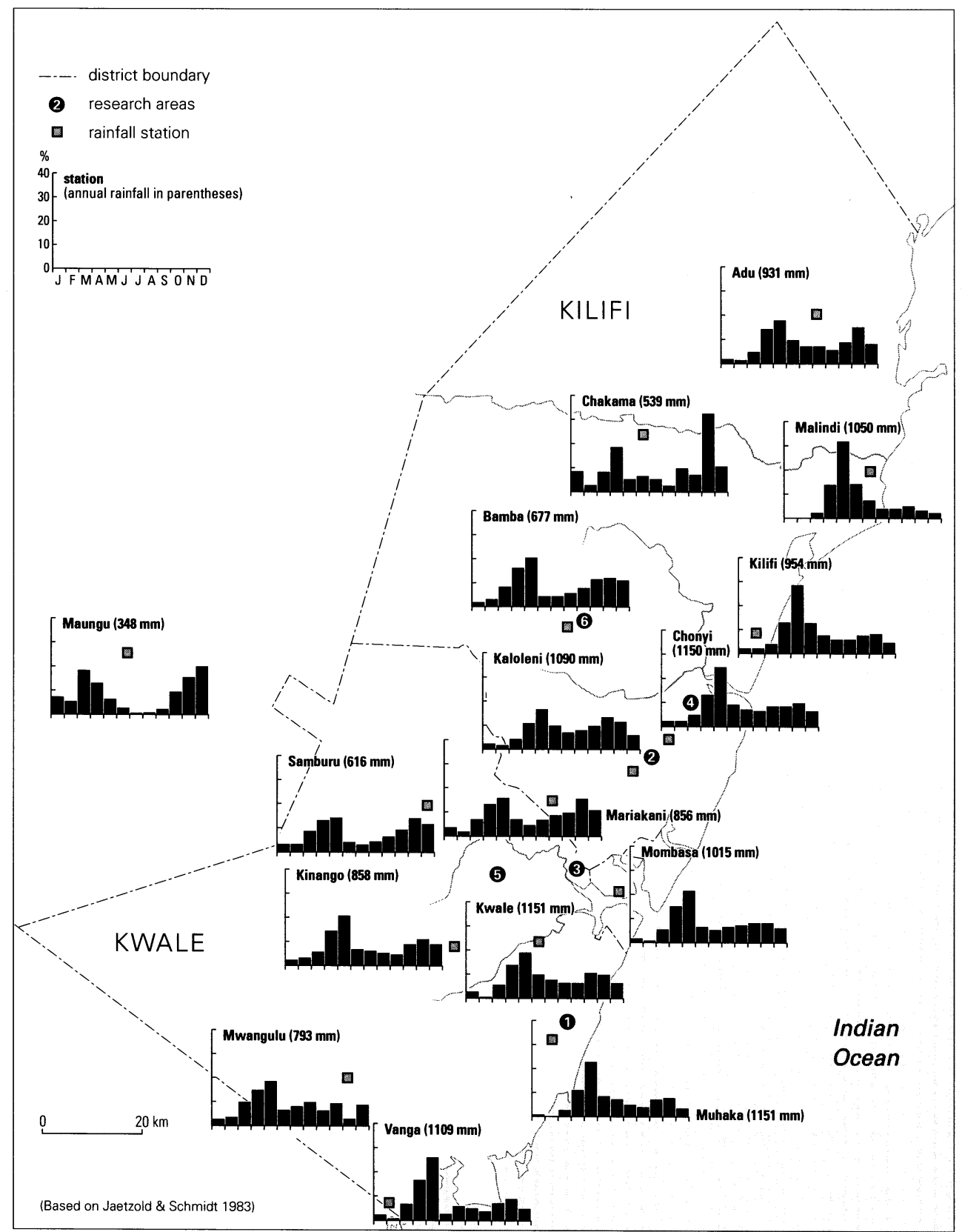

Figure 3

Mean monthly rainfall as percentage of mean annual rainfall for selected stations in Kwale and Kilifi Districts 
Coastal Range vary greatly. Depending on the ways in which they were formed and the type of parent material, they range from well-drained, deep, sandy and clayey soils with varying degrees of fertility to shallow, coarse, sandy soils which, especially on the steeper slopes of the hills and hill complexes, are prone to erosion. Finally, the soils of the Nyika Plateau are sandy and clayey in nature and, in general, their fertility is low although in certain places fertile soils occur. Many soil units in this zone are degraded because of erosion. Areas with really fertile soils in the two districts are scarce (Jaetzold \& Schmidt 1983). The major parts have a moderate to low soil fertility. Particularly, the northern half of Kilifi District is infertile.

\subsection{Climatic Seasonality}

Two methods of measuring climatic seasonality were discussed earlier (p. 7). Absolute seasonality was determined as the average number of 'dry' months per year. Relative seasonality was measured by means of the seasonality index (si). Walsh (1981) divided both absolute seasonality and relative seasonality into seven classes: the former ranging from A (no dry month) to $\mathrm{G}(12$ dry months), the latter from 0 (si<0.20) to $6(\mathrm{si}>1.20)$. The southern part of Kenya (including Coast Province) was classified as type E3, i.e. with 8-9 dry months (E) and si ranging from 0.60 to 0.79 ( 3 or 'seasonal').

However, if one studies the rainfall data of Coast Province in more detail, the climatic situation appears to be much more diverse. Table 2 presents data for selected stations in Kwale and Kilifi Districts which are evenly spread over the districts and located near the six areas included in the present study (see p. 39). For each station, the absolute seasonality and the seasonality index have been calculated. No fewer than seven different seasonality types are present in Table 2, ranging from D2 to G3. The ' 2 ' types, with a seasonality index of 0.40-0.59 that are considered 'rather seasonal', predominate. The existence of so many different climatic types in the two districts is mainly caused by the number of dry months, ranging from seven in Kaloleni and Kwale town to the maximum of twelve in Samburu. Thus, on the one hand, Coast Province appears more seasonal because of the presence of $F$ and $G$ types (absolute seasonality). On the other hand, the region also appears less seasonal because of the presence of mainly ' 2 ' types (in respect of relative seasonality). Figure 3 shows rainfall distribution throughout the year for the stations in Table 2 and which turns out to be extremely varied. Along the narrow coastal plain, a unimodal climate prevails, i.e. with one rainfall peak around May, Malindi being the clearest example. More inland, a weak bimodal regime is found - with two wet seasons, one in AprilMay and one in October-December. This is the intermediate region between the unimodal type at the coast and the real bimodal type further inland (Braun 1985). In Kwale and Kilifi, the period between the first rains and the second rains is not totally dry, which is the reason for the moderate seasonality indices. The only real dry months are January and February. 


\begin{tabular}{|c|c|c|c|c|c|c|c|}
\hline District & $\begin{array}{l}\text { Altitude } \\
(m)\end{array}$ & Station & $\begin{array}{l}\text { Number of } \\
\text { recorded } \\
\text { years }\end{array}$ & $\begin{array}{c}\text { Mean annual } \\
\text { rainfall } \\
(\mathrm{mm})\end{array}$ & $\begin{array}{l}\text { Number } \\
\text { of dry } \\
\text { months }\end{array}$ & $\begin{array}{l}\text { Seasonality } \\
\text { index } \\
\text { (si) }\end{array}$ & Type* \\
\hline Kilifi & $\begin{array}{r}120 \\
91 \\
3 \\
8 \\
244 \\
256 \\
226 \\
204\end{array}$ & $\begin{array}{l}\text { Adu } \\
\text { Chakama } \\
\text { Malindi, D.O. } \\
\text { Kilifi, D.O. } \\
\text { Bamba } \\
\text { Chonyi } \\
\text { Kaloleni } \\
\text { Mariakani }\end{array}$ & $\begin{array}{l}11 \\
16 \\
78 \\
53 \\
18 \\
33 \\
33 \\
15 \\
34\end{array}$ & $\begin{array}{r}931 \\
539 \\
1050 \\
954 \\
677 \\
1150 \\
1090 \\
856\end{array}$ & $\begin{array}{r}9 \\
11 \\
10 \\
9 \\
10 \\
9 \\
7 \\
9\end{array}$ & $\begin{array}{l}0.45 \\
0.58 \\
0.76 \\
0.56 \\
0.54 \\
0.43 \\
0.40 \\
0.41\end{array}$ & $\begin{array}{l}\text { E2 } \\
\text { F2 } \\
\text { F3 } \\
\text { E2 } \\
\text { F2 } \\
\text { E2 } \\
\text { D2 } \\
\text { E2 }\end{array}$ \\
\hline Mombasa & 56 & Port Reitz & 30 & 1050 & 10 & 0.45 & F2 \\
\hline Kwale & $\begin{array}{r}279 \\
305 \\
393 \\
60 \\
122 \\
12\end{array}$ & $\begin{array}{l}\text { Samburu } \\
\text { Kinango } \\
\text { Kwale Town } \\
\text { Muhaka } \\
\text { Mwangulu } \\
\text { Vanga }\end{array}$ & $\begin{array}{l}42 \\
47 \\
64 \\
34 \\
21 \\
40\end{array}$ & $\begin{array}{r}616 \\
858 \\
1151 \\
1151 \\
739 \\
1109\end{array}$ & $\begin{array}{r}12 \\
10 \\
7 \\
9 \\
10 \\
10\end{array}$ & $\begin{array}{l}0.46 \\
0.42 \\
0.43 \\
0.51 \\
0.41 \\
0.55\end{array}$ & $\begin{array}{l}\text { G2 } \\
\text { F2 } \\
\text { D2 } \\
\text { E2 } \\
\text { F2 } \\
\text { F2 }\end{array}$ \\
\hline Taita & 517 & Maungu & 12 & 384 & 12 & 0.66 & G3 \\
\hline Kitui & 1158 & Kitui & 29 & 1015 & 8 & 0.95 & $\mathrm{E} 4$ \\
\hline
\end{tabular}

* $\mathrm{D}=5-7$ dry months; $\mathrm{E}=8-9$ dry months; $\mathrm{F}=10-11$ dry months; $\mathrm{G}=12$ dry months

2: $s i=0.40-0.59 ; 3: s i=0.60-0.79 ; 4: s i=0.80-0.99$ (see Walsh 1981)

Sources: Meteorological Dept., Nairobi (Kinango, Muhaka); Jaetzold \& Schmidt 1983 (other stations)

Another important rainfall feature, especially in the drier climates, is the interannual variability, measured as the yearly deviation from the average annual rainfall. Table 3 shows - for six rainfall stations close to the respective research areas - the number of years in which the total annual rainfall deviates at least 20 per cent from the average annual rainfall. In three stations this occurs in six out of every ten years, in two stations once in every two years. In five of the six stations, a deviation of no less than 40 per cent occurs once in every four or five years. There appears to be no relation between the degree of deviation on the one hand and the average annual rainfall on the other. Thus, the earlier hypothesis that the drier the climate the greater the annual variability is not confirmed in this case. When rainfall shows large yearly fluctuations, monthly rainfall also varies substantially.

Monthly rainfall can also vary between years with the same overall rainfall, as the four examples in Figure 4 (p. 38) illustrate. For each of the four stations, two years have been selected with a total rainfall nearly equal to the average annual rainfall. Nevertheless, the monthly distributions are highly different. In the one year there is a clear rainfall peak during the first rains, in the other year during the second rains. This variation reflects that even in years with 'normal' or 'above-normal' rainfall, the monthly distribution does not necessarily coincide with the needs of the agrarian cycle. 


\begin{tabular}{|c|c|c|c|c|c|c|}
\hline \multirow[t]{2}{*}{ Station } & \multirow{2}{*}{$\begin{array}{c}\text { Number of } \\
\text { recorded } \\
\text { years }\end{array}$} & \multirow{2}{*}{$\begin{array}{c}\text { Mean annual } \\
\text { rainfall } \\
(\mathrm{mm})\end{array}$} & \multicolumn{4}{|c|}{$\begin{array}{l}\text { Years with rainfall deviating from } \\
\text { annual mean by given percentage }\end{array}$} \\
\hline & & & $0-20 \%$ & $21-30$ & $31-40$ & $>40 \%$ \\
\hline Kinango & 42 & 835 & 38 & 24 & 17 & 21 \\
\hline Muhaka & 33 & 1151 & 39 & 25 & 24 & 12 \\
\hline Kaloleni & 19 & 1069 & 42 & 21 & 11 & 26 \\
\hline Mariakani & 10 & 822 & 50 & 10 & 0 & 40 \\
\hline Chonyi & 13 & 1163 & 62 & 7 & 8 & 23 \\
\hline Bamba & 11 & 657 & 45 & 10 & 18 & 27 \\
\hline
\end{tabular}

Source: Calculated from data from the Meteorological Department, Nairobi.

This last type of rainfall fluctuation shows considerable spatial variation. Kinango and Muhaka are two stations which are only 30 kilometres apart as the crow flies. Although the yearly rainfall shows a high degree of correlation between the two stations, there are also some marked differences. In 8 out of the 32 years for which figures are at hand, the difference between their respective deviations from mean annual rainfall was 25 per cent or more. In Kinango and Bamba, the two 'dry' stations in our example, this happened in four out of eleven recorded years in the 1972-1985 period.

In review, it is striking how rainfall fluctuates, not only intra-annually and inter-annually but also between the same months in different years, as well as between places. In other words, it is highly unpredictable when the rains will start, how much rain will fall, and how the rain will be distributed over the seasons. Since rainfall determines the agricultural calendar, this makes the crop cycle equally uncertain.

\subsection{Agro-Ecological Zones}

Agricultural potential and growing periods of crops are largely decided by the following determinants: a) temperature, b) annual rainfall, and c) seasonal distribution of rainfall. Based on these three elements, Jaetzold \& Schmidt (1983) have arrived at the following agro-ecological zonation for the different districts of Kenya.

Firstly, zone groups are based on temperature belts, defined according to the maximum temperature limits within which the main crops in Kenya can flourish. Kwale and Kilifi belong to one temperature belt, with mean annual temperature higher than $24^{\circ} \mathrm{C}$ and mean maximum temperature lower than $31^{\circ} \mathrm{C}$. This zone group is denoted as $\mathrm{CL}$, i.e. Coastal Lowlands. Secondly, within these zone groups, main zones are distinguished, determined by the mean annual rainfall. These main zones are based on their probability of meeting the temperature and water requirements of the main leading crops. In Kwale and Kilifi Districts, there are five main agro-ecological zones, ranging from CL2 (where '2' stands for 'sub-humid') to CL6 ('arid'), characterised by the leading crops and agricultural activities (Map 4): 


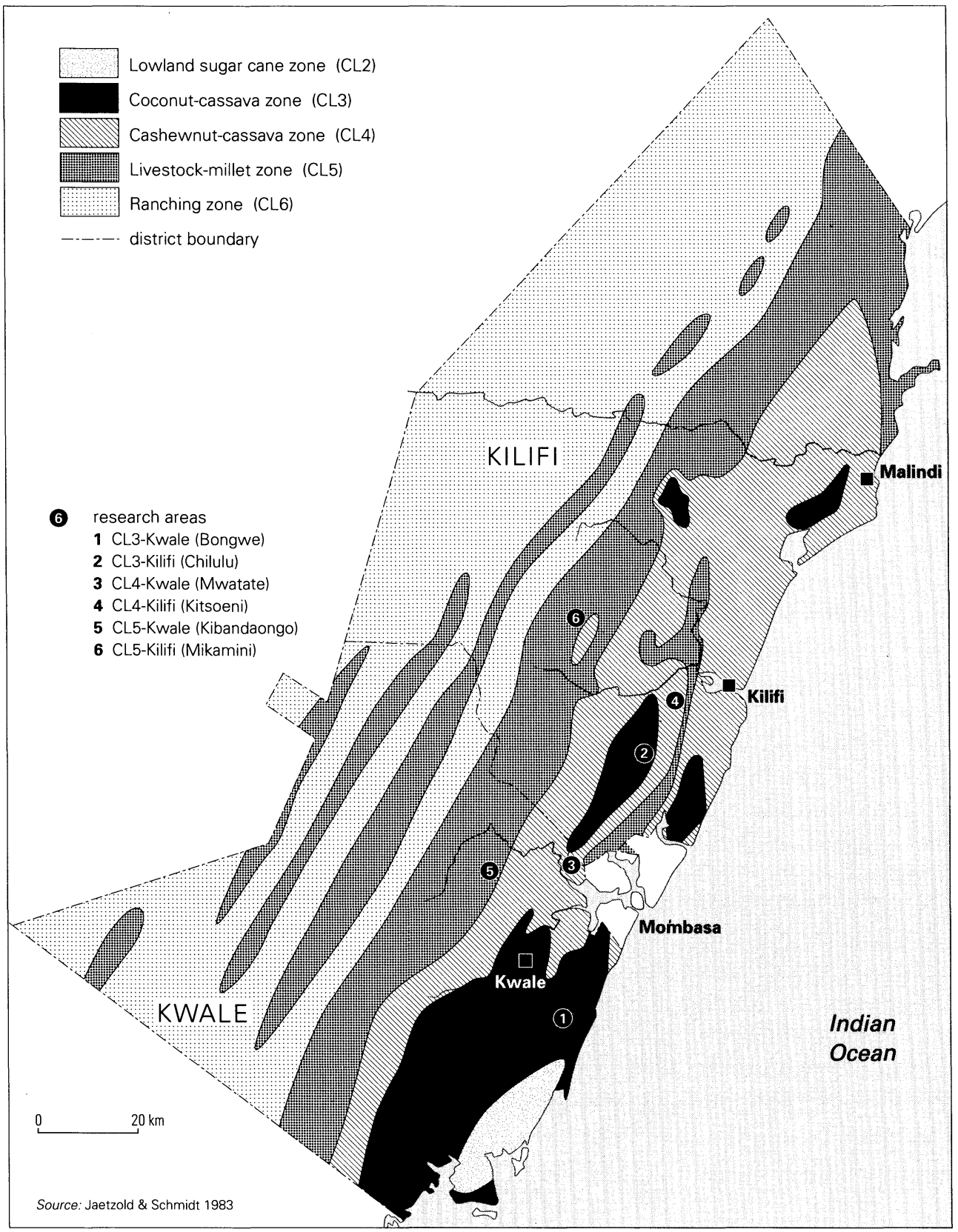

Map 4 Kwale and Kilifi Districts: Agro-ecological zones 
- The sugar cane zone (CL2) is only found in a small part of Kwale District and has an annual rainfall of over $1400 \mathrm{~mm}$. It was mainly used for sugar cane production until the collapse of the Ramisi sugar factory in 1989.

- The coconut-cassava zone (CL3), about $1,450 \mathrm{~km}^{2}$ in size, has a medium potential for agricultural activities. The annual precipitation averages about $1200 \mathrm{~mm}$, but the short rains do not allow for cultivation of a wide range of annual crops.

- The cashewnut-cassava zone (CL4) totals about $2,940 \mathrm{~km}^{2}$ and has a low to medium potential for cropping. Rainfall averages $1000 \mathrm{~mm}$ annually, but in only six out of ten years the amount and distribution of the long rains are likely to be adequate for the production of annual crops. Cultivation of annual crops during the period of the short rains is normally not possible.

- The livestock-millet zone (CL5), with $5,000 \mathrm{~km}^{2}$ the largest land area, is characterised by an average annual rainfall of about $800 \mathrm{~mm}$ and very unreliable rains. Due to the short duration of the long rains, crop production in this zone is restricted to drought-resistent crops. - The ranching zone (CL6), finally, has virtually no potential for arable agriculture. Annual precipitation is less than $700 \mathrm{~mm}$ on average and is extremely unreliable. Agricultural activities are restricted to extensive types of livestock rearing.

Table 4 shows the distribution of the main zones in the two districts which have similarities with the earlier topographical characteristics, although there are considerable differences because of local rainfall and soil conditions. Two-thirds of the agricultural lands belong to the low potential category (CL5 and CL6), while only 12 per cent is considered to be medium or high potential land. It is not surprising that three-quarters of the farm households are found in one-third of the area. Nearly all of the rural population lives in the three zones CL3, CL4 and CL5 and population density generally decreases in that order.

Since considerable variations in rainfall distribution over the seasons exist, as described earlier, the main agro-ecological zones can be divided into sub-zones. Using as criteria the length of the first and second rainy seasons and the existence of intermediate rains, a range of combinations is possible. Together with mean annual rainfall they determine the types of crops which can be grown and, to a lesser extent, yield potential. The latter is also

\begin{tabular}{|c|c|c|c|c|c|c|}
\hline $\begin{array}{l}\text { A.E. } \\
\text { zone* }\end{array}$ & $\begin{array}{c}\text { Kwale } \\
\mathrm{km}^{2} \%\end{array}$ & $\begin{array}{c}\text { Kilifi } \\
\mathrm{km}^{2}\end{array}$ & $\begin{array}{c}\text { Totc } \\
\mathrm{km}^{2}\end{array}$ & al $\%$ & $\begin{array}{l}\text { Farm fa } \\
(N)\end{array}$ & $\begin{array}{c}\text { nilies } \\
\%\end{array}$ \\
\hline CL2 & 235 & - & 235 & 2 & 3,000 & 3 \\
\hline CL3 & $953 \quad 13$ & 496 & 1,449 & 10 & 34,000 & 28 \\
\hline CL4 & $897 \quad 12$ & $2,045 \quad 29$ & 2,942 & 20 & 54,000 & 45 \\
\hline CL5 & $2,342 \quad 32$ & $2,658 \quad 37$ & 5,000 & 35 & 17,000 & 14 \\
\hline CL6 & $2,886 \quad 40$ & $1,914 \quad 27$ & 4,800 & 33 & 12,000 & 10 \\
\hline total & $=7,313 \quad 100$ & $=7,113 \quad 100$ & $=14,426$ & 100 & $=120,000$ & 100 \\
\hline
\end{tabular}

* CL2=Sugar cane; CL3=Coconut-cassava; CL4=Cashewnut-cassava; CL5=Livestock-millet; CL6=Ranching zone. Source: Jaetzold \& Schmidt 1983, 309, 350. 

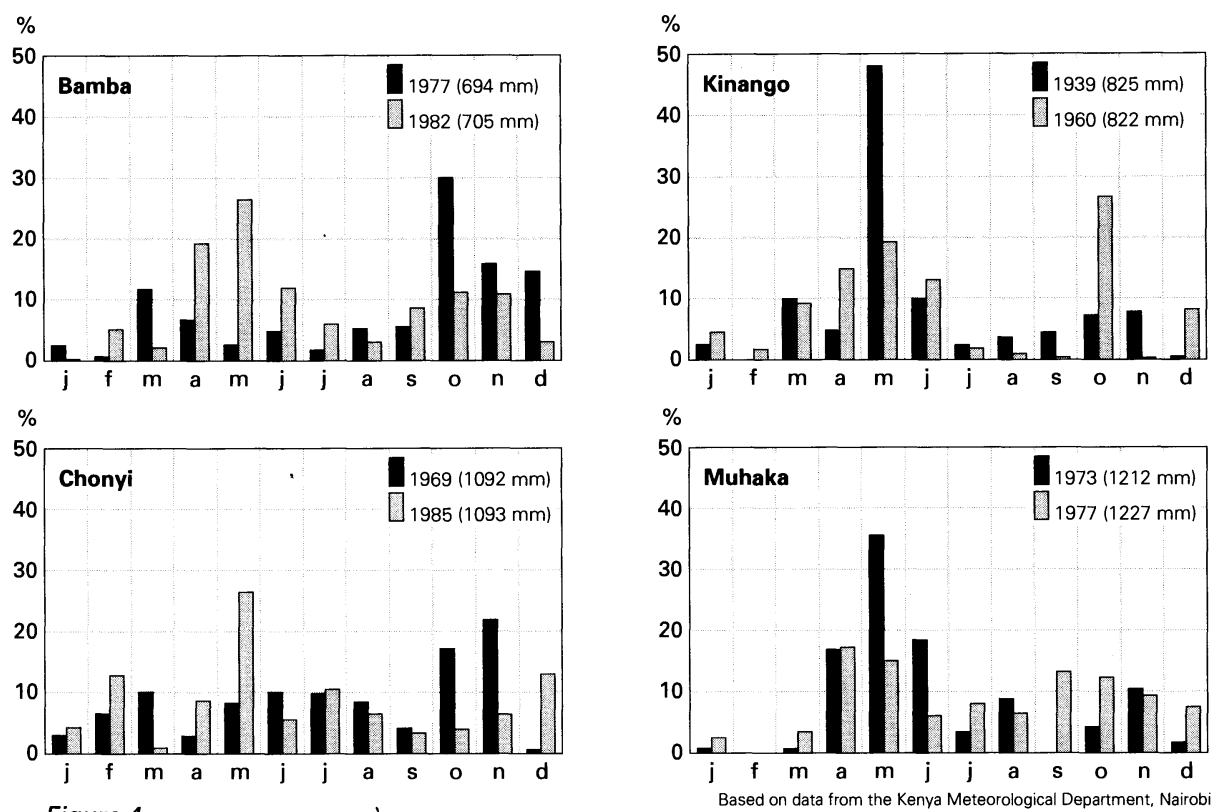

Figure 4

Monthly rainfall as percentage of year total for selected years at four rainfall stations

influenced by soil characteristics such as depth, texture and chemical and physical structure.

The six survey areas selected for this study are situated in Kwale and Kilifi District in the three agro-ecological zones CL3, CL4 and CL5. Zones CL2 and CL6 were not included. One research area was situated in each zone in each district, six research locations altogether. They are listed in Table 5 with the names of the administrative units in which they are situated and the sub-zone characteristics.

\subsection{Agriculture}

Appendix 1 gives a review of potential crop yields by research area and season. There are sharp contrasts in the various crops that can be grown. In the CL3 sub-zones many permanent crops (fruits, cassava, etc.) offer good yields, in the CL5 sub-zones only a few of such crops will grow. Secondly, the growing period during the first rains in the CL3 subzones is so much longer than in the CL5 sub-zones that practically all annual crops give satisfactory yields in good years. In the CL5 sub-zones, this is only the case with some drought-resistant grains (sorghum, millet) and vegetables (green grams, gourds). Other crops give at best 'fair' yields. The CL4 sub-zones have only a slightly shorter growing period than the CL3 sub-zones, but the difference regarding crops and crop yield potentials 


\begin{tabular}{|c|c|c|c|c|c|c|c|}
\hline $\begin{array}{l}\text { A.E.zone } \\
\text { \& district }\end{array}$ & Location & $\begin{array}{c}\text { Sub- } \\
\text { location }\end{array}$ & Sub-zone* & $\begin{array}{c}\text { Mean } \\
\text { annual rain- } \\
\text { fall }(\mathrm{mm})\end{array}$ & $\begin{array}{l}\text { Length 1st } \\
\text { growing } \\
\text { period (days) }\end{array}$ & $\begin{array}{l}\text { Inter- } \\
\text { mediate } \\
\text { rains }\end{array}$ & $\begin{array}{l}\text { Length } 2 \text { nd. } \\
\text { growing } \\
\text { period (days) }\end{array}$ \\
\hline CL3-Kwale & Diani & Bong & $\mathrm{m} / \mathrm{l}, \mathbf{i}$ & $1100-1200$ & $155-174$ & yes & - \\
\hline CL3-Kilifi & Jibana & Chilulu/Ts. & $\mathrm{m} / \mathbf{l}, \mathbf{i}, \mathbf{s}$ & & 74 & yes & $85-104$ \\
\hline CL4-Kwale & Mwavumbo & Mwatate & $\mathrm{m}, \mathbf{i}, \mathbf{v s}$ & $1000-1100$ & $135-154$ & yes & $40-54$ \\
\hline CL4-Kilifi & Chonyi (N) & Kitsoeni & $\mathrm{m} / \mathbf{s}, \mathbf{i}, \mathbf{v s}$ & $1000-1100$ & $115-134$ & yes & $40-54$ \\
\hline CL5-Kwale & Kinango & Kibandaongo & $\mathbf{s , i , v s}$ & & $85-104$ & yes & $40-54$ \\
\hline CL5-Kilifi & Bamba & Mikamini & vs/s,vs & $700-800$ & $55-74$ & no & $40-54$ \\
\hline
\end{tabular}

* growth period: $\mathrm{m} / \mathrm{l}=$ medium to long; $\mathrm{m}=$ medium; $\mathrm{m} / \mathrm{s}=$ medium to short; $\mathrm{s}=\mathrm{short} ; \mathrm{vs} / \mathrm{s}=$ very short to short; vs=very short; $\mathrm{i}=$ intermediate rains. Source: Jaetzold \& Schmidt 1983.

is nevertheless remarkable. Thirdly, as mentioned earlier, in most areas the growing period during the second rains is too short. In the CL3-Kwale area there is no second cropping period. However, the long intermediate rains explain why many year-round crops mature well in that area. In the other areas, a second growing period exists (at least, in 'normal' years), but rainfall is only slightly above what has been labelled as intermediate rains. Only a few drought-resistent crops can be grown then, but at best with 'fair' results.

A number of surveys have been carried out on the smallholder agricultural sector in the two districts in previous years 11 Farm surveys in 1977 in the coconut-cassava (CL3) and the cashewnut-cassava (CL4) zones reported an average holding size of 8.2 ha for the smallholders in Kwale District and 6.5 ha for those in Kilifi District (Jaetzold \& Schmidt 1983), which is quite high. Carlsen (1980) estimated an average holding size of 8.8 ha from his survey of 98 farm households in the coconut-cassava zone (CL3) near Kikoneni in Kwale District. There are considerable variations in holding size, not only between the different agro-ecological zones, but also among the different households living within similar zones. As a general rule, smaller holdings dominate in the more humid, populated areas whereas larger farms are found in the marginal farm lands in the western part of the districts, reflecting differences in the carrying capacity of the land.

Agriculture is still traditional in many respects and little developed: (1) land registration has only been completed in some parts, (2) the degree of agricultural modernization is low, and (3) the cultivation of food crops for home consumption predominates (Waaijenberg 1993). The registration of land is still in progress. In the hinterland, the land is administered in group ranches, with established grazing rights for the communities living there. In the more densely populated areas of the narrow coastal strip and the hills of the Coastal Range, most of the land has been adjudicated. But registration is a complex matter, and modern laws on land rights often do not fit in with the traditional land use and usufruct in Coast Province. Farmers are in the habit of mortgaging and renting out not only land, but also the trees on the land, and the fruits on the trees, so that often different owners have quite legitimate claims. 
In their choice of crops farmers traditionally take into account the topography of the land and soil fertility. Recently, because of growing population and increasing pressure on land, there is a tendency towards over-exploitation: repeated cultivation of the same crop(s), prolonged exploitation and short fallow periods. Farming practices are generally labour-intensive. The large majority of farmers use the machete (panga) and hoe (jembe) for land clearance and preparation. Planting is done by hand. The seeds are planted over the field in an irregular manner. Plant densities are low. Mixed cropping is common and involves almost every possible combination of crops. Parts of the maize fields are often interplanted with cassava or pulses. Weeding is labour-intensive and done by hand, once or twice a season. Inputs for which money is required - tractors, fertilizers, insecticides, etc. - are little used. Yields per acre are low, and due to the unreliable rainfall vary from year to year (Schreurs 1982; Waaijenberg 1994).

The cropping pattern is dominated by food crops. Maize and cassava are by far the most important crops, followed by pulses and, in some wet parts, rice. Sorghum and millet, both indigenous and drought-resistant cereals, are hardly grown anymore as people prefer maize. Compared to sorghum and millet, maize has a higher production potential and is less vulnerable to diseases and pests, especially bird attacks. It is also more easily harvested, transported stored and prepared for consumption. On the other hand, it is more vulnerable to drought and flooding and requires well-drained and fertile soils. Cassava is a much less demanding crop in terms of water needs, soil fertility and labour. It can remain in the field throughout the season, so that for most farmers it can serve as a reserve crop to be used in times of food shortages. However, the cassava in Coast Province is infected with the mosaic virus, causing considerable yield reductions. Pulses like beans, cowpeas, pigeon peas, green grams and groundnuts are commonly grown but only in small quantities. Vegetables are grown incidentally, and also in small quantities.

The most important cash crops are coconut palms and cashewnut trees and other minor crops, for example citrus trees, sim-sim and bixa. The income from most crops, however, is low and often unreliable. Waaijenberg has discussed some of the reasons for this. The production of citrus trees and bananas is very sensitive to the weather, often limited to a short period of the year, and varies strongly from year to year. In productive years prices tend to be low. Cashewnut yields are low, confined to a short period of the year, and very variable. Poor yields in past years and low prices caused many farmers to cut their trees to make place for maize. The coconut palm is an exception and "acts as a buffer in the otherwise insecure economy of the Mijikenda, (.....) because it yields a variety of products which are in continuous demand for home consumption and sale (....)". Still, among farmers surveyed, the annual income per palm (fresh nuts, copra and makuti) was no more than sh.30. An exception forms the tapping of toddy and selling of palm wine, but this trade is illegal (Waaijenberg 1994, 236).

Livestock of the East African Zebu type is mainly found in the hinterland under the traditional rangeland husbandry. Small numbers of improved breeds are found in the coastal strip on medium and large farms 12 In the CL3 and CL 4 zones, there are few cattle; the occasional herd usually numbers less than 25 head, while further inland herd size in- 
creases with an average of 60 head or more (Bartman 1984). Goats and sheep are common and nearly all households have some poultry. Goats and sheep are usually tethered or herded with animals from other owners, especially in the drier, less densely populated areas. Poultry range freely around the compound. The animals are generally kept for their meat and also serve as a financial reserve to be sold when necessary. The animals are also slaughtered on ceremonial and religious occasions.

The main characteristics of traditional cattle farming are communal grazing, looking after cattle of others, pooling and dividing cattle over several herds. Bartman (1984) estimated that in Kilifi over three-quarters of the herds are composed of cattle from different owners ( 2 to 9 owners per head), while nearly one-third of the herd keepers have lent out cattle to others. The ethnic groups living in the hinterland of Coast Province - the Giriama in Kilifi District and the Duruma in Kwale District - are the main cattle holders. Cattle is traditionally kept for different purposes but the impression is that the role of cattle in these societies is diminishing. The dowry is still expressed in number of cattle although it is more and more often paid in cash. Historically, cattle also formed an important reserve for periods of food shortage.

Existing information indicates that milk production and consumption levels in Coast Province are low (CBS 1981b; 1983). However, in the dry areas milk was always an important product. It is collected by the households looking after the animals and usually forms the payment for their services. Calving and milk production are seasonally related. Most of the calves are born in the long rainy season at the time when also the natural conditions for milk production are favourable. During the dry season water can be found only at long distances and the quality and quantity of roughage is restricted, both factors limiting the milk production of cows in lactation. These seasonality effects are more pronounced in the local herd than in the improved breeds, because the first are more exposed to changes in natural conditions. In the hinterland, there is usually a surplus of milk production over local consumption during the long rains, because of the high milk production during this period and because of the low purchasing power of the population in that area. As a result, farmers revert to the making of ghee from the milk for sale at markets in coastal towns. The large dairy farms situated in the coastal strip process the milk before selling at distribution centres or delivering to individual shopkeepers. The few smallholder dairy farmers usually deliver directly to consumers or sell at the farm gate (Leegwater, Ngolo \& Hoorweg 1991).

Besides crop cultivation and livestock keeping, there are other ways of exploiting natural resources, either farm-related or not. Examples are homecrafts, honey production, and charcoal-burning. Traditionally, the Kwale population was involved in pot-making, iron-smelting, salt-collecting and making of handicrafts. Honey-production is growing in importance in Kwale, witness the growth in so-called Kenya Top Bar Hives (MFP 1984b). Charcoal-burning is a lucrative activity because of the high demand in towns like Mombasa, Kwale, and Kinango for cooking purposes. In Kwale District, the charcoal is mainly derived from communal lands or group ranches. 


\subsection{Farming Systems}

The farming systems of Kwale and Kilifi are rather complex and differ from those found elsewhere in Kenya. The available information points to the existence of four basic systems. In three of them, smallholder farmers combine annual food crop cultivation with perennial cash crop cultivation but with little or no livestock production. The fourth system is mainly geared to livestock production, with additional food crop cultivation for subsistence. The location of each of these farming systems is closely related to the differences in ecology described above.

The size of the farm area cultivated depends on the agro-ecological environment and the specific farming system, but also on the availability of family labour, because of the low levels of technology utilized. The area under annual and perennial crops is generally rather small. For instance, the average farmer in the coconut-cassava zone (CL3) in Kwale District used about 50 per cent of the holding for the cultivation of annual and permanent crops. The remainder was either used as pasture land or left fallow. Farmers near Kikoneni cultivated some 85 per cent of their holding, the rest of the land being left fallow (Carlsen 1980). Smallholders living in the same agro-ecological zone in Kilifi District devoted almost two-thirds of their land to crop cultivation (Jaetzold \& Schmidt 1983).

On smallholder farms in the coconut-cassava (CL3) and the cashewnut-cassava (CL4) zones it is possible to grow commercial tree crops like coconuts, cashewnuts, mango and citrus, while annual food crops such as maize, cassava, paddy, pulses and vegetables, are found in varying combinations. Surveys indicate that farmers in these zones have about equal proportions of their crop land under food crops and under commercial crops (Jaetzold \& Schmidt 1983). However, the relative importance of the different crops in the cropping pattern depends on the specific micro conditions of the individual farms. In parts of Kilifi District, sesame and cotton are sometimes included in the cropping system, whereas bixa is a cash crop in part of Kwale.

In the drier parts of the CL4 zone and in the livestock-millet zone (CL5), cash crop cultivation is unimportant and farmers mainly depend on the production of annual food crops such as maize, cassava, millet, sorghum and pulses. As already mentioned, only the drought-resistant crops like sorghum, millet and pulses offer good yield potentials but, since the turn of the century, they have mostly been replaced by maize which, however, is more demanding in terms of moisture and soil fertility. As a result, yields tend to be low. In the drier parts of CL5 and in the ranching zone (CL6), livestock activities are supplemented by marginal food crop production of drought-resistent crops such as millet, sorghum and grams. Stock rearing is mainly for subsistence purposes and most of the farmers in the hinterland are organized in so-called group ranches. Land ownership is vested in the Group Ranch Committee and the individual families have the right of use.

The proportion of the area under food crops on the smallholdings in the more humid parts of Kwale and Kilifi is generally low, resulting in a relatively low degree of food selfsufficiency among the farming population. In the drier parts of the districts, on the other 
hand, the frequent occurrence of drought is a continuous threat to the food security of the farming families living there.

The size of the holding, the type of farm enterprise and cropping pattern are the main determinants of agricultural production. Yield levels, and consequently incomes, are generally low. At district level, figures are available regarding crop yields in the 1981-85 period in Kilifi District for the three main food crops, maize, sorghum and cassava. Firstly, yields differ very much in different years. For instance, productivity of local maize was $300 \mathrm{~kg} / \mathrm{ha}$ in 1982 , but $1200 \mathrm{~kg} / \mathrm{ha}$ in 1984 . Figures for sorghum in these years were 250 and $650 \mathrm{~kg} / \mathrm{ha}$ respectively. Secondly, yields of improved maize varieties were much higher - 1.5-1.9 times - than those of the local maize which is grown by the large majority of the smallholder farmers (but improved maize also requires more inputs). Thirdly, cassava harvests show an inverse relation with yields of annual food crops such as maize and sorghum. In a 'poor' year like 1982, twice as much cassava was harvested than in a 'good' year like 1984. This indicates the importance of cassava as a 'survival crop' (MOA 1985; 1986; MENR 1984a).

There are further differences in crop yields in relation to agro-ecological zones, soil types, farming inputs, etc. Waaijenberg (1994) found large differences in maize yields, between villages as well as within four villages in the southern central part of Kilifi District in the 1981-84 period. One remarkable finding was that there appeared to be little correlation between maize yield and main agro-ecological zone (i.e. mean annual rainfall). All villages did relatively well in 1981, when the long rains were well distributed. But the next year yields were low, not because of lack of rain but because rains were excessively heavy. In the latter year, there were important differences in crop yields $(\mathrm{kg} / \mathrm{ha})$ between the various farms in each village. How to explain these differences is not at all clear, but productivity is generally low for a number of reasons. There are the limiting physical features such as unreliable rainfall, poor soils, destruction by wildlife; the economic and financial constraints such as low prices for cash crops, lack or unawareness of credit facilities and the unfavourable infrastructural characteristics such as inaccessability of markets due to poor roads, tolls like the Likoni ferry; and shortage of storage facilities. Furthermore, there are limitations of a socio-cultural nature, notably traditional farming practices, with their poor levels of crop husbandry, low degree of adaptation of improved crop varieties and the limited use of external farm inputs, but also more pernicious factors like an often noted lack of motivation among the local population. Last, but not least, there are serious labour constraints that have to do with the health status of the population but also with actual shortage of labour (MENR 1984a; 1984b).

\subsection{Farm Labour}

Because of the seasonal distribution of rainfall, discussed before (p. 33), there is only one growing period in the coastal plain, while inland two harvests may be possible, although the short rains are often too marginal and unreliable to make a second planting successful. 
Land preparation for maize cultivation starts in February, before the start of the long rains (Figure 5). Seeding is concentrated in the following two months, but especially in March. The first weeding follows shortly afterwards (April-May). This is also the time that land preparation for beans and cowpeas is done, followed by seeding in June. Usually, these crops are interplanted with maize. Cassava is planted as well. From June to August the harvesting of the maize takes place, with a distinct peak in July. The first beans are harvested at this time. Some farmers - but certainly not all - start land preparation and seeding for a second maize crop. The following months, i.e. from September to January, are relatively lean, with such activities as weeding and harvesting of beans and cowpeas and the possible care of a second maize crop. It is during this period that harvesting of tree crops like cashewnuts and citrus also takes place (coconuts are harvested the whole year round). In sum, farming activities are mainly concentrated in the March-July period, i.e. partly during the rainy season. However, weeding of maize, a heavy task in terms of energy expenditure and also in man hours, is by far the most labour-consuming task (Vervoorn \& Waaijenberg 1986). In other words, the period between, roughly, mid-April to the end of June can be considered as the annual labour peak in this part of Kenya.

Nearly all cultivation activities for annual crops - planting, weeding, harvesting - are done by women and the maize hectarage per household is related to the number of women (mothers, wives, daughters) on the farm (Waaijenberg 1993). Men used to be responsible for the clearing of new fields, cutting and burning of trees and shrubs, but "nowadays most land preparation is done by women who, because the men are absent doing off-farm work, constitute more than three-quarters of the labour force." (Waaijenberg 1994, 170).

Besides the cultivation of annual crops, women fulfil a whole range of activities which are centred around the homestead, generally assisted by the girls. These tasks consist of cleaning the house and the courtyard, cooking, washing, making fire, collecting firewood, fetching water, collecting vegetables, pounding grain, grinding, milking, winnowing, and taking care of the young children. Especially collecting firewood and fetching water can be

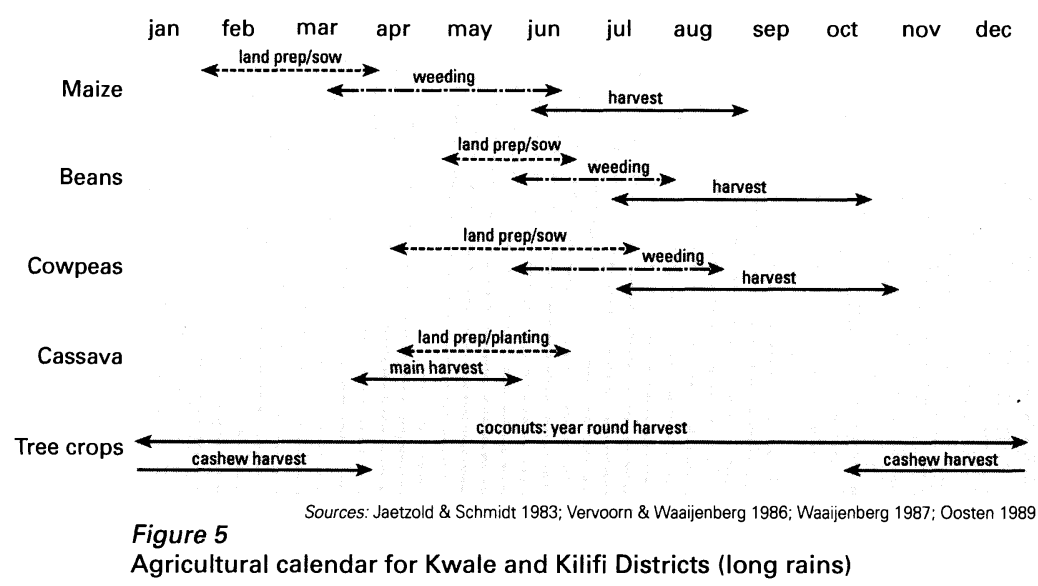


very burdensome tasks. In one household sample in Coast Province, fifteen per cent reportedly had to cover more than four miles to obtain water in the dry season (Geist 1981). For over half of the farm households in the two districts, the nearest water source in the dry season is at least two kilometres from the house, compared with a distance of onequarter of a kilometre in Kenya as a whole. The situation is better in the wet season, although more than 10 per cent of the households are still at least two kilometres from the nearest water source (CBS 1983). Fetching water is a major daily task but there are also other activities with which, during peak labour periods, the whole family - but the women in particular - have a busy time:

\begin{abstract}
Women wake up slightly later than men. They sweep the houses and courtyards, milk cows and prepare breakfast for the children before joining their husbands on the farm. During peak-labour seasons, boys and girls also wake up almost at the same time as their parents and all go to do various jobs on the farm. During such seasons, lunch is prepared and eaten on the farm. It is only after five in the evening that the family returns home after a day's work. On returning to the village, women and girls continue with household activities like splitting of firewood, pounding and winnowing of grain (rice, maize or sorghum), grinding, fetching water and cooking dinner. Men and boys do such activities as tapping palm wine, felling coconut fruits, and checking on cattle, sheep and goats to ensure that they have been properly grazed and none is missing from the fold. (Were, Nyamwaya \& Ipu 1986, 30)
\end{abstract}

\title{
3.8 Off-Farm Employment
}

Where agricultural opportunities are limited, off-farm employment is essential for making a living. However, employment opportunities in the region are limited as well, especially in the dry hinterland where, in the mid-1970s, only 6.4 per cent of household incomes was derived from regular employment, against 15.9 per cent in the coastal strip (Geist 1981). In the first half of the 1980s, less than 20 per cent of the potential labour force in Kwale and Kilifi Districts was engaged in wage employment (MENR 1984a; 1984b). Most employment is to be found in Mombasa. During the 1980s, taking Kwale, Kilifi and Mombasa Districts together, more than three-quarters of the wage employment in the modern sector was in Mombasa, 14 per cent in Kilifi and 9 per cent in Kwale (CBS 1990).

As a consequence migration is often necessary to find work and many wage labourers in Kwale and Kilifi Districts leave their homesteads to work in Mombasa or somewhere else in the coastal strip (i.e. in the hotel areas or in towns like Kilifi and Malindi). Only people from areas with good communications to one of these places are able to commute to their work daily and live at home on the farm. This is usually not the case for workers from the hinterland. Women often engage in vipande, i.e. casual labour for other farmers, especially land preparation and weeding.

Table 6 gives the household income situation in Coast Province in 1974-75. Only onequarter of the total income was derived from the farm, in the wetter as well as the drier parts (although the value of the farm operating surplus in the wetter areas was substantially 


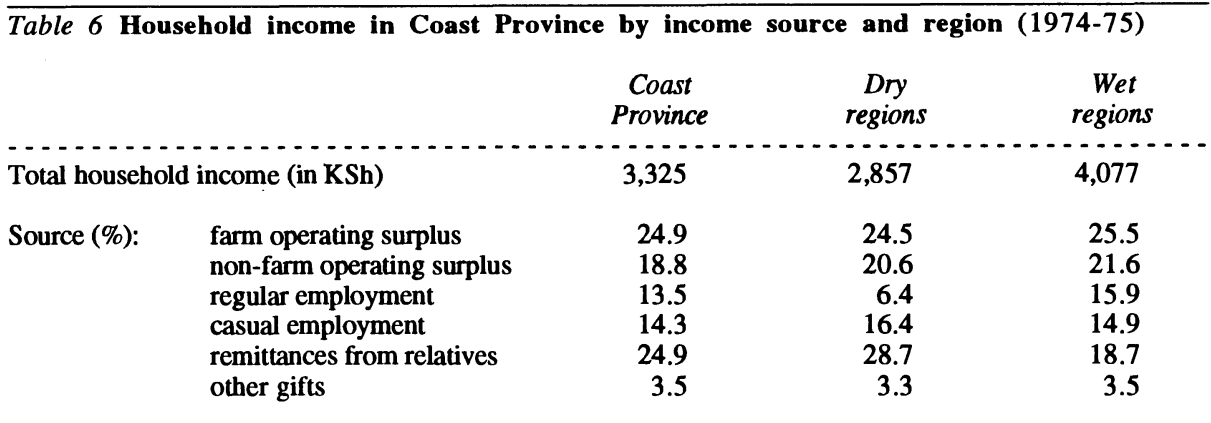

Source: Geist 1981, 185.

higher because total household incomes were much higher there). The share contributed by wages and remittances amounted to more than 50 per cent.

Figures for 1981/82 reveal a declining importance of farming (33 per cent in both Kwale and Kilifi Districts) and a growing importance of wage labour: salaries and wages contributed 45 per cent and 43 per cent of the average household income in Kwale and Kilifi, respectively (CBS 1988).

\subsection{Food Consumption, Nutritional Status and Health}

The degree of food self-sufficiency is low compared with the rest of Kenya. Geist (1981), using data from the Integrated Rural Survey of 1974-75, calculated the average value of own production and the value of total food consumption of rural households. She found that, thus calculated, the rate of food self-sufficiency in Coast Province was only 25.6 per cent, compared with 42.5 to 52.6 per cent in provinces like Central, Nyanza and Western. She also found a clear difference in the rate of food self-sufficiency in the coastal strip (17.3 per cent) and the hinterland (34.6 per cent). Carlsen (1980) reported that households in Kikoneni had to purchase 83.7 per cent of the total consumptive food. Compared with three other samples in Taita Taveta, Kisumu and Kisii Districts, this was a high proportion. Finally, Waaijenberg (1994) measured the rates of self-sufficiency in four inland villages in Kilifi District, with average annual rainfall ranging from 850 to $1130 \mathrm{~mm}$. He found a clear relationship with annual rainfall: the rate of maize self-sufficiency ranged from about 50 per cent in the wettest village to about 32 per cent in the driest village. Maize availability also varies with the time of the year. Data for 1982 and 1983 show that immediately after harvesting, 75 to 95 per cent of the households in the same four villages were eating maize from their own stock. In January, this had dropped to about one-third and one-fifth respectively. During the three months before the next harvest, nobody in the 'driest' village had any maize left in stock. Hence, a large proportion of the food consumed in the two districts must somehow be purchased, particularly in the coastal strip. This dependency on food 
purchases means that people must have sufficient amounts of money at their disposal to feed themselves and their families.

It is no surprise that under these conditions with great risk of harvest failure, serious food shortages are likely to occur. Herlehy (1983) was able to identify at least 10 famines over the period 1880-1960, when there was such a scarcity of food, so widespread or extreme in character that a significant proportion of the population in the afflicted areas was faced with the threat of starvation. He calls the famines by their Swahili names which usually refer to either the cause (fierce sun, locust plague, government fines) or the measures reverted to by the population (selling jewelry, foraging in the wild, food relief).

The health and nutrition situation generally reflects these circumstances. The most widespread disease in Kwale and Kilifi Districts is malaria, together with anaemia, diarrhoea and malnutrition (Boerma \& Bennett i.p.). Figures presented by Masai (1983) and Blankhart (1982) indicate high rates of child morbidity and mortality compared with other provinces. The number of hospital admissions of children with severe forms of proteinenergy malnutrition in Coast Province in 1966-1968 was twice as high as in Eastern and Rift Valley Provinces and 2.5 times as high as in Nyanza and Western Provinces. The rate of deaths in Coast Province due to malnutrition was 2-5 times higher than in the other provinces.

In 1982, the two districts had the highest percentage of children with low heights in Kenya. Kilifi District ranked first with $\mathbf{4 2 . 1}$ per cent stunted children, Kwale second with 38.5 per cent. In 1987 the two districts ranked second and third nationally (Kilifi: $39.3 \%$; Kwale: $42.8 \%$ ). Concerning the percentages of wasted children (low weight-for-height), in 1982 Kilifi ranked third (5.1\%) and Kwale fifth (4.9\%), the national figure being 3.0 per cent. But in 1987 the figures for the two districts deviated little from the national mean (CBS 1983; 1991).

The seasonal character of certain diseases among children is occasionally aggravated. During the dry season(s) there is a lack of pure drinking water and sanitation, which, combined with general malnutrition, causes periodic occurrences of gastroenteritis and "considerable mortality and morbidity among children" (MENR 1984b). Were et al. (1986) also state that most deaths occur from October to April and in June and July.

Other researchers indicate that malnutrition and related diseases, as well as morbidity and mortality are less severe in the drier and more thinly populated hinterland than in the wetter and relatively densely populated areas nearer to the coast. Blankhart (1982) compared young children from four groups in Kwale District. Among relatively prosperous farmers near the coast, malnutrition appeared to be limited. On the other hand, among households in the dry hinterland, the number of stunted children was found to be 66 per cent, while all children had an upper arm circumference of less than 90 per cent of the age standard. Malnutrition is not only related to poverty, but also to ignorance regarding the nutritional needs of children and traditional food practices and finally, it has been noted "that even within families with high income, malnutrition is still prevalent because of ignorance in preparing diets for the family" (MENR 1984a, 166). 


\subsection{Study Method}

The general purpose of the present study was to contribute to the knowledge regarding climatic seasonality and food security among rural populations. A second aim was to collect information on food practices and nutritional conditions among the population of Coast Province. The specific objective was firstly to study seasonal variations in food consumption and nutritional status among the rural populations in the coastal lowlands, and secondly whether and how seasonal variations, if existent, are related to environmental factors, notably differences that exist between agro-ecological zones and socio-economic differentiation among farming households.

The study areas are situated in Kwale and Kilifi Districts in the three agro-ecological zones CL3-CL4-CL5 (map 4, p. 36). Information on the population parameters and the agro-ecological characteristics of the areas has already been given in Table 1 (p. 30) and Table 5 (p. 39). A brief description of each area is further given in Appendix 2 (p. 110).

For each research area, a map was available identifying about 150 households in a subarea. The study sample consisted of every third household in the mapped area, i.e. 50 households in each area. In total 297 households, numbering a total of 2,650 persons, were sampled. Among this population 2,314 were full-time resident, 107 were part-time resident, while 229 were in fact non-resident. The resident population was composed of 94 elderly people over 60 years, 784 adults of 20-59 years, and 1435 youngsters under twenty. The survey procedures are described in Appendix 3; the sample composition is listed in Appendix 4, 5 and 6.

Five survey rounds were conducted in the period between June 1985 and November 1986 so that each household was visited five times, at about four month intervals. The material collected during the first round concerned household and demographic characteristics, agriculture, off-farm employment, food consumption and nutritional status. The information collected during subsequent rounds covered household events since the previous

\begin{tabular}{|c|c|c|c|c|c|c|c|c|}
\hline \multirow{2}{*}{$\begin{array}{l}\text { survey } \\
\text { round }\end{array}$} & \multirow{2}{*}{\multicolumn{2}{|c|}{$\begin{array}{c}\text { period } \\
\text { of data } \\
\text { collection }\end{array}$}} & \multicolumn{5}{|c|}{ data schedule* } & \multirow{2}{*}{$\begin{array}{c}\text { agricultural } \\
\text { season } \\
\text { covered }\end{array}$} \\
\hline & & & hsng & demog & farm & fdcons & nutr & \\
\hline$\ldots$ & $\ldots$ & - - & 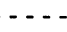 & 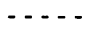 & 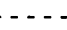 & $\ldots$ & $\cdots$ & $\ldots$ \\
\hline 1 & jul/aug & 1985 & + & + & + & + & + & short rains $1984 / 85$ \\
\hline 2 & nov/dec & 1985 & - & - & + & + & + & long rains 1985 \\
\hline 3 & feb/mar & 1986 & - & - & + & + & + & short rains $1985 / 86$ \\
\hline 4 & may/jun & 1986 & - & - & + & + & + & long rains $1986^{* *}$ \\
\hline 5 & sep/oct & 1986 & - & - & + & + & + & long rains 1986 \\
\hline
\end{tabular}

\footnotetext{
* + = full information recorded, - = only changes recorded;

hsng = housing characteristics; demog = demographic characteristics \& employment; farm = farming activities; fdcons = food consumption; nutr = nutritional status

** pre-harvest
} 
interview and consisted of a full interview schedule with the exception of housing and demographic characteristics for which only changes were inquired after (Table 7).

The results regarding the socio-economic conditions among the study population are presented in Chapter 4. The findings in respect of food consumption and nutritional status are discussed in Chapters 5 and 6. 


\section{Socio-Economic Conditions*}

The conditions among the study population are discussed in the three subsequent sections on demographic characteristics, agricultural practices and employment conditions. The results are, in first instance, presented by research area to give some insight into the variation that occurs between areas. In the last section on household income, the results are presented by different agro-ecological zones and different income classes.

\subsection{Demographic Characteristics and Living Conditions}

\section{Demographic characteristics}

There is considerable difference in household size between areas, although the ratio adults/children generally remains much the same. The largest households are in the inland area in Kilifi District, almost twice the size of the average household in the other research areas (Table 8). The largest single household with no fewer than 47 members was found here. Households are smallest in the area situated in the coastal plain in Kwale District. For purposes of this survey which is concerned with food production and food consumption. household size is calculated as the number of consumer units (cu) in each household 13 This recalculation does not affect the previously noted differences.

* This chapter is a revised version of Foeken, Leegwater, Niemeijer, Veerman \& Hoorweg (1989) 


\begin{tabular}{lcccccccc}
\hline Table 8 & Average household size by research area & & & & \\
& & Total & Kwale & Kilifi & Kwale & Kilifi & Kwale & Kilifi \\
& N=(297) & CL3 (50) & CL3 (50) & CL4 (48) & CL4 (50) & CL5 (49) & CL5 (50) \\
Household members & 8.9 & 6.0 & 10.7 & 6.7 & 8.6 & 7.4 & 14.0 \\
Consumer units & 5.8 & 4.2 & 6.6 & 4.5 & 5.4 & 5.0 & 9.0 \\
Child/adult ratio & 1.2 & 1.1 & 1.4 & 1.4 & 1.2 & 1.2 & 1.0
\end{tabular}

The average household size in the Kilifi areas is 7.0 consumer units, which is larger than in the Kwale areas which average $4.6 \mathrm{cu}$. The difference in household size between the districts is the result of differences in household organization. Compared with the households in Kwale, households in the Kilifi areas are generally more complex in nature, due to polygamy and patrilocal residence. Among the Chonyi, Kauma and Giriama in Kilifi, polygamy is quite common with co-wives living together in the same compound. In almost half of the Kilifi households the head had more than one wife. There are also more extended households, where married sons remain members of the parents' household, so that households may include more than one married couple of the same or different generations. In fact, only 24 per cent of the Kilifi households were of the nuclear type, i.e. exclusively consisting of man, wife and children. The very large households, as in Mikamini, usually show a combination of the above. In the Kwale areas, only 20 per cent of the heads of households were married polygamously, and only 44 per cent of the households were not nuclear in kind.

Nine per cent of the total population was reported to be absentee or non-resident i.e. usually residing elsewhere. Another four per cent was part-time resident, having been absent for at least two weeks during the last three months (Appendix 4). It was already mentioned that Kwale and Kilifi Districts have low sex ratios because many men work outside the districts, for example in Mombasa. The figures in Table 1 (p. 30) already showed that males are underrepresented in all of the sub-locations where survey areas are situated. In fact, of the adult men forty percent was not permanently living in the household (Table 9). Among the women this was only 5 per cent. The lowest number of absentee males is found in the CL3-Kwale area (18\%) due to the fact that employment opportunities are near at hand. The differences between the research areas in this respect are further discussed in the section on off-farm employment (p. 61). In general, the number of absent males tends to be

Table 9 Male residency by research area (\%; adult males, 17 years and older)

$\begin{array}{ccccccc}\begin{array}{c}\text { Total } \\ \text { N=(652) }\end{array} & \begin{array}{c}\text { Kwale } \\ \text { CL3 (77) }\end{array} & \begin{array}{c}\text { Kilifi } \\ \text { CL3 (135) }\end{array} & \begin{array}{c}\text { Kwale } \\ \text { CL4 (75) }\end{array} & \begin{array}{c}\text { Kilifi } \\ \text { CL4 (100) }\end{array} & \begin{array}{c}\text { Kwale } \\ \text { CL5 (88) }\end{array} & \begin{array}{c}\text { Kilifi } \\ \text { CL5 (177) }\end{array} \\ 60.4 & 81.8 & 51.9 & 72.0 & 54.0 & 67.1 & 53.1 \\ 39.6 & 18.2 & 48.2 & 28.0 & 46.0 & 33.0 & 46.9 \\ 100.0 & 100.0 & 100.0 & 100.0 & 100.0 & 100.0 & 100.0\end{array}$

full-time residents part-time \& non-residents 
high in the areas where households are largest. Two speculations can be made as to why this should be so: large households may have greater flexibility with respect to the division of labour and some members can migrate without adverse consequences for agricultural production or, conversely, households can be large because many members are living and working elsewhere, providing a more or less regular source of income.

The level of education among the adult population is lower than that of Kenya as a whole. More than half of the adults had not received any formal education; this is particularly so among the women, of whom three-quarters had no formal education. The men were generally better educated: 60 per cent had partly followed or had completed primary education. Men in the less remote areas were generally better educated than in the coastal hinterland. People who went further than primary school were few: only ten per cent of the men and three per cent of the women. Generally, the better educated men are the ones who leave home to find off-farm jobs: 24 per cent of the part-time/non-residents had followed more than primary education.

\section{Living conditions}

Houses in the rural areas of Kwale and Kilifi are mainly of two types, the Mijikenda and the Swahili house. The traditional Mijikenda house consists of a frame of poles and branches, from top to bottom covered with grass. Gradually, low mud and wattle walls have been introduced to support the upper structure while palm leaves may be used to replace grass as roofing material. The house is generally divided in two parts, one area being used for cooking and social activities, the other for sleeping and private activities (Andersen 1977). The Swahili house also consists of a wooden frame, but the walls are filled with mud in which small coral stones are mixed, while the roof is thatched with dried coconut palm leaves (makuti). Generally, it has several rooms with a common verandah. Although houses with grass or makuti roofs are cooler, they tend to accumulate more dust and insects. More 'modern' houses tend to have roofs of corrugated iron sheets. People who can afford it will build walls from coral stone and paved floors, but these are few (Beinum $e t$ al. 1985).

Households usually occupy a mixture of living houses, kitchen place and sheds of various kinds. The head and/or the first wife live in the 'main house'. Where necessary, there are houses for second wives, for adult children or kin of the head of the households, and their dependents. Boys, once they become sexually mature, are no longer allowed to sleep under the same roof as their mothers, and they build smallish structures, so-called

Table 10 Houses, rooms and occupants by research area (averages)

\begin{tabular}{lccccccc} 
& $\begin{array}{c}\text { Total } \\
\text { N=(297) }\end{array}$ & $\begin{array}{c}\text { Kwale } \\
\text { CL3 (50) }\end{array}$ & $\begin{array}{c}\text { Kilifi } \\
\text { CL3 (50) }\end{array}$ & $\begin{array}{c}\text { Kwale } \\
\text { CL4 (48) }\end{array}$ & $\begin{array}{c}\text { Kilifi } \\
\text { CL4 (50) }\end{array}$ & $\begin{array}{c}\text { Kwale } \\
\text { CL5 (49) }\end{array}$ & $\begin{array}{c}\text { Kilifi } \\
\text { CL5 (50) }\end{array}$ \\
Living houses per h.hold & 2.1 & 1.2 & 2.8 & 1.3 & 2.2 & 1.9 & 3.3 \\
Rooms per household & 3.5 & 3.5 & 4.7 & 3.2 & 2.9 & 2.7 & 4.2 \\
Occupants per room & 2.8 & 1.9 & 2.5 & 2.4 & 3.3 & 3.0 & 3.5 \\
\hline
\end{tabular}


boys' houses, which they usually share with other boys. Where houses are more spacious, grown-up boys may be given a separate room. Girls of that age do not build their own houses but often sleep in the house of an older female family member.

On average, the Kilifi compounds have twice the number of living houses as the Kwale compounds (Table 10). However, in Kilifi the smaller Mijikenda house is more common and the number of rooms per house is smaller than in Kwale, where the Swahili type of house dominates. In all, the total number of rooms per household is still larger in Kilifi than in Kwale, although this is not sufficient to compensate for the much larger population. Consequently, densities per room are higher than in Kwale. There are further differences between individual research areas.

The quality of the materials used in the construction of houses is decided by three factors: tradition, the wealth of the household and the presence of local building materials. Hence, the structures differ strongly among agro-ecological zones. In the coconut-cassava zone (CL3), with many coconut palms, nearly all the roofs are made of palm leaves, while in the livestock-millet zone (CL5) half of the roofs are made of grass. Mud mixed with crushed coral is generally used for walls in the coconut-cassava and cashewnut-cassava (CL4) zones. Grass or makuti walls are still found in the livestock-millet zone. Floors usually consist of earth. The best houses in terms of construction materials are found in the CL3 and CL4 areas in Kwale. In these areas households tend to have higher incomes as shown later.

Sanitation is another important element of living conditions. The presence of clean drinking water and adequate waste disposal differ among agro-ecological zones (Table 11). In the CL3 areas, water is usually available from local wells, the areas in CL4 draw water from a pipeline/borehole. In these areas there is little seasonal difference in water access, although problems may occur when there is a breakdown. In the CL5 area, however, the situation is different. People depend on surface water, but these sources usually dry up during the dry season. During these periods, many households have to rely on improved water sources at great distances from the compounds, as in the case of the CL5 area in Kilifi. During the wet season, about three-quarters of the households were within ten minutes walking distance from some pond, but during really dry periods nearly all households were more than $25 \mathrm{~km}$ from a water source, namely the pipeline in Ganze, from where the water has to be transported by various means. The quality of the water may be better at this

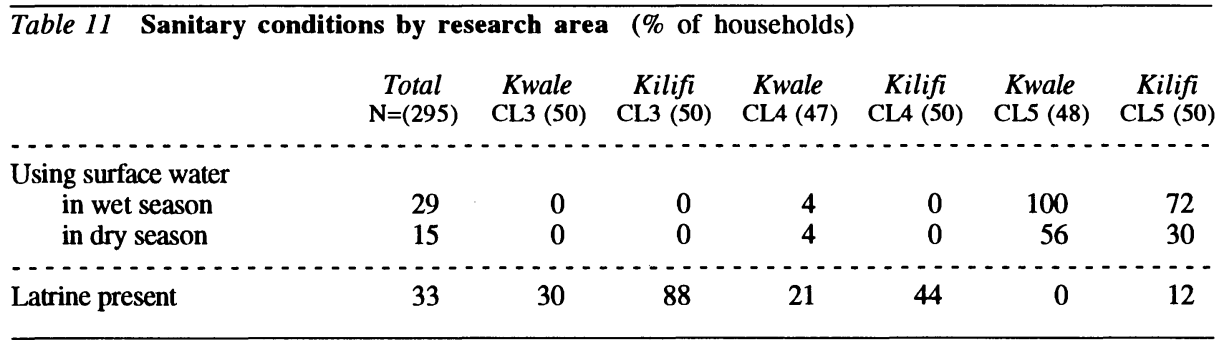


time than the surface water in the wet season. However, the amount of water available is likely to be less and not enough for good household hygiene.

Overall, only one-third of the households had a latrine, which is a low percentage compared with other parts of Kenya. Latrines are fewer in the drier areas (Table 11). The difference between zones may be explained by the lower population density in the drier areas, and possibly by a lesser influence of government health and sanitation services.

\subsection{Agriculture 14}

Farm size, land use and farm labour

On average, farmers had 8.2 acres (3.3 ha) at their disposal (Table 12) which is much less than reported earlier (p. 39). There are large variations concerning farm size, not only between but also within the research areas. For instance, the smallest farm consisted of 0.4 acres, the largest one of 91 acres. In general, farms in the CL5 zone are larger than in the two other zones; in the CL5 area in Kilifi the average farm size is 21 acres. The exception to the trend is the CL3-Kwale area where the average farm size was relatively large (6.8 acres). In fact, the smallest farms were in CL3-Kilifi (2.8 acres), near Kaloleni, the study area with the highest population density, where a situation of land shortage can be said to exist.

Not all land was used for food crops. Where trees are planted, shade inhibits the growing of annual crops, while in the drier areas land lies fallow. One-third of the farm land, in one way or another, was used for the cultivation of food crops (Table 12). There are important differences between the districts. In the areas situated in Kwale, the acreage reserved for food crops amounted to about 35 per cent of the available land, leaving the remainder for other purposes. In Kilifi, however, in the CL3 and CL4 zone, more than 70 per cent of the land was reserved for food crops. In the CL3 area this must be related to the small farms. Farmers here sometimes even plant food crops amidst their trees. The households in the CL4 area have access to deeper fertile soils which are particularly suitable for maize cultivation. In the remaining CL5 area in Kilifi, farms are generally large, but only one-fifth of the land was in use for food crop cultivation.

Table 12 Farm size and land use by research area

$\begin{array}{ccccccc}\text { Total } & \text { Kwale } & \text { Kilifi } & \text { Kwale } & \text { Kilifi } & \text { Kwale } & \text { Kilifi } \\ \mathrm{N}=(297) & \text { CL3 (50) } & \text { CL3 (50) } & \text { CL4 (48) } & \text { CL4 (50) } & \text { CL5(49) } & \text { CL5 (50) }\end{array}$

\begin{tabular}{lrrrrrrr} 
Farm acreage / household & 8.2 & 6.8 & 2.8 & 4.1 & 5.0 & 9.4 & 21.0 \\
Food crop acreage / household & 2.8 & 2.4 & 2.0 & 1.4 & 3.8 & 2.9 & 4.4 \\
Farm acres under food crops (\%) & 34 & 35 & 69 & 35 & 77 & 30 & 21 \\
\hline
\end{tabular}

* Area ratio 15 
Most households had more than one plot; on average, 2.7 plots of agricultural land. Farms were most fragmented in the CL3-Kilifi area, with the result that the average distance to the plots was also the largest there (about 50 minutes walking). One of the possible coping mechanisms against the adverse effects of seasonality is the cultivation of plots in different agro-ecological zones. This hardly occurs as a mechanism at household level, although the possibility remains that it is used as an inter-household strategy, i.e. by polygamous and extended households that may split up at certain times of the year and temporarily move elsewhere 16

The figures above concern households, but household size differs considerably in the different research areas. Consequently, the available household labour also differs. After correction for age, off-farm employment and residency ${ }^{17}$, it was calculated that households had an average of 3.0 adult equivalents potentially available for farm labour, mainly consisting of women (Table 13). Not surprisingly, the households in the Kilifi areas had more farm labour available compared with the Kwale areas. When the ratio of available farm land and potential farm labour is calculated, there was an average of 2.7 acres per farm worker. The areas with the largest tracts of land per labour unit, i.e. the most extensive type of agriculture, were found in the CL5 areas. The rate was less in the CL4 areas, and again less in the CL3 zone, reflecting increasing population and agricultural intensification. There is, however, one exception, CL3-Kwale, where the rate was much higher than in the other CL3/CL4 areas, suggesting that land is underexploited here. There is little difference between the districts.

The ratio of land in use for food crop production averaged at 0.9 acres per farm labour equivalent. In this respect, the differences are much smaller. No systematic differences exist between agro-ecological zones although there are considerable differences between the individual research areas.

Table 13 Farm labour by research area

$\begin{array}{ccccccc}\text { Total } & \text { Kwale } & \text { Kilifi } & \text { Kwale } & \text { Kilifi } & \text { Kwale } & \text { Kilifi } \\ \mathrm{N}=(297) & \text { CL3 (50) } & \text { CL3 (50) } & \text { CL4 (48) } & \text { CL4 (50) } & \text { CL5 (49) } & \text { CL5 (50) }\end{array}$

\begin{tabular}{llllllll} 
Farm labour (adult equivalent) & 3.0 & 1.9 & 3.5 & 2.0 & 2.9 & 3.0 & 4.7 \\
Acres / farm labour equivalent * & 2.7 & 3.6 & 0.8 & 2.1 & 1.7 & 3.2 & 4.5 \\
Acres food crops/farm labour eq. & 0.9 & 1.3 & 0.6 & 0.7 & 1.3 & 1.0 & 0.9 \\
\hline
\end{tabular}

* Area ratio

\section{Food production}

The long rains of 1985 and the short rains of 1985/86 were not particularly favourable but not particularly unfavourable either. The total rainfall almost equalled the 'normal' amount, but the distribution over the year was irregular, although this in itself is not an uncommon feature. At the beginning of the long rains the maize crop germinated satisfactorily but was partly destroyed by heavy rainfall in May, while outbreaks of pests (root beetles, rodents) 
caused damage in parts of Kilifi District. The short rains came late, resulting in late planting. These rains were untimely, in some parts lasting for only two weeks followed by prolonged dry periods so that there was no crop to be harvested 18

Nevertheless, almost 30 per cent of the farmers had some cereal harvest from the second growing season, although this contributed only 13 per cent to the total harvest of that year. The CL5-Kilifi area is an exception, however, since the bulk (80\%) of the maize harvest was, in fact, realized during the second growing season, something which seems not to be exceptional according to local information. The long rains of $1985 \mathrm{had}$ been poor in this area, making the harvest of the short rains relatively more important.

Data on the production of the two dominant crop types - cereals and cassava - are presented in Table 14. Maize is the main staple crop, followed by cassava and, to a lesser extent, beans, rice and bananas. Sorghum and millet were hardly grown; not even in the livestock-millet zone where only five per cent of the farmers did grow these drought-resistant crops. One-tenth of all households (30 farmers) cultivated some rice, mostly in CL3Kwale where farmers grow either maize or rice in seasonal swamps (Oosten 1989).

Table 14 Cereals and cassava production by research area (1985/86)

$\begin{array}{ccccccc}\text { Total } & \text { Kwale } & \text { Kilifi } & \text { Kwale } & \text { Kilifi } & \text { Kwale } & \text { Kilifi } \\ \mathrm{N}=(297) & \text { CL3 (50) } & \text { CL3 (50) } & \text { CL4(48) } & \text { CL4 (50) } & \text { CL5 (49) } & \text { CL5 (50) }\end{array}$

CEREALS

$\begin{array}{lrrrrrrr}\text { H.holds growing cereals (\%) } & 80 & 62 & 80 & 90 & 92 & 94 & 62\end{array}$

$\begin{array}{lrrrrrrr}\text { Average production (kg./h.hold) } & 352 & 37 & 225 & 279 & 784 & 554 & 234\end{array}$

CASSAVA

$\begin{array}{lrrrrrrr}\text { H.holds growing cassava (\%) } & 74 & 92 & 88 & 85 & 80 & 73 & 24 \\ \text { Average no. plants / h.hold } & 363 & 675 & 410 & 276 & 436 & 320 & 56\end{array}$

An average of $350 \mathrm{~kg}$ of cereals was harvested per household in 1985, of which $340 \mathrm{~kg}$ consisted of maize. This amounts to $60 \mathrm{~kg}$ per consumer unit. There are considerable production differences, ranging from $780 \mathrm{~kg}$ cereals per household in CL4-Kilifi, to a meagre $40 \mathrm{~kg}$ per household in CL3-Kwale. The areas with the highest agricultural potential - the two CL3 areas - show the lowest production of cereals, together with CL5-Kilifi, the low potential area in Kilifi. In CL3-Kilifi, this must be due to the relatively small farm size, since the production per acre in this area is relatively high (Table 19, p. 60). One-fifth of the households did not grow any cereals. In two quite disparate areas this is even the case for one-third of the households. In both areas, off-farm activities form the major part of the total resource base, as shown later.

The low cereal production in the CL3 area in Kwale is somewhat compensated by cassava cultivation. A large number of households cultivated cassava while the average number of cassava plants was the highest (Table 14). The local inhabitants, the Digo, are known as 'cassava growers' but it must be noted that in the other areas many households 
cultivated cassava as well, while many Digo households rely on the purchase of maize flour for their food requirements, as we shall see later.

Beans are not commonly grown. This crop was cultivated in only one-third of all households and in very small quantities. It is noteworthy that the leaves, which are consumed as a vegetable, are locally considered more important than the pulses. Over half of the households had one or more banana trees, almost solely for home consumption. A few farmers in CL3-Kwale had a large number of banana trees for commercial purposes.

\section{Food self-sufficiency}

Food production from the household's own farm is an important factor in food security. An estimate was made of the degree to which each household was able to fulfill its food requirements with staple foods (cereals, cassava, beans, bananas) from own cultivation 19 On average, only 45 per cent of the energy requirements was covered (Table 15), thus leaving a 'deficit' of 55 per cent. In other words, in 1985/86 more than half of the staple foods had to be obtained from other sources, food purchases in particular. Two areas CL4-Kilifi and CL5-Kwale - stand out positively, being roughly 75 per cent self-sufficient.

Table 15 Food self-sufficiency by research area $(1985 / 86)$

\begin{tabular}{|c|c|c|c|c|c|c|c|}
\hline & $\begin{array}{l}\text { Total } \\
\mathrm{N}=(297)\end{array}$ & $\begin{array}{l}\text { Kwale } \\
\text { CL3 (50) }\end{array}$ & $\begin{array}{c}\text { Kilifi } \\
\text { CL3 (50) }\end{array}$ & $\begin{array}{l}\text { Kwale } \\
\text { CL4 (48) }\end{array}$ & $\begin{array}{c}\text { Kilifi } \\
\text { CL4 (50) }\end{array}$ & $\begin{array}{l}\text { Kwale } \\
\text { CL5 (49) }\end{array}$ & $\begin{array}{c}\text { Kilifi } \\
\text { CL5 (50) }\end{array}$ \\
\hline $\begin{array}{l}\text { verage degree of } \\
\text { od self-sufficiency }(\%)\end{array}$ & 46 & 36 & 32 & 43 & 77 & 72 & 14 \\
\hline $\begin{array}{l}\text { rcentage of households with } \\
\text { od self-sufficiency }<50 \%\end{array}$ & 68 & 76 & 80 & 63 & 56 & 37 & 96 \\
\hline
\end{tabular}

As regards the degree to which the households were able to meet their respective (staple) energy requirements, only 10 per cent were producing sufficient staple foods to feed the members throughout the year. No less than 70 per cent of the households produced insufficient food crops to meet even half of the energy requirements. This is remarkable because all households in the survey had smallholdings, as a rule more than one acre. Regarding the differences between the research areas, the same observations can be made as above. Even in the two areas with the highest food production, only one in three households produced more than 75 per cent of staple food requirements. In the two other Kwale areas, more than half of the households produced less than half of their requirements. In the two other Kilifi areas conditions are even worse: half or more of the households produce less than onequarter of their requirements. The low degree of food self-sufficiency makes households dependent to a large extent on income from cash crops, livestock and off-farm employment. 
In food energy terms, cereals contributed 63 per cent to household food production, cassava 24 per cent, and bananas a further 11 per cent. Beans contributed only marginally. Cereals accounted for more than half the food energy in four research areas; only in the CL3-Kwale area did the principal subsistence production come from another crop, cassava 20

\section{Cash crops}

Cash crop cultivation faces the same ecological constraints as food crops, and mostly consists of tree crops which play an important role in the rural economy of the region. In suitable areas, coconut palms truly dominate, providing the tropical landscape characteristic of the Kenyan Coast. The palm is sometimes called the 'tree of life': the nuts can be used for home consumption or sold for copra production, the husks of the nuts may be used as fuel if firewood is scarce, the leaves are used as roofing material, and last but not least, the unopened spathes can be tapped for the production of palm wine (toddy). One tree can produce one or two bottles of 0.5-1 litre a day (Floor 1981). Until the selling of palm wine became illegal, this was an important means to tide farmers in the coconut belt over periods of food shortages (Herlehy 1983). In short, a coconut palm always yields something. Nevertheless, Waaijenberg $(1987,226)$ estimated the total annual income per palm at no more than sh.30 during the first half of the 1980s (tapping excluded), leading him to the conclusion that "one needs more than the average number of palms to cover [...] household needs".

The relevant data are summarized in Table 16, with figures on the percentage of households with trees and the average number of trees. Of all households, 60 per cent had coconut palms. There was an average of 33 producing trees per household. Another 54 per cent of the households owned cashewnut trees, but in comparison with coconut palms, the average number of producing trees was much lower: 16 per household.

Besides coconut palms and cashewnut trees, there is a range of other (potential) cash crops: citrus, mango (improved and local varieties), soursop, guava, pawpaw, passion fruit, pineapple, sugar cane, pepper, bixa, tobacco, etc. In general, these crops are of minor or no commercial importance, in terms of the number of households cultivating these crops as well as the average number of plants per household. Nevertheless, in a few households, substantial numbers were recorded.

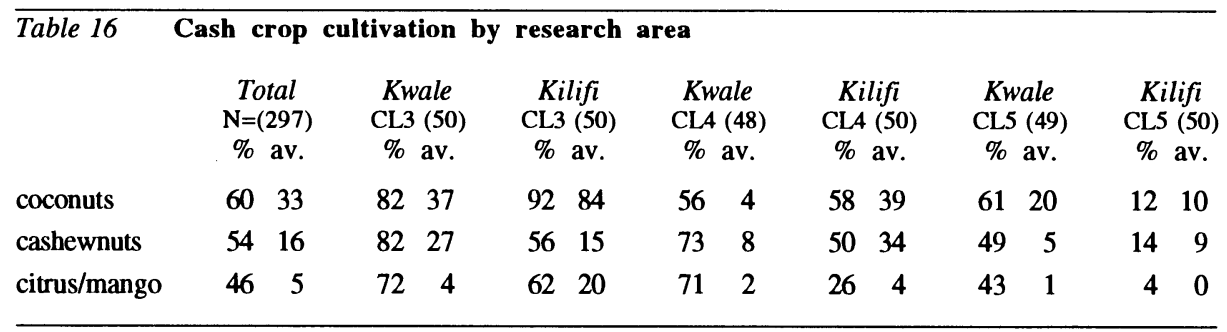

$\%$ = per cent households with trees (producing \& non-producing)

av. $=$ average number of producing trees per household 
The value of trees as a cash crop depends to a large extent on the possibilities of marketing, either when a market place is nearby (CL3-Kwale) or when connections with a market are favourable (CL3-Kilifi; CL4-Kwale). Elsewhere, traders or buyers of raw materials occasionally pass through, perhaps on a more or less regular basis. Places like CL5Kwale are located unfavourably. Perhaps that is one of the reasons why local varieties of mango, pawpaw, guava and custard apple are often not even harvested (Oosten 1989).

\section{Livestock}

Figures on livestock in the six research areas are presented in Table 17. On average, 18 per cent of the sampled households had one or more head of cattle, 41 per cent owned goats and/or sheep, while almost all households had some poultry. In general, livestock was more prevalent as the areas become drier, at least as far as cows and goats/sheep are concerned. However, there are important variations within the zones.

Because of the risks connected with annual cropping in zone CL5 and the few trees grown there, one would expect an economy mainly based on livestock. This, however, is only partly the case. Half the households in the two areas kept goats/sheep, and even fewer households kept cattle. In fact, the households that did not keep any livestock amounted to 38 per cent, while another 24 per cent kept fewer than two livestock equivalents as shown by the figures on distribution of all cattle, sheep and goats, pooled together.

Table 17 Livestock ownership by research area

\begin{tabular}{|c|c|c|c|c|c|c|c|}
\hline & $\begin{array}{c}\text { Total } \\
\mathrm{N}=(297)\end{array}$ & $\begin{array}{c}\text { Kwale } \\
\text { CL3 (50) }\end{array}$ & $\begin{array}{c}\text { Kilifi } \\
\text { CL3 (50) }\end{array}$ & $\begin{array}{c}\text { Kwale } \\
\text { CL4 (48) }\end{array}$ & $\begin{array}{c}\text { Kilifi } \\
\text { CL4 (50) }\end{array}$ & $\begin{array}{c}\text { Kwale } \\
\text { CL5 (49) }\end{array}$ & $\begin{array}{c}\text { Kilifi } \\
\text { CL5 (50) }\end{array}$ \\
\hline verage $\mathrm{LE} *$ / household & 4.7 & 0.8 & 0.7 & 2.8 & 0.9 & 7.2 & 15.6 \\
\hline $\begin{array}{l}\text { holds (\%): without livestock } \\
\text { with } 0.1-1.9 \mathrm{LE} \\
\text { with } 2 \text { or more LE }\end{array}$ & $\begin{array}{r}55 \\
27 \\
19 \\
100\end{array}$ & $\begin{array}{r}78 \\
16 \\
6 \\
100\end{array}$ & $\begin{array}{r}44 \\
42 \\
14 \\
100\end{array}$ & $\begin{array}{r}65 \\
25 \\
10 \\
100\end{array}$ & $\begin{array}{r}64 \\
28 \\
8 \\
100\end{array}$ & $\begin{array}{r}47 \\
22 \\
31 \\
100\end{array}$ & $\begin{array}{r}30 \\
26 \\
44 \\
100\end{array}$ \\
\hline
\end{tabular}

* LE=livestock equivalent; $1 \mathrm{LE}=1$ head of cattle $=7$ goats/sheep (poultry not included).

\section{Agricultural resources}

The annual value of each type of agricultural production was calculated per household (Table 18) 21 The total value of farming activities was highest in CL4-Kilifi and CL5Kwale. The contribution of food crops to the total value was in the range of 60-80 per cent, with one exception, CL5-Kilifi, where livestock contributed about 60 per cent. Cash crops contributed substantially to farm income only in the two areas in the CL3 zone. The two CL4 areas derived most of their agrarian income from food crops, with relatively low contributions from other activities. Households in the CL5 area in Kwale had a similar high income from food crops. Households in the two CL5 areas also realized contributions from 


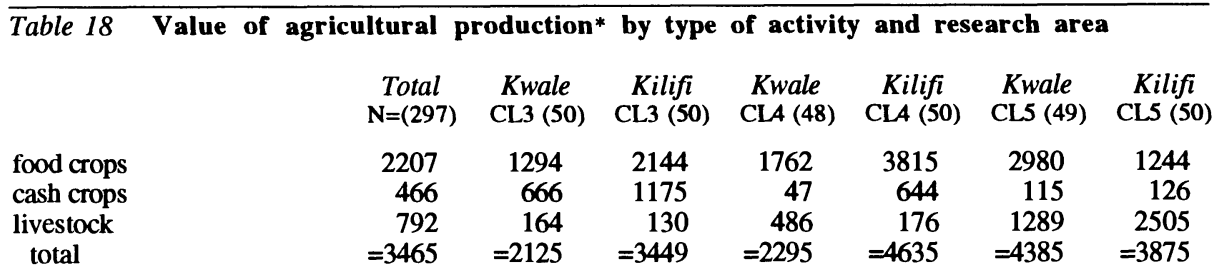

* sh/household/year; 1985/86

livestock. It appears that in respect of food crop production the CL5-Kwale area had more in common with the CL4 locations, but that in respect of cash crops and livestock it resembled the other CL5 location.

In Table 19, different measures of agricultural productivity are presented: production per household, per consumer unit, as well as the estimated returns per acre and per labour unit. The resulting figures reveal somewhat different patterns from the overall household figures. The households in the remote inland Kilifi area had the lowest agricultural income; in terms of sustenance of household members, averaging only sh.500 per consumer unit. The returns per acre and per farm worker were also low here, generally confirming the low agricultural potential of the area. At the other end, there are two areas with sh.1,000/cu or more from agriculture (CL4-Kilifi and CL5-Kwale). In these areas the productivity per worker was also relatively high but the productivity per acre differs: it was much higher in the CL4 area. Nevertheless, dependence on off-farm income is likely to be less in these areas, something which will be confirmed later on.

The remaining areas show a mixed picture. The figures for production per consumer unit fall in the same range, as do the figures for production per farm worker. However, the returns per acre differ considerably. In the CL3-Kilifi area, returns per acre were high, but returns per worker had dropped below those of the other areas as a result of the serious land scarcity in the area. In the two Kwale areas, the reverse situation existed, with somewhat higher returns per labour but low returns per acre, indicating extensive agriculture in zones that allow for more intensive cultivation, particularly in CL3-Kwale.

The six locations included in the survey were selected from the three main agro-ecological zones in the districts and it is evident that we face a complex situation with (1) agro-

\begin{tabular}{lccrrrrr}
\hline Table 19 & Agricultural productivity by research area (sh) \\
& Total & $\begin{array}{c}\text { Kwale } \\
\text { CL3 }\end{array}$ & $\begin{array}{r}\text { Kilifi } \\
\text { CL3 }\end{array}$ & $\begin{array}{c}\text { Kwale } \\
\text { CL4 }\end{array}$ & $\begin{array}{c}\text { Kilifi } \\
\text { CL4 }\end{array}$ & $\begin{array}{c}\text { Kwale } \\
\text { CL5 }\end{array}$ & \multicolumn{1}{c}{ Kilifi } \\
Production / household & 3465 & 2125 & 3449 & 2295 & 4635 & 4385 & 3875 \\
Production / consumer unit & 730 & 643 & 561 & 569 & 983 & 1139 & 488 \\
Return / acre * & 326 & 287 & 1169 & 447 & 895 & 328 & 65 \\
Return / labour equivalent * & 1151 & 1118 & 974 & 1165 & 1582 & 1467 & 830
\end{tabular}

* Area ratios (The returns per acre exclude livestock production). 
ecological variations between zones, in line with the classification and descriptions offered by Jaetzold \& Schmidt (1983); and (2) agro-ecological variations within zones, which are many and substantial; in fact, this has led to the introduction of a further sub-zonation by the same authors. Moreover, as with any categorization of physical reality, there are borderline areas, areas that have characteristics of more than one zone, of which the CL5Kwale area is an example.

All in all, agriculture in the two CL3 locations was characterized by a low to medium level of food crop production, a relatively high cash crop production (at least in comparison to the rest of the coast) and little livestock. The two CL4 locations were characterized by a medium to high level of food crop production, low to medium production of cash crops and a low level of livestock production. The CL5 area in Kwale had a substantial income from livestock but also relatively high food production, much higher than in Kilifi, a location in the heart of CL5. The latter area was characterized by low food crop and low cash crop production, with livestock as the main agricultural activity.

The agronomic situation in the various areas was further complicated by the fact that agro-ecological potential is one thing, but that the use of the land, i.e. the crops people actually choose to cultivate, is often quite another. An example is the cultivation of maize, a crop that is generally considered less suitable for the area by agricultural experts. Last, but not least, how and to what extent people wish to exploit their environment is highly dependent on alternative means of existence that are available, notably the opportunities for offfarm employment. This results in varying combinations of farm activities and wage labour in different areas and in individual households. The extent and nature of off-farm employment are discussed in the next section.

\subsection{Off-Farm Employment}

Off-farm employment includes all income-generating activities outside one's own farm and ranges from the processing and selling of self-produced foodstuffs (like roasted maize) to a regular job in the formal sector in town. The data below concern the formal as well as the informal sector, including figures on regular employment, temporary, casual and selfemployment.

\begin{tabular}{lcccccccc}
\hline Table 20 & Frequency of off-farm employment (o.f.e) & by research area \\
& Total & $\begin{array}{c}\text { Kwale } \\
\text { CL3 }\end{array}$ & $\begin{array}{c}\text { Kilifi } \\
\text { CL3 }\end{array}$ & $\begin{array}{c}\text { Kwale } \\
\text { CL4 }\end{array}$ & $\begin{array}{c}\text { Kilifi } \\
\text { CL4 }\end{array}$ & $\begin{array}{c}\text { Kwale } \\
\text { CL5 }\end{array}$ & $\begin{array}{c}\text { Kilifi } \\
\text { C55 }\end{array}$ \\
& & 69 & 60 & 64 & 44 & 48 & 120 \\
Number of people in o.f.e. & 405 & 69 & 1.2 & 1.3 & 0.9 & 1.0 & 2.4 \\
O.f.e.workers / h.hold (av.) & 1.4 & 1.4 & 1.2 & 42 & 21 & 27 & 33 \\
Adults in o.f.e. (\%) & 31 & 45 & 23 & 42 & 41 & 52 & 58 \\
Adult males in o.f.e. (\%) & 52 & 61 & 38 & 72 & 41 & \\
\hline
\end{tabular}


Overall, 31 per cent of the adult population was in some way or another engaged in offfarm employment (Table 20). The average number of people engaged in off-farm employment was 1.4 per household 22 Off-farm employment was particularly common in the CL3-Kwale, CL4-Kwale and CL5-Kilifi areas, earlier shown to have a low agricultural production. Off-farm employment was largely a male activity: 52 per cent of the adult men were employed, against only nine per cent of the women. Indeed, in the CL3 and CL4 areas in Kwale, 60-70 per cent of the men had some kind of employment; elsewhere this was less, but usualy still about 40-50 per cent. Most of the women who were employed came from the CL3-Kwale area. They made and sold craft products like mats and makutis, and prepared small food dishes for sale. This was the only area with a substantial number of female-headed households and Digo women generally tend to be less involved in agriculture than women from other groups while the local market in the area offers more opportunities than elsewhere. In the other areas, opportunities for women to earn income are mainly restricted to farm labour (Oosten 1989).

The employment opportunities in the rural locations are limited, and many workers had to travel to Mombasa or elsewhere to find employment (Table 21). This was the case for more than three-quarters of the workers. In the CL3-Kwale area, the large majority of workers managed to acquire work in the administrative location in which the research area is situated; this is largely because of the many tourist hotels in nearby Diani Beach and the spin-off employment this generates. Consequently, most of the workers in the latter area live at home full-time.

Workers in the other research areas usually live near the place of work, part-time or full-time. The percentage of workers with employment within the location corresponds closely with the number who are full-time residents, with one exception: CL4-Kwale. In this area, half the workers managed to live full-time at home but only a quarter was employed in the location. This means that the other quarter commuted daily to and from their work (mainly to Mombasa), which is possible because of the tarmac road connection and available transport facilities. The other areas have longer and often difficult connections with Mombasa, so that workers have to migrate to find employment. About half the workers were non-resident which means that they usually stay elsewhere, and can presumably

Table 21 Off-farm workers: place of work and residency by research area (\%)

\begin{tabular}{|c|c|c|c|c|c|c|c|c|}
\hline & & $\begin{array}{c}\text { Total } \\
(\mathrm{N}=405)\end{array}$ & $\begin{array}{c}\text { Kwale } \\
\text { CL3 (69) }\end{array}$ & $\begin{array}{c}\text { Kilifi } \\
\text { CL3 (60) }\end{array}$ & $\begin{array}{c}\text { Kwale } \\
\text { CL4 (64) }\end{array}$ & $\begin{array}{c}\text { Kilifi } \\
\text { CL4 (44) }\end{array}$ & $\begin{array}{l}\text { Kwale } \\
\text { CL5 (48) }\end{array}$ & $\begin{array}{c}\text { Kilifi } \\
\text { CL5 (120) }\end{array}$ \\
\hline orkplace: & $\begin{array}{l}\text { in location } \\
\text { in Mombasa } \\
\text { elsewhere }\end{array}$ & $\begin{array}{r}40 \\
41 \\
19 \\
100\end{array}$ & $\begin{array}{r}81 \\
14 \\
4 \\
100\end{array}$ & $\begin{array}{r}18 \\
50 \\
32 \\
100\end{array}$ & $\begin{array}{r}45 \\
34 \\
20 \\
100\end{array}$ & $\begin{array}{r}18 \\
46 \\
36 \\
100\end{array}$ & $\begin{array}{r}46 \\
40 \\
15 \\
100\end{array}$ & $\begin{array}{r}30 \\
55 \\
15 \\
100\end{array}$ \\
\hline sidency: & $\begin{array}{l}\text { full-time in h.hold } \\
\text { part-time } \\
\text { non-resident }\end{array}$ & $\begin{array}{r}45 \\
12 \\
43 \\
100\end{array}$ & $\begin{array}{r}83 \\
9 \\
9 \\
100\end{array}$ & $\begin{array}{r}23 \\
3 \\
73 \\
100\end{array}$ & $\begin{array}{r}67 \\
5 \\
28 \\
100\end{array}$ & $\begin{array}{r}18 \\
0 \\
82 \\
100\end{array}$ & $\begin{array}{r}42 \\
15 \\
44 \\
100\end{array}$ & $\begin{array}{r}34 \\
26 \\
40 \\
100\end{array}$ \\
\hline
\end{tabular}




\begin{tabular}{|c|c|c|c|c|c|c|c|}
\hline & $\begin{array}{c}\text { Total } \\
(\mathrm{N}=405)\end{array}$ & $\begin{array}{c}\text { Kwale } \\
\text { CL3 (69) }\end{array}$ & $\begin{array}{c}\text { Kilifi } \\
\text { CL3 (60) }\end{array}$ & $\begin{array}{c}\text { Kwale } \\
\text { CL4 (64) }\end{array}$ & $\begin{array}{c}\text { Kilifi } \\
\text { CL4 (44) }\end{array}$ & $\begin{array}{l}\text { Kwale } \\
\text { CL5 (48) }\end{array}$ & $\begin{array}{c}\text { Kilifi } \\
\text { CL5 (120) }\end{array}$ \\
\hline regular employment & 41 & 26 & 63 & 31 & 61 & 23 & 45 \\
\hline self-employment & 25 & 45 & 15 & 11 & 14 & 19 & 32 \\
\hline \multirow[t]{2}{*}{ temporary empl./casual labour } & 34 & 29 & 22 & 58 & 25 & 58 & 23 \\
\hline & 100 & 100 & 100 & 100 & 100 & 100 & 100 \\
\hline
\end{tabular}

send only a small portion of their salary home. This is different in the case of the part-time residents who come home regularly, and consequently contribute relatively more.

About half the off-farm workers were regularly employed (Table 22). These were people with a regular salary, which gives them a more secure basis of existence. The high percentages of regularly employed people in two of the Kilifi areas - CL3 and CL4 - are noteworthy. Although relatively few people in these areas were engaged in off-farm employment, the ones that were apparently had found regular jobs.

About 30 per cent of the workers were self-employed: shopkeepers, artisans, small traders, etc. Although this type of employment offered a more or less regular income, most of these people had only modest businesses. For instance, only 15 per cent of the selfemployed persons employed other people in turn.

Temporary employment and casual labour form comparable employment categories. Temporary employment concerned people who had work for a few months, but not permanently. Casual labourers were employed on a daily basis, technically they were hired anew each day and paid at the end of the same day. ${ }^{23}$ These kinds of employment had a lower remuneration than regular and self-employment and offered less security and less of a resource to assure food purchases in case food stocks being depleted.

The opportunities for regular employment are better with a higher level of education. For instance, three-quarters of the regularly employed had received some formal education, while this was the case for only half the group of self-employed/casual labourers. There is also a relation with place of work. Regular employment was usually found outside the location, in 80 per cent of the cases. The self-employed on the other hand usually had their place of work within the own location. Casual labour and temporary employment also tended to be found more often outside the location.

Type of employment strongly decides salary level. The estimated annual salary earned by casual labourers and temporarily employed was about sh.3,200, that of self-employed people about sh.9,200, and that of regular employed workers about sh.13,600. However, since many of the workers had to move and stayed more or less permanently near their place of work, there were costs involved and only part of the salary remained to be taken home. In other words, in estimating the contribution of off-farm workers to household income, one has to take into account the residency factor 24 The returns for wage labour, thus calculated, average slightly more than sh.5,100/worker 25 


\begin{tabular}{lcccccccc}
\hline Table 23 Household income from off-farm employment (o.f.e.) by research area \\
& Total & Kwale & Kilifi & Kwale & Kilifi & Kwale & Kilifi \\
& N=(297) & CL3 (50) & CL3 (50) & CL4 (48) & CL4 (50) & CL5 (49) & CL5 (50) \\
H.holds with o.f.e. income (\%) & 74 & 76 & 68 & 88 & 56 & 65 & 90 \\
O.f.e. income / hhold (sh/year) & 6931 & 8201 & 4273 & 7491 & 3555 & 3236 & 14779 \\
O.f.e. income / cu (sh/year) & 1261 & 1933 & 807 & 1821 & 661 & 731 & 1627 \\
\hline
\end{tabular}

Table 23 gives further information on the income from off-farm employment in the households, corrected for residency. In all, 74 per cent of the households had an income from off-farm employment. Almost half the off-farm income in these households was contributed by part-time and non-resident members of the household. For the total sample, the average income from off-farm employment was sh.6,930 per household which equals sh.1,260 per consumer unit. The differences between the areas are substantial, depending on the type of employment and residency of the worker. The highest incomes were found in two very disparate areas, CL3-Kwale and CL5-Kilifi. The lowest income figures are in the two areas with relatively high agricultural production and in CL3-Kilifi. These areas had low employment rates while most of the workers from these areas had to live elsewhere, with the associated costs, and consequently contributed smaller parts of their salaries to household income.

The relations between place of work, type of work, salary level and household income are as follows. In most areas there was little employment to be found, daily commuting was usually not possible, and people had to move to be near the place of work. Because of the living costs involved, this is only an option if the salary is sufficiently high, so that a sizeable balance remains to be taken home. Otherwise, people prefer to occupy themselves at home, particularly if there are possibilities at the farm to do so. In combination with the figures for agricultural returns per acre (Table 19) it is clear that in CL5-Kilifi the low agricultural returns more or less forced people into wage employment. On the other hand, in CL3-Kwale, returns for labour were higher and here it seemed that the existing employment opportunities pulled people away from agriculture. Oosten (1989) has also pointed at the relative neglect of agriculture in the CL3-Kwale area.

\subsection{Household Income}

The income composition for the households in the different research areas is given in Table 24. The average income was about sh.10,000 per household 26 or about sh.2,000 per consumer unit, which is close to an earlier estimate by the Rural Household Budget Survey of 1981-82 (CBS 1988) 27 Two-thirds of the income came from wage income, despite the fact that it was corrected for residency. Farm income contributed a third with cash crops 
Table 24 Household income by research area (sh/household/year)

\begin{tabular}{|c|c|c|c|c|c|c|c|}
\hline & $\begin{array}{c}\text { Total } \\
\mathrm{N}=(297)\end{array}$ & $\begin{array}{c}\text { Kwale } \\
\text { CL3 (50) }\end{array}$ & $\begin{array}{c}\text { Kilifi } \\
\text { CL3 (50) }\end{array}$ & $\begin{array}{c}\text { Kwale } \\
\text { CL4 (48) }\end{array}$ & $\begin{array}{c}\text { Kilifi } \\
\text { CL4 (50) }\end{array}$ & $\begin{array}{c}\text { Kwale } \\
\text { CL5 (49) }\end{array}$ & $\begin{array}{c}\text { Kilifi } \\
\text { CL5 (50) }\end{array}$ \\
\hline & 346 & 212 & 3449 & 22 & 4635 & 4385 & 3875 \\
\hline income & 693 & 820 & 42 & 74 & 3555 & 32 & $14779 *$ \\
\hline me, total & $=10396$ & $=10326$ & $=7722$ & $=9786$ & $=8190$ & $=7621$ & $=18653^{*}$ \\
\hline come/consumer uni & 1992 & 2576 & 1368 & 2390 & 1645 & 1871 & 2115 \\
\hline
\end{tabular}

* The high figures must be considered against the large household size in this area.

and livestock contributing only 13 per cent and the remaining 20 per cent consisting of the value of food crop production. Areas differ in economic activities and consequently the size of the resource base and its composition vary accordingly. The differences in farm income between the six areas range from an average of sh.2,125 to sh.4,635, that is by a factor two. The differences in employment income vary even more from sh.2,734 to sh.8,120, or by a factor 3. When agricultural incomes are relatively high, wage incomes tend to be low and where wage incomes are high, agricultural income tends to be low (with the exception of the CL5-Kilifi area where the large household size plays a distorting role).

Table 25 gives the results for household income and income composition aggregated by agro-ecological zone and also presents the percentage of households with incomes below sh.1,000, the income level that can be considered the Food Poverty Line, below which families do not have sufficient income to assure the minimal energy requirements of the household members ${ }^{28}$ It is clear that there are no systematic differences between agroecological zones; particularly when income is expressed per consumer unit the estimates are near equal and there are little or no differences in respect of the number of households below the food poverty line. Nevertheless, the results indicate that no less than 37 per cent of the households were living in dire poverty; a figure that is very similar to an earlier estimation of 41 per cent by Greer \& Thorbecke (1986).

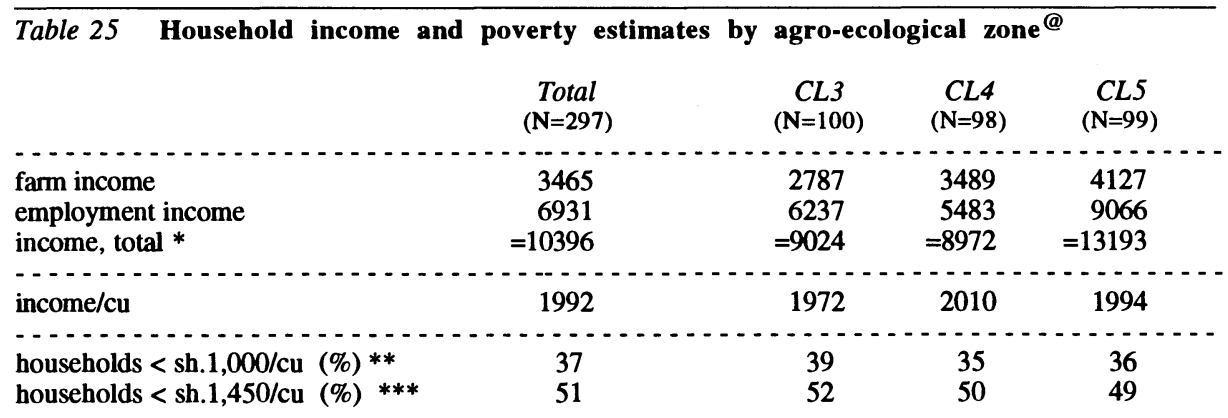

\footnotetext{
@ CL3=coconut-cassava; CL4=cashewnut-cassava; CL5=livestock-millet zone

$*$ sh/household/year $\quad * *$ food poverty line $* * *$ minimum existence level
} 
Households with such low income levels will not be able to spend all income on food; other household expenses are also necessary. Available data indicate that poor rural households spend about 30 per cent of their income on non-food expenses (CBS 1988). If allowance is made for this, an income level of sh.1,450/cu can be regarded as minimum existence level. In that case, about half the households can be considered as living in poverty and who can be expected to have regular difficulties in coping with daily food provision.

\section{Income class and income composition}

There were great variations in income between households. The lowest quartile had incomes below sh.500/cu, while the upper quartile earned more than six times as much, namely sh. $3,000 / \mathrm{cu}$ and more. Table 26 shows the income composition for four income classes and confirms the importance of wage income in deciding household means of existence. The higher the income group the greater the contribution from wage income, i.e. higher incomes were realized through wage employment.

The low income groups consist of households that had to depend mostly on farm activities, food crop cultivation in particular, and that appeared to be unable to meet household needs in this way. The middle income groups were better able to meet household needs, but farm incomes, on average, remained below sh.1,000/cu. It is evidently very difficult, if not impossible, to rely fully on farming to meet household needs under the prevailing conditions in the districts. 29

\begin{tabular}{|c|c|c|c|c|c|c|c|c|c|c|}
\hline \multirow{2}{*}{ Table 26} & All & & $I C$ & & $I C$ & & \multicolumn{2}{|c|}{ IC3 } & \multicolumn{2}{|l|}{ IC4 } \\
\hline & $\mathrm{sh} / \mathrm{cu}$ & $\%$ & $\mathrm{sh} / \mathrm{cu}$ & $\%$ & $\mathrm{sh} / \mathrm{cu}$ & $\%$ & $\mathrm{sh} / \mathrm{cu}$ & $\%$ & $\mathrm{sh} / \mathrm{cu}$ & $\%$ \\
\hline food crops & 486 & 24 & 299 & 58 & 545 & 39 & 448 & 18 & 763 & 16 \\
\hline cash crops and livestock & 245 & 12 & 63 & 12 & 175 & 12 & 298 & 12 & 587 & 12 \\
\hline employment & 1261 & 63 & 152 & 30 & 689 & 49 & 1772 & 70 & 3372 & 71 \\
\hline total & $=1992$ & 100 & $=514$ & 100 & $=1408$ & 100 & $=2517$ & 100 & $=4721$ & 100 \\
\hline
\end{tabular}

@ IC1=<1000sh/cu (N=109); IC2=1000-1999 (N=73); IC3=2000-2999 (N=50); IC4>=3000sh/cu (N=65)

\subsection{Conclusion}

Wage income contributed 65 per cent to the total income, the value of food crops accounted for 20 per cent, cash crops and livestock for the remaining 15 per cent. Compared with the earlier CBS estimates, there was no increase in income; more than 40 per cent of the rural population lived in dire poverty. In areas with low agricultural returns people were more or less forced into wage employment; in other areas where employment opportunities existed nearby, it appeared that many people were drawn away from agriculture. The low returns from agriculture mean that households dependent on agriculture are at risk. In fact, only 20 
per cent of the rural population managed to realize an income from agriculture above the Food Poverty Line. Off-farm employment was the major source of income.

There is little or no difference in household income between households in different agro-ecological zones despite the differences in agricultural potential. The number of poor households in the three zones studied was virtually the same (40\%). The similar distribution does not mean that the agricultural and economic activities in the zones were the same; obviously they were not. Rather, it means that in each of the zones a similar number of households fail to rise above the Poverty Line. Among the households that manage to do so, wage income was the major component, and since employment opportunities are not location-bound the similarity is not surprising. What is surprising, however, is that in each zone so few households managed to live off farming only.

At the same time there are large individual differences in the way people choose to realize their available resources. Areas in the same agro-ecological zone differed considerably. There are even greater differences in household income and income composition between households within the same area. This income differentiation between households is mainly due to differences in income from employment, with the income levels from the top and bottom income classes differing more than sixfold. 


\section{Household Food Consumption *}

\subsection{Food Habits}

In most households, three meals are served. Breakfast is prepared early in the morning before the children leave for school. The second meal is prepared between twelve and two o'clock, while dinner is taken in the evening, usually at about seven o'clock. Some households may skip lunch or breakfast - or sometimes both when no food is available - but dinner is the most important meal of the day. It is also the meal in which all resident household members partake. Some members may leave early in the morning for work, before breakfast, often skipping lunch as well. Others may only miss lunch. Most of those who, for various reasons, were absent during the day usually returned before dinner.

Breakfast in many households consists of some leftovers from the previous evening. These leftovers, heated up or eaten cold, are usually accompanied by some tea with sugar (and/or milk). Other households may prepare special foods for breakfast, such as chapatis (unleavened bread), a loaf of bread or uji (thin cereal porridge, usually from maize flour). Lunch and dinner generally consist either of ugali (stiff maize porridge) taken with a rel-

* This chapter is a revised version of text in Niemeijer, Foeken \& Klaver (1991, 24-36; 48-52; 58-67) 
ish, or of a dish prepared with boiled roots, mostly cassava. This latter type of dish is more commonly taken at lunch time when the cassava is carried home from the field for that purpose. Side dishes are mainly different types of cooked green vegetables, but other kinds are prepared from legumes, unripe mangoes, fish, meat, or chicken, or simply consist of sour milk. If nothing else is available, some households may take ugali with just a little salted water. The ugali is eaten from a big plate or bowl, shared by a number of people who break off lumps of porridge and dip them in the relish to increase its palatability.

This general pattern, which nowadays is common in many parts of Kenya, does not do justice to the great variety in the coastal food culture. In the coastal strip, dishes are generally more varied and contain more ingredients - like fish (fresh or dried) and coconut - which is due to the influence of the Swahili tradition on the local kitchen. This is particularly true for the Digo in Kwale District. Compared with the other coastal communities, they use more spices, and consume, beside the basic dishes mentioned above, a larger variety of snacks, such as chapatis and various types of fritters, and special dishes, such as pilau (spiced rice) and sweetened vermicelli. Furthermore, in CL3Kwale, the only Digo research area, a lot of food-peddling takes place, which is rather uncommon in the other five research areas. Especially during the month of Ramadar 30 , when people fast during day-time hours and eat during the evening and night, many peddlers and stalls open up during the evening hours.

Food preparation is a duty shared among the married women of the household although they may leave the actual task of preparation to some of the younger unmarried women, who carry out their duty under their mothers' supervision. If no women are present, cooking will be done by one of the boys. Married women often take turns in supervision or preparation, giving them greater freedom of movement on days that the other women are preparing the meals.

When the food is prepared it is shared out between the household members. The men usually eat together, the women may take their meal together in some households, but they often eat on their own with their children. In the latter case the women will prepare food separately and each woman will send some of her food to the men, who will sample from all food prepared in the household.

In households with young children, special weaning foods may be prepared in addition to the main household dishes. Sometimes this is just a portion of ugali which is diluted with a little milk or reconstituted milk powder. Uji, however, is the most important weaning food. The mother usually handfeeds the very small child, at a later age the child will drink from a cup. If $u j i$ is prepared in the household, the older children and adults present may also receive a share. There is no clear distinction between weaning food and adult food in this respect. At the end of the weaning period, that is from about two years onwards, the young child often eats with the father, who is usually served first. The father will feed the child small morsels of food while taking his own meal. When the father is not present, another adult or one of the older children may be given this responsibility. 
Afterwards, the child may still join the other children who are fed in a group, sharing a dish together. When the next born comes of age, however, the special position with the father has to be relinquished and the child will have to get its share from the common dish in competition with the other children.

\subsection{Energy and Protein Intake 31}

\section{Intake levels and composition}

The average energy intake - measured in kilocalories per consumer unit per day - is slightly less than $2600 \mathrm{kcal}$. This is comparable to the energy intake reported for groups of peasant smallholders elsewhere in Kenya 32 With energy requirements at 2960 $\mathrm{kcal} /$ day per consumer uni 33 , the energy intake in each of the five survey rounds was, on average, 6-17 per cent below the reference value (Table 27). In about one-third of the house holds the average energy intake was equal to or above the reference value (instead of 50\% expected theoretically when average requirements are met). In no less than onequarter of the households the average energy intake during the day of study appeared to be less than 60 per cent of the requirements, i.e. less than $1776 \mathrm{kcal} .34$

During most of the year the energy intake was around a base level of $2500 \mathrm{kcal} / \mathrm{cu}$ and there is no pronounced dip at any time of the year. On the contrary, a peak in energy intake was found in May-June with $2780 \mathrm{kcal} / \mathrm{cu}$ and a second, lower peak occurred in November-December, that is during the period of the long rains and the short rains respectively. It is noteworthy that there is no increased energy intake in the immediate postharvest months (September-October) when stocks are plentiful. The peak in May-June occurs because of a higher intake of roots (cassava) and legumes (cowpeas). In the period February-March, at the end of the dry season, the consumption of vegetables and legumes is low (Table 28).

\begin{tabular}{|c|c|c|c|c|c|c|c|}
\hline \multicolumn{8}{|c|}{ Table $27 \quad$ Energy intake by survey round } \\
\hline & & $\begin{array}{l}\text { all } \\
\text { rounds }\end{array}$ & $\begin{array}{c}j u V \\
\operatorname{aug}^{\prime} 85 \\
(\mathrm{~N}=283)\end{array}$ & $\begin{array}{c}\text { nov/ } \\
\text { dec'85 }^{\prime} \\
(278)\end{array}$ & $\begin{array}{c}f e b / \\
\text { mar'86 } \\
(272)\end{array}$ & $\begin{array}{c}\text { may/ } \\
\text { jun'86 } \\
(269)\end{array}$ & $\begin{array}{l}\text { sep/ } \\
\text { oct'86 } \\
(266)^{*}\end{array}$ \\
\hline AVERAGE & $\begin{array}{l}\mathrm{kcal} / \text { day/cons.unit } \\
\text { (s.d.) }\end{array}$ & $\begin{array}{r}2578 \\
(1203)\end{array}$ & $\begin{array}{r}2511 \\
(1120)\end{array}$ & $\begin{array}{r}2632 \\
(1323)\end{array}$ & $\begin{array}{r}2507 \\
(1127)\end{array}$ & $\begin{array}{r}2780 \\
(1308)\end{array}$ & $\begin{array}{r}2458 \\
(1135)\end{array}$ \\
\hline $\begin{array}{l}\text { HOUSEHOLD } \\
\text { DISTRIBUTION } \\
(\%)\end{array}$ & $\begin{array}{l}>100 \% \text { requirements** } \\
60-99 \% \text { requirements } \\
<60 \% \text { requirements }\end{array}$ & $\begin{array}{r}31 \\
43 \\
26 \\
100\end{array}$ & $\begin{array}{r}29 \\
46 \\
25 \\
100\end{array}$ & $\begin{array}{r}32 \\
41 \\
27 \\
100\end{array}$ & $\begin{array}{r}29 \\
42 \\
29 \\
100\end{array}$ & $\begin{array}{r}37 \\
41 \\
23 \\
100\end{array}$ & $\begin{array}{r}28 \\
44 \\
28 \\
100\end{array}$ \\
\hline
\end{tabular}

\footnotetext{
* The $\mathrm{N}$-figures also apply to Tables 28-33.

** Energy requirements are estimated at $2960 \mathrm{kcal} /$ day per consumer unit.
} 
Table 28 Energy intake by food group and survey round (kcal/day/consumer unit)

\begin{tabular}{lrrrrrr} 
& $\begin{array}{c}\text { all } \\
\text { rounds }\end{array}$ & $\begin{array}{c}\text { jul } \\
\text { aug'85 }\end{array}$ & $\begin{array}{c}\text { nov/ } \\
\text { dec'85 }\end{array}$ & $\begin{array}{c}\text { feb/ } \\
\text { mar'86 }\end{array}$ & $\begin{array}{r}\text { may/ } \\
\text { jun'86 }\end{array}$ & $\begin{array}{c}\text { sep/ } \\
\text { oct'86 }\end{array}$ \\
cereals & 1910 & 1948 & 1940 & 1956 & 1872 & 1836 \\
legumes & 112 & 52 & 97 & 74 & 180 & 155 \\
roots, tubers \& starchy staples & 144 & 113 & 125 & 138 & 257 & 89 \\
vegetables & 34 & 52 & 41 & 13 & 43 & 22 \\
fruits & 16 & 2 & 22 & 10 & 34 & 13 \\
animal products & 138 & 111 & 159 & 154 & 132 & 132 \\
fats & 39 & 49 & 68 & 17 & 40 & 21 \\
oil seeds \& nuts & 81 & 75 & 67 & 65 & 112 & 86 \\
miscellaneous & 103 & 108 & 113 & 81 & 110 & 103 \\
$\quad$ total & $=2578$ & $=2511$ & $=2632$ & $=2507$ & $=2780$ & $=2458$ \\
\hline
\end{tabular}

In the literature reviewed earlier, a close relation is generally postulated between rainfall, food consumption and labour in such a way that the fluctuations in food consumption and labour reinforce each other (Ferro-Luzzi, Pastore \& Sette 1987). Food consumption is expected to be low during the rainy season (because stored food from last year's harvest is finished) but at the same time there is a labour peak (land preparation, seeding, planting, and weeding) while harvesting usually takes place at the onset of the subsequent dry season; hence increased food energy requirements during this time of the year. The two effects reinforce each other and result in a strong negative energy balance.

In the coastal areas of Kenya, this relationship appears to be different. The long rainy season roughly starts in March and ends in June, but April and May are the months with the real rainfall peak. Food intake is indeed relatively low at the beginning of the long rains (March), when land preparation and seeding of maize are being done. The peak of the rainy season (April-May) coincides with the peak in labour requirements, as weeding is the most intensive (both in hours and in effort) type of labour that has to be done. It appears that energy intake is highest during this period. In the following two months energy intake is relatively low again. This is the period when maize and beans are harvested. Finally, the period from September to January is, in terms of agricultural labour, a relatively easy period, except for those farmers who try to realize a second harvest which is reflected in a concurrent minor peak of energy intake in November-December.

Table 29 Contribution of macro-nutrients to energy intake by survey round $(\mathrm{kcal} / \mathrm{cu})$

\begin{tabular}{|c|c|c|c|c|c|c|c|c|c|c|c|}
\hline & $\begin{array}{c}\text { all } \\
\text { rounds }\end{array}$ & \multicolumn{2}{|c|}{$\underset{\text { aug'85 }}{j u V}$} & \multicolumn{2}{|c|}{$\begin{array}{c}\text { nov/ } \\
\text { dec'85 }^{\prime}\end{array}$} & \multicolumn{2}{|c|}{$\begin{array}{l}\text { feb } \\
\text { mar'86 }\end{array}$} & \multicolumn{2}{|c|}{$\underset{\text { jun'86 }}{\operatorname{may/}}$} & \multicolumn{2}{|c|}{$\begin{array}{c}\text { sep/ } \\
\text { oct'86 }\end{array}$} \\
\hline & mean $\%$ & mean & $\%$ & mean & $\%$ & mean & $\%$ & mean & $\%$ & mean & $\%$ \\
\hline carbohydrates & $1974 \quad 77$ & 1918 & 76 & 1983 & 75 & 1948 & 78 & 2163 & 78 & 1859 & 76 \\
\hline fats & $316 \quad 12$ & 318 & 13 & 357 & 14 & 274 & 11 & 318 & 11 & 312 & 13 \\
\hline proteins & $288 \quad 11$ & 275 & 11 & 292 & 11 & 285 & 11 & 299 & 11 & 287 & 12 \\
\hline total & $=2578 \quad 100$ & $=2511$ & 100 & $=2632$ & 100 & $=2507$ & 100 & $=2780$ & 100 & $=2458$ & 100 \\
\hline
\end{tabular}


Table 30 Protein intake by survey round

\begin{tabular}{|c|c|c|c|c|c|c|c|}
\hline & & $\begin{array}{l}\text { all } \\
\text { rounds }\end{array}$ & $\underset{\text { aug'85 }}{j u V}$ & $\begin{array}{c}\text { nov/ } \\
\text { dec' } 85^{\prime}\end{array}$ & $\begin{array}{l}f e b / \\
\text { mar'86 }\end{array}$ & $\begin{array}{c}\text { may/ } \\
\text { jun'86 }\end{array}$ & $\begin{array}{l}\text { sep/ } \\
\text { oct'86 }\end{array}$ \\
\hline AVERAGE & $\begin{array}{l}\text { grams/day/cons.unit } \\
\text { (s.d.) }\end{array}$ & $\begin{array}{r}72 \\
(42)\end{array}$ & $\begin{array}{r}69 \\
(36)\end{array}$ & $\begin{array}{r}73 \\
(43)\end{array}$ & $\begin{array}{r}71 \\
(47)\end{array}$ & $\begin{array}{r}75 \\
(44)\end{array}$ & $\begin{array}{r}72 \\
(41)\end{array}$ \\
\hline $\begin{array}{l}\text { HOUSEHOLD } \\
\text { DISTRIBUTION } \\
(\%)\end{array}$ & $\begin{array}{l}>100 \% \text { requirements* } \\
60-99 \% \text { requirements } \\
<60 \% \text { requirements }\end{array}$ & $\begin{array}{r}68 \\
22 \\
11 \\
100\end{array}$ & $\begin{array}{r}69 \\
21 \\
10 \\
100\end{array}$ & $\begin{array}{r}67 \\
21 \\
12 \\
100\end{array}$ & $\begin{array}{r}68 \\
21 \\
11 \\
100\end{array}$ & $\begin{array}{r}70 \\
19 \\
12 \\
100\end{array}$ & $\begin{array}{r}65 \\
26 \\
9 \\
100\end{array}$ \\
\hline
\end{tabular}

* A safe level of protein intake was estimated at $50 \mathrm{grams} /$ day per consumer unit (WHO/FAO 1985).

The contribution of carbohydrates, fats and proteins to the total energy intake is presented in Table 29. Although the absolute figures show fluctuations as described above, the relative contributions are constant throughout the year, especially for protein and carbohydrates. Fats contribute about 12 per cent, which, although within the 5-35 per cent range that is considered to be not incompatible with health, is a fairly low percentage, resulting in a low energy density of the diet.

The results in respect of intake of protein are presented in Table 30. It ranges from a minimum level of 69 grams/day per consumer unit in July-August to 75 grams/day in May-June. Although the protein intake tends to follow total food (i.e. energy) intake, the fluctuations are less. This can be attributed to a compensatory trend between the main sources of protein; in particular in May-June the lower contribution of cereals and foods of animal origin is compensated by the higher intake of legumes. Thus, overall protein intake shows no substantial fluctuations. In each survey round about one-third of the households had an average protein intake below the recommended level, while in onetenth of the households average protein intake was less than 60 per cent of that level. Although the levels of protein intake are more favourable than the levels of energy intake, if energy is lacking in the diet, proteins will be more readily used for energy purposes than for the metabolic functions to which the requirements refer.

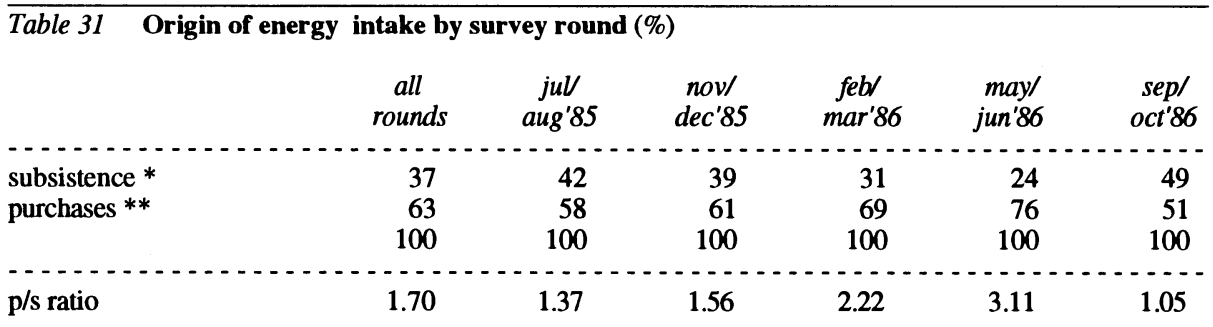

* contribution of home-produced foods to energy intake.

** contribution of purchased food to energy intake (also includes gifts of food which are negligible). 


\section{Origin of energy and protein intake}

Further specification shows the part of the energy intake that is contributed by subsistence foods and the part that is purchased together with the ratio of purchased over subsistence energy (Table 31). The ratio is always more than one, showing that at all times the largest part of energy intake comes from purchased foods, not subsistence foods. Through the year, subsistence foods (also referred to as home-production and home stocks) contribute only about 37 per cent of the energy intake but a clear seasonal pattern is visible 36 The consumption of energy from subsistence crops is highest (almost 50\%) in September-October, the period shortly after the harvest of the long rains, so that cereals and many vegetables, legumes and fruits are available. After that, the contribution of home-produced food falls steadily to a minimum of 20-25 per cent in May-June. This is also the period with the highest energy intake, however, which means that most food is bought and the ratio of purchased/subsistence energy reaches 3.1. The pattern for protein intake is not different.

The contribution of subsistence crops differs for different food groups (Figure 6). As regards cereals, the main staple food, the figure makes clear that this food group is by far the most important source of energy, but also that most of it (70\%) is purchased, confirming that this is a food-deficit region. The intake from roots, tubers and starchy staples (mainly cassava), vegetables (mainly green leaves), fruits (mainly mangoes), and oil seeds and nuts (coconuts) largely came from home production. Legumes and animal products were largely purchased. Finally, fats and the various items under the category miscellaneous( mainly soda's, syrups, sugar) are nearly always bought.

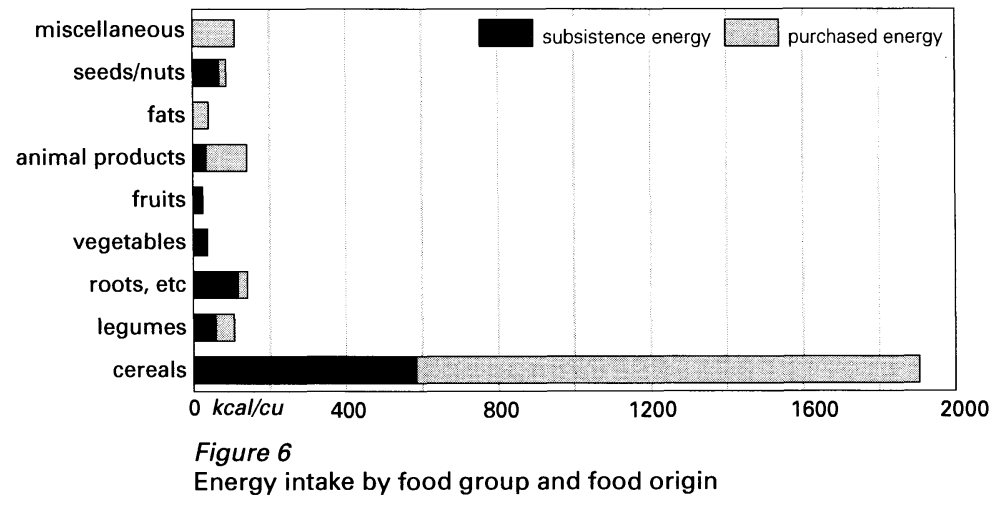

\subsection{Seasonal Variation in Energy Intake}

Table 32 gives the seasonal fluctuations of energy intake from subsistence crops with a breakdown by food group. Cereal intake has a strong unimodal pattern of fluctuation: it is 
highest during and immediately after the long rains harvest (July-December: 650-800 $\mathrm{kcal} / \mathrm{cu}$ ) and lowest during the period preceding the harvest (May-June: about $160 \mathrm{kcal} /$ cu). The second largest food group as a source of home-produced energy — roots, tubers and starchy fruits - has a unimodal pattern as well. It shows a maximum during the long rains (May-June: $190 \mathrm{kcal} / \mathrm{cu}$ ), the period in which most of last year's cassava is harvested and the new crop is planted. It partly complements the dip in cereals consumption. Legumes, third in importance, show a less clear pattern. Legumes are harvested fresh during the long rains (May-June) and the short rains (November-December), but only the long rains of 1986 produced a sizeable harvest. Oil seeds and nuts provide a small but stable source of home-produced energy, with little seasonal fluctuation.

During the long rains the consumption of home-produced maize is about $630 \mathrm{kcal} / \mathrm{cu}$ lower than during the post-harvest season. The cultivation of cassava, as the second major supplier of subsistence energy, plays a role as a preventive coping mechanism in those areas that allow its cultivation. The energy intake from home-produced roots, tubers, and starchy fruits (Table 32) increases when energy from home-produced cereals diminishes, although not enough to fill the gap. At its peak, energy intake from subsistence roots and tubers accounts for almost $200 \mathrm{kcal} / \mathrm{cu}$, which is low compared to actual requirements. As a result, the unimodal seasonality of total home-produced energy is somewhat less pronounced than that of home-produced cereals alone, but comparing the situation in MayJune with that of the post-harvest period, the difference is still $470 \mathrm{kcal} / \mathrm{cu}$.

Food purchases, however, were the main mechanism to reduce the effects of the largely unimodal cycle of cereal production (Table 33) 37 Food purchases were highest in May-June, during the long rains, not only compensating for the drop in home-produced energy of about $400 \mathrm{kcal}$ but also enabling the increase in total intake of about 300 $\mathrm{kcal} / \mathrm{cu}$ during the rainy season. The food purchases at this time consist of cereals (mostly maize flour) but also of legumes and a mixed group that includes animal products and nuts. Apparently during this peak period people do have the means to purchase food despite low incomes; but not only that: the food is also available in the duka's (small dry good stores).

Table 32 Energy intake (subsistence) by survey round and food group (kcal/day/consumer unit)

\begin{tabular}{lcccrrr} 
& $\begin{array}{c}\text { all } \\
\text { rounds }\end{array}$ & $\begin{array}{c}\text { juV } \\
\text { aug'85 }\end{array}$ & $\begin{array}{c}\text { nov/ } \\
\text { dec'85 }\end{array}$ & $\begin{array}{c}\text { feb } \\
\text { mar'86 }\end{array}$ & $\begin{array}{r}\text { may/ } \\
\text { jun'86 }\end{array}$ & $\begin{array}{c}\text { sep/ } \\
\text { oct'86 }\end{array}$ \\
cereals & 578 & 811 & 659 & 469 & 162 & 790 \\
legumes & 55 & 19 & 55 & 19 & 86 & 96 \\
roots, tubers etc. & 116 & 82 & 108 & 114 & 190 & 85 \\
vegetables \& fruits & 44 & 48 & 51 & 19 & 74 & 30 \\
animal, fats, seeds, nuts & 85 & 70 & 78 & 89 & 102 & 85 \\
other & 1 & 0 & 1 & 0 & 1 & 1 \\
$\quad$ total & $=1030$ & $=953$ & $=710$ & $=616$ & $=1087$ \\
\hline
\end{tabular}


Table 33 Energy intake (purchases) by survey round and food group (kcal/day/consumer unit)

\begin{tabular}{|c|c|c|c|c|c|c|}
\hline & $\begin{array}{l}\text { all } \\
\text { rounds }\end{array}$ & $\underset{\text { aug'85 }}{j u V}$ & $\begin{array}{c}\text { nov/ } \\
\text { dec' } 85^{2}\end{array}$ & $\underset{\text { mar'86 }}{\mathrm{feb}}$ & $\underset{\text { jun'86 }}{\operatorname{may/}}$ & $\begin{array}{c}\text { sep/ } \\
\text { oct'86 }\end{array}$ \\
\hline cereals & 1332 & 1137 & 1281 & 1486 & 1709 & 1046 \\
\hline legumes & 56 & 33 & 42 & 55 & 94 & 59 \\
\hline roots, tubers etc & 29 & 32 & 17 & 23 & 66 & 5 \\
\hline vegetables \& fruits & 6 & 7 & 12 & 4 & 4 & 6 \\
\hline animal, fats, oil seeds \& nuts & 173 & 165 & 216 & 147 & 182 & 155 \\
\hline other & 102 & 108 & 112 & 81 & 108 & 102 \\
\hline total & $=1698$ & $=1481$ & $=1679$ & $=1797$ & $=2163$ & $=1372$ \\
\hline
\end{tabular}

\section{Research areas}

There exist considerable differences between the research areas (Table 34). The three areas in Kwale and one in Kilifi (CL5) have an energy intake above the overall average: CL4 in Kwale having the highest energy intake $(2850 \mathrm{kcal} / \mathrm{cu}) 38$ In the remaining two areas in Kilifi (CL3/CL4) it is less than $2400 \mathrm{kcal}$ or about $600 \mathrm{kcal}$ below the required level. It was already mentioned that less than half of the total energy intake is contributed by subsistence crops but in this respect the areas also differ considerably. Consumption of subsistence food is highest in CL5-Kwale and CL4-Kilifi which agrees with the fact that these are the two areas with the highest degree of food self-sufficiency (p. 57). Similarly, the consumption of home-produced food is low in the areas with low food self-sufficiency such as CL3-Kwale and CL5-Kilifi and reflected in the high p/s ratio 39

Table 35 gives the results for energy intake in the respective areas at different times of the year. For all areas combined the average intake varies from $2458 \mathrm{kcal}$ to $2780 \mathrm{kcal}$ in different rounds, a range of $322 \mathrm{kcal}$. Seasonal fluctuations in energy intake can be quantified in various ways. The table firstly lists the range: the maximum difference between rounds. Secondly, the average (absolute) deviation per round from the mean energy intake over all rounds is given and this parameter will be used below in Chapters 5 and 6 for purposes of analysis 40

The maximum difference between rounds varies from $400 \mathrm{kcal}$ in one area to $800 \mathrm{kcal}$ in another. The average deviation varies from $130 \mathrm{kcal}$ to $230 \mathrm{kcal}$ for different areas.

Table 34 Energy intake by research area and food origin ( $\mathrm{kcal} / \mathrm{cu}$; all rounds combined) @

\begin{tabular}{|c|c|c|c|c|c|c|c|}
\hline & All areas & CL3-Kwale & CL3-Kilifi & CLA-Kwale & CLA-Kilifi & CLS-Kwale & CLS-Kilifi \\
\hline & kcal \% & kcal \% & kcal \% & kcal \% & kcal \% & kcal \% & kcal \% \\
\hline $\begin{array}{l}\text { subsistence } \\
\text { purchased } \\
\text { total }\end{array}$ & $\begin{array}{rr}879 & 34 \\
1698 & 66 \\
2578 & 100\end{array}$ & $\begin{array}{rr}436 & 17 \\
2176 & 83 \\
2612 & 100\end{array}$ & $\begin{array}{rr}822 & 34 \\
1572 & 66 \\
2394 & 100\end{array}$ & $\begin{array}{rr}751 & 26 \\
2110 & 74 \\
2862 & 100\end{array}$ & $\begin{array}{lr}1121 & 48 \\
1205 & 52 \\
2326 & 100\end{array}$ & $\begin{array}{rr}1542 & 58 \\
1116 & 42 \\
2658 & 100\end{array}$ & $\begin{array}{rr}629 & 24 \\
2023 & 76 \\
2652 & 100\end{array}$ \\
\hline p/s ratio & 1.70 & 4.86 & 1.69 & 2.43 & 0.85 & 0.63 & 3.15 \\
\hline
\end{tabular}

@ Detailed results in Appendix 7-8 (p. 113). 


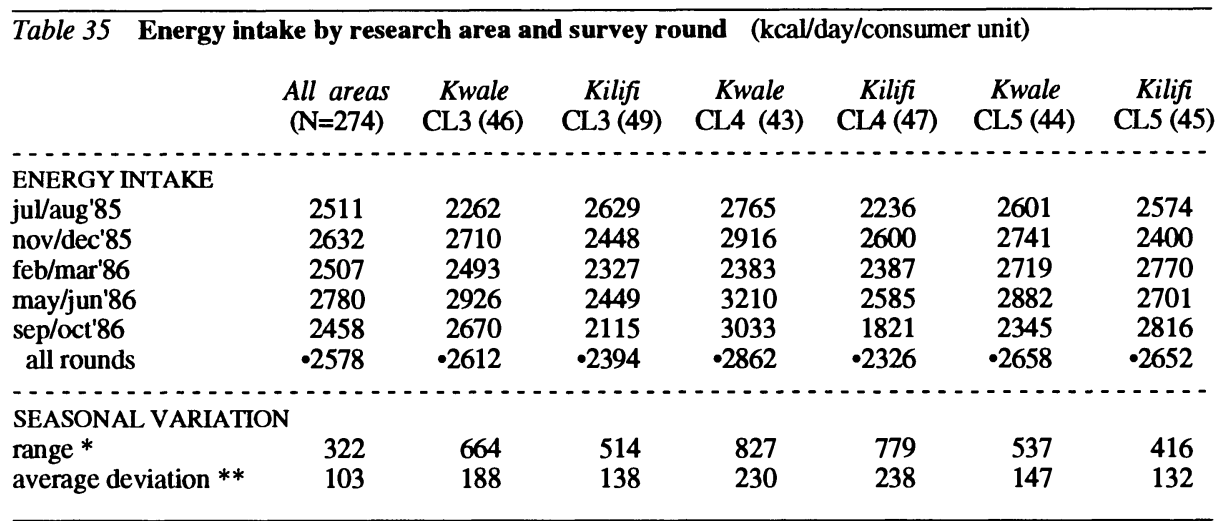

\footnotetext{
* Maximum difference between rounds.

** Average (absolute) deviation from the mean over five rounds.
}

The seasonal variation that occurs in the CL4 areas is greater than in the other areas, while the least variation occurs in the CL5 areas and CL3-Kilifi. The average deviation for all areas combined is $100 \mathrm{kcal}$, which is less than that for the individual research areas. This is because the seasonal fluctuations in different areas do not occur simultaneously, but differ in respect of the time of the year at which upward or downward swings occur so that the overall pattern will be attenuated. More insight is gained when the results for subsistence energy and purchased energy are analyzed separately.

The average deviation over five rounds for energy from different origins is listed in Table 36. For energy from subsistence origin the lowest deviation occurs in CL3-Kwale which is the area with the lowest intake of energy from subsistence origin. The greatest deviation is $509 \mathrm{kcal}$ in CL5-Kwale. For energy from purchased origin it is even higher, namely $644 \mathrm{kcal}$ in CL4-Kilifi. Since the variations in total energy (Table 35) are considerably smaller, this means that the variations in subsistence energy and purchased energy compensate each other. This is understandable from the nature of food consumption: households try to match total intakes to human requirements, which vary much less than food supply. If the two were to compensate each other perfectly their respective seasonal variation would be identical and no variation would occur in total energy intake. This, however, is not the case; which means that patterns in home energy and purchased energy do not cancel each other out completely. Still, across areas, the variations largely act in concert.

Generally, when the variation in home energy is high, the variation in purchased energy is also high and vice versa. The variation in purchased energy is greater than that in home energy (with the exception of two areas), which is understandable in view of the earlier noted peak in total intake in May/June. Food purchases not only compensate for the lesser subsistence energy availabe at that time of the year but also make an increase in intake possible. 
Table $36 \quad$ Variations in energy intake by research area and food origin @ (kcal/day/consumer unit; average absolute deviation from the mean over five rounds)

$\begin{array}{lccccccc} & \text { All } & \text { Kwale } & \text { Kilifi } & \text { Kwale } & \text { Kilifi } & \text { Kwale } & \text { Kilifi } \\ \text { subsistence origin } & 173 & 112 & 152 & 142 & 484 & 509 & 344 \\ \text { purchased origin } & 225 & 109 & 241 & 285 & 644 & 602 & 240\end{array}$

@ Detailed results by area and survey round on which the table is based are listed in Appendix 7-8 (p. 113).

Seasonal variation in total intake in this case is driven by seasonal variations in energy intake from subsistence origin. The variation in subsistence energy will be higher in areas where intake of subsistence energy is high, as in the case of CL4-Kilifi and CL5Kwale, the areas with the highest degree of food self-sufficiency. In the first three areas - CL3-Kwale, CL3-Kilifi and CL4-Kwale - the seasonal variations in subsistence energy are lessened by higher cassava consumption during May-June. 41 In CL5-Kilifi, where intake of subsistence energy is relatively low, the variation in subsistence energy is nevertheless high because no compensation by increased cassava consumption occurs. The variations in energy intake from purchased origin generally show the same pattern as subsistence energy, and are generally somewhat higher because of the peak in purchases in May/June.

\section{Agro-ecological zones}

The level of energy intake differs remarkably little between the three agro-ecological zones (Table 37). If any differences exist, they favour the households in the agro-ecological zones with the lesser agricultural potential. When results are broken down by food origin greater differences emerge. The energy intake from subsistence production differs by about $450 \mathrm{kcal}$ between CL3 and CL5. The figure is highest in the CL5 zone, which is mostly due to the results in the CL5-Kwale area. Similarly, the energy from purchased origin also shows considerable differences between zones, but this time in the other direction: $300 \mathrm{kcal}$ greater in the CL3 zone and compensating the lower intake from subsistence energy here.

In all zones energy intake is highest in May-June, but the peak tends to be higher in the CL4 and CL5 zones, where most agricultural cultivation is going on at this time of the year. It is also true that the energy intake from subsistence origin at this time of the year is lowest in these two zones, conforming to the 'classical' seasonality scenario. The consumption of energy of purchased origin is the greatest at this time of the year. The households in the CL3 zone, however, show a relatively flat pattern in which the seasonal variation in subsistence energy and purchased energy are low, particularly in CL3-Kwale as was already mentioned. The variation in total energy intake is also low in the CL5 zone, but in this zone the variations in subsistence energy and purchased energy are 


\begin{tabular}{|c|c|c|c|c|c|c|c|c|c|}
\hline \multirow[t]{3}{*}{ Table 37} & \multicolumn{9}{|c|}{ agro-ecological zone $(\mathrm{kcal} / \mathrm{day} / \mathrm{cu}) @$} \\
\hline & \multicolumn{3}{|c|}{ TOTAL ENERGY } & \multicolumn{3}{|c|}{ SUBSIS. ORIGIN } & \multicolumn{3}{|c|}{ PURCHASED ORIGIN } \\
\hline & $C L 3$ & CLA & CLS & CL3 & $C L A$ & CL5 & CL3 & CLA & CL5 \\
\hline$\ldots$ & $\ldots$ & $\ldots$ & $\cdots$ & $\cdots$ & $\ldots-\ldots$ & $\cdots$ & . & $\cdots$ & $\cdots$ \\
\hline \multicolumn{10}{|l|}{ ENERGY INTAKE } \\
\hline jul/aug'85 & 2455 & 2489 & 2587 & 553 & 1288 & 1253 & 1902 & 1201 & 1334 \\
\hline nov/dec'85 & 2577 & 2757 & 2569 & 718 & 1060 & 1093 & 1859 & 1697 & 1476 \\
\hline feb/mar'86 & 2408 & 2386 & 2745 & 437 & 717 & 1001 & 1971 & 1669 & 1744 \\
\hline may/jun'86 & 2675 & 2877 & 2793 & 654 & 428 & 774 & 2021 & 2449 & 2019 \\
\hline sep/oct'86 & 2378 & 2413 & 2595 & 821 & 1215 & 1255 & 1557 & 1198 & 1340 \\
\hline all rounds & - 2499 & $\cdot 2584$ & $\cdot 2658$ & $\cdot 637$ & - 942 & $\cdot 1075$ & $\cdot 1862$ & - 1643 & $\cdot 1583$ \\
\hline \multicolumn{10}{|c|}{ SEASONAL VARIATION } \\
\hline average deviation & 102 & 186 & 89 & 113 & 295 & 150 & 123 & 354 & 239 \\
\hline
\end{tabular}

@ CL3=coconut-cassava (N=95); CL4=cashewnut-cassava (N=90); CL5=livestock-millet zone (N=89).

much higher; evidently they compensate each other. The greatest variation in all respects (total, subsistence, purchased energy) occurs in the CL4 zone. In the earlier report this was attributed to a greater involvement in crop cultivation in this zone requiring greater peaks in energy expenditure and energy consumption (Niemeijer et al. 1991). Further analysis, however, does not sustain this. The high variation in CL4 is due to the highest peak in energy intake in May-June occurring in CL4-Kwale (Table 35), but this is an area with a relatively low rate of food cultivation. Moreover in the CL4-Kilifi area, which does have a high rate of food cultivation, the May/June peak in energy intake is not much higher than average.

\section{Income class}

The total energy intake per day in the households in the lowest income category (<sh1000/cu) is about $300 \mathrm{kcal} / \mathrm{cu}$ lower than in the higher income categories (> sh2000/cu; Table 38). The second lowest income class also has a low energy intake. The contribution of subsistence foods does not vary greatly; from 26-38 per cent for the different income classes. The two lower income classes indeed have a slightly higher percentage of energy from subsistence origin than average, although it still remains below $\mathbf{4 0}$ per cent of total energy intake.

In all income classes, the peak food consumption is in May-June (except in the wealthiest class where it occurred in July-August) and at this time the differences between classes become even larger, $500 \mathrm{kcal} / \mathrm{cu}$. The time of the lowest food consumption is less consistent but generally occurs in the period July-October and February-March, that is during the dry seasons.

The figures for energy from subsistence origin reveal that the lowest income class tend to spread their consumption of subsistence foods evenly throughout the year. In combination with a lower intake level they are able to keep down their food purchases 
Table 38 Seasonal variations in energy intake by income class (kcal/day/consumer unit) @

\begin{tabular}{|c|c|c|c|c|c|c|c|c|c|c|c|c|}
\hline & \multicolumn{4}{|c|}{ TOTAL ENERGY } & \multicolumn{4}{|c|}{ SUBSISTENCE ORIGIN } & \multicolumn{4}{|c|}{ PURCHASED ORIGIN } \\
\hline & $I C I^{\circ}$ & $I C 2$ & IC3 & IC4 & ICI & $I C 2$ & IC3 & IC4 & $I C l$ & $I C 2$ & IC3 & IC4 \\
\hline \multicolumn{13}{|l|}{ ENERGY INTAKE } \\
\hline jul/aug'85 & 2274 & 2542 & 2520 & 2895 & 1020 & 1162 & 766 & 1108 & 1255 & 1379 & 1754 & 1787 \\
\hline ec'85 & 2361 & 2721 & 2917 & 2767 & 882 & 1147 & 871 & 923 & 1479 & 1574 & 2046 & 184 \\
\hline feb/mar'86 & 2387 & 2495 & 2583 & 2670 & 684 & 726 & 629 & 808 & 1703 & 1769 & 1955 & 1862 \\
\hline 36 & 2508 & 2968 & 3019 & 2817 & 648 & 706 & 565 & 500 & 1859 & 2263 & 2455 & 23 \\
\hline sep/o & 2263 & 2337 & 2790 & 2685 & 1009 & 1142 & 1033 & 1194 & 1254 & 1195 & 1758 & 1491 \\
\hline all rounds & .2359 & $\cdot 2613$ & $\cdot 2766$ & $\cdot 2767$ & •849 & .977 & $\cdot 773$ & .907 & $\cdot 1510$ & •1636 & •199! & •1860 \\
\hline & & & & & & & & & & & & \\
\hline deviatior & 72 & 186 & 171 & 71 & 146 & 209 & 143 & 202 & 217 & 304 & 206 & 183 \\
\hline
\end{tabular}

@ IC1: <1000sh/cu (N=101); IC2: 1000-1999 (N=68); IC3: 2000-2999 (N=47); IC4: >=3000sh/cu (N=59)

most of the year. Only during the May-June period do they show an upsurge in intake from purchased energy. Households from IC2 show the greatest seasonal variation in energy intake from subsistence origin as well as purchased origin (although the latter is largely on account of an upward peak). The households in IC3 also have relatively low variations in subsistence energy and purchased energy, but in this group the variations do not compensate each other as in the lowest income group, and as a result the variation in total energy in IC3 is relatively high. In the highest income class seasonal variation in total energy intake is also low but this is achieved by other means. In this group food purchases are fairly constant over the year and vary the least of all groups. Because they can afford to do so they are less careful in spreading their subsistence consumption over the year which shows a fairly high variation, with the lowest food reserves in the May-June period.

\subsection{Conclusion}

Energy intake averaged $2580 \mathrm{kcal}$ per consumer unit or about 87 per cent of the estimated requirements. Almost 80 per cent of the energy is from carbohydrates (mostly maize), and the diet is rather monotonous with a low energy density (low fat content). Only onethird of the staple food consumption over the year is home-produced in origin and twothirds is purchased. This agrees with the low degree of food self-sufficiency earlier calculated from the production findings (p. 57). Maritim (1982) reported that expenses on maize in Coast Province in 1976-77 were higher than in all other provinces. This was confirmed in 1982 (CBS 1988).

Seasonal variation in this case starts with variations in energy intake from subsistence origin when food stocks are progressively depleted. The variation in subsistence energy is higher in areas where consumption of subsistence energy is high and where cassava con- 
sumption is low. Food purchases are the main way to compensate for the decreasing maize stocks, and they were highest in May-June, during the long rains, even enabling an increase of energy intake during the cultivation season.

In conclusion there are several findings that do not conform to the classical seasonality scenario. Most noteworthy is that there is no large energy deficit during the long rains. In the agro-ecological zones with the least agricultural potential energy intake levels were not lowest, neither were the seasonal fluctuations higher. While the households in the low-income class had the lowest energy intake, as expected, they did not show the highest variation because they succeed in spreading the consumption of their subsistence food more evenly than the other groups. The explanation for these contrary findings lies in the role of food purchases. Households in all zones and income classes depend to a large extent on income generation, which gives them an efficient coping mechanism allowing them, firstly, to preserve a large part of their food stocks throughout the year and, secondly, to purchase more food during the cultivation season when home stocks are running low. This agrees with observations by others that coping mechanisms consist increasingly of monetarization (Garine \& Harrison 1988b). Whether the food purchased reaches all members of the household or whether the peak during the long rains is meant for the 'workers' in the household is something that cannot be answered from the household estimates here. However, the findings in the next chapter in respect of weight gain of children during that period suggest that they also receive their share. 


\section{6}

\section{Nutritional Status of Women and Children*}

\subsection{Introduction}

Nutritional status was assessed for children between six months and ten years of age and the resident adult women who were the mothers of children in the survey. Women without children or whose children were outside the age group mentioned were not included, and as a result this population consists mainly of women between 20 and 40 years of age (The exact number of subjects examined during the successive survey rounds are listed in Appendix 6).

Measures of anthropometry included height, weight and age. For children under two years weights were measured with a Salter 235 scale (maximum $25 \mathrm{~kg}$ with an accuracy of $100 \mathrm{grs}$ ) and heights were measured in supine position on a wooden length board. For children under ten years weights were measured with a Teraillon digital scale (maximum $135 \mathrm{~kg}$ with an accuracy of $200 \mathrm{grs}$ ) and heights were measured in upright position using microtoises fixed to a standing metal rod with a wooden footpiece. The same equipment was used for the adult women. The anthropometric data were checked by members of the research team during frequent field visits. When data collected in the field were inconsistent (after comparison of weight, height and age) or when data collected in consecutive rounds were suspect, further field checks were made. Because records of birth registration were often missing, most age estimates were double-checked by members of the research

\footnotetext{
* This chapter is a revised version of Niemeijer, Foeken \& Klaver (1991, 37-47; 53-56; 58-77).
} 
team during the second round. An effort was made to keep the number of missing data as small as possible by means of return visits.

In the case of the adult women cross-sectional results are presented for each round. Average weight and height were calculated together with body mass index (BMI): the ratio of body weight $(\mathrm{kg})$ divided by squared height $\left(\mathrm{m}^{2}\right)$. The women were classified in categories above and below the cut-off point of $18.5 \mathrm{~kg} / \mathrm{m}^{2}$ which corresponds roughly to $90 \%$ of desirable weight and which can be regarded as grade (1) of chronic energy deficiency (FAO 1992).

In the case of the children, the conventional indicators weight-for-age, height-for-age and weight-for-height were calculated using the NCHS tables (WHO 1983) and the crosssectional results for each round were presented in the original study report. In addition, for each child growth rates between two survey rounds were calculated, and they are expressed as average centimeters per month (height growth) and average grams per month (weight growth). Growth figures were obtained by taking the difference of observed values at consecutive visits to the household and dividing the result by the number of months of the interval. When a child was absent during a particular round growth figures were not calculated for the prior and following interval but the child's growth rates were included for other survey intervals for which they could be calculated. The age reported is the age at the beginning of the interval.

\subsection{Adult Women}

The average weight of all women is $48.0 \mathrm{~kg}$ and the average height is $153.6 \mathrm{~cm}$ (Table 39). The average BMI is 20.3 and the percentage of women with indication of chronic energy deficiency (BMI<18.5; grade 1) averages 24.7 per cent throughout the year. These figures indicate women of relatively small posture who are also lean. The condition of the women is mostly stable throughout the year but in May-June there is an average weight loss of slightly more than $1 \mathrm{~kg}$ and a corresponding dip in BMI. Since these women were not reported to be more often ill at this time of the year the weight loss cannot be attributed to health factors. This time of the year is the period of planting and weeding during the long rains and as such the period of high labour requirements and high energy needs. Although the average weight loss is small, the percentage of women with chronic energy deficiency increases with 8-12 per cent. Quite a large number of women (30\% in all) were apparently on the edge of chronic energy deficiency, although this is more an indication of poor conditions throughout the year than of a seasonal emergency.

Table 39 also gives the measures of seasonal variation already used in the previous chapter: firstly, the maximum difference in BMI between rounds and, secondly, the average deviation in BMI per round from the mean over all rounds. The weight losses between rounds are not large; during the period May/June average weight is about $1.0 \mathrm{~kg}$ 


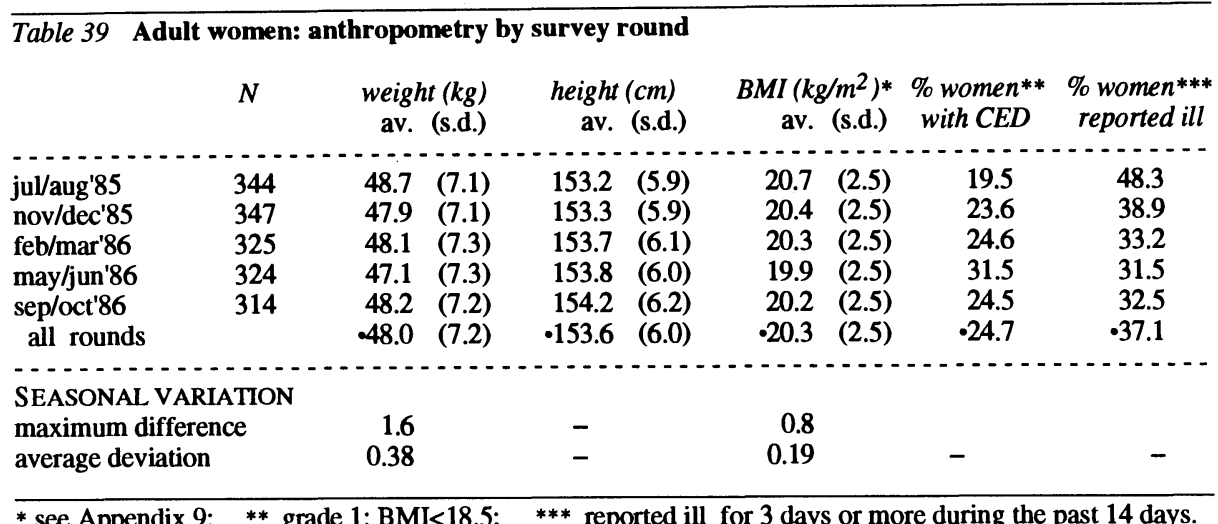

lower than in the immediately preceding and immediately following period. This is less than the weight losses that have been reported by others (p. 13) although the manners of calculation of the weight losses sometimes differ and are not always easy to compare. This, of course, was only to be expected after the previous findings that during the May/June period there is an increase in energy intake.

\section{Research areas}

The seasonal fluctuations in the BMI of mothers in the different study areas are shown in Table 40. In all areas there is a slight dip in weight in the period May/June but to different degrees. The largest seasonal variation occurs in CL5-Kwale. This is an area where food production is relatively high, and it is tempting to attribute the loss in weight (BMI) to the higher labour requirements because of crop cultivation. However, the women in the other area with high food crop cultivation (CL4-Kilifi) do not show such a large weight drop although household food consumption in this area is not higher (p. 76). The difference cannot be attributed to differences in labour demand either. In both areas the number of people available for farm labour is nearly the same (p. 55), the acreage under food crops does not differ substantially (p. 54) and returns per acre are not different either (p. 60). No easy

\begin{tabular}{lcccccc}
\hline Table 40 & Seasonal variation in nutritional status of adult women by research area @ \\
& \multicolumn{1}{c}{ CL3-Kwale } & CL3-Kilifi & CL4-Kwale & CL4-Kilifi & CL5-Kwale & CL5-Kilifi \\
BMI, average all rounds & 20.4 & 20.0 & 21.3 & 20.3 & 19.5 & 20.4 \\
max.difference & 1.0 & 0.4 & 0.7 & 0.8 & 1.6 & 1.2 \\
average deviation & 0.42 & 0.09 & 0.25 & 0.29 & 0.44 & 0.34
\end{tabular}

@ Detailed results in Appendix 9 (p. 114). 
explanation seems therefore available since there are no differences in income per consumer unit between the two areas either. The next highest fluctuation occurs in CL3Kwale and this is the area with the lowest rate of maize cultivation.

\section{Agro-ecological zone}

A breakdown of results by agro-ecological zone (Table 41) shows firstly that the nutritional status of the women in the CL3 and CL5 zones is slightly below that of the women in the CL4 area over the year. It is not quite clear why this should be so because food consumption (i.e. energy intake) in the CL4 areas does not differ much from the other areas (p. 78), nor is household income per consumer unit very different from that in the other zones (p. 65). In all three zones, the lowest level of nutritional status is reached in May/June. The lowest BMI occurs in the CL5 zone and is brought about by a very low figure of 18.4 for the CL5-Kwale area (Appendix 9).

The largest seasonal fluctuation occurs in CL5, the zone with the least agricultural potential of the three agro-ecological zones, which is also the area with the comparatively lowest level of nutritional status as shown above. In that sense the results seem to confirm the expectation that the women under the harshest circumstances will be most affected, although the fluctuations as such are modest.

Table 41 Seasonal variation in nutritional status of adult women by agro-ecological zone @

$\begin{array}{llll} & C L 3 & C L 4 & C L 5 \\ \text { BMI, average all rounds } & 20.2 & 20.7 & 20.1 \\ \text { average deviation } & 0.21 & 0.12 & 0.31\end{array}$

@ CL3=coconut-cassava; CL4=cashewnut-cassava; CL5=livestock-millet zone.

Detailed results in Appendix 10 (p. 114).

\section{Income class}

Women in low-income households generally have lower weights than women in high-income households (Table 42). In all income classes the lowest BMI during the year occurs in May-June, and it reaches the lowest level among women in income class 2 (IC2), followed by the women from IC1 and IC3 (Appendix 10). Surprisingly, the women in the lowest income class do not show a particularly poor condition at this time of the year. Closer inspection reveals that the women from different income classes cope with the seasonal labour peak in different ways. The lowest income class can only afford a very modest increase in household energy intake during that period. They also show hardly any drop in nutritional status at this time, which may mean that, unlike the women from the other income groups, they avoid the seasonal energy peak. This probably means that they limit their labour expenditure, which in turn will result in a low food production. And this may be one reason why they belong to the lowest income group, an example of the 'energy trap' again pointed out recently by Latham (1993). Following this line of argu- 
ment the women from IC2 and IC3 work more on the land to realize a higher food production, but they also have a higher food consumption during the cultivation period. The women from IC2 realize a higher food production than those from IC3 (p. 66), but they show less increase in energy intake during the cultivation season, which may explain the relatively higher weight loss among the women in IC2 than the women in IC3. The women from IC4 also work more on the land than women from IC1, judging from the higher food production in this group, and show a dip in BMI. But even at this time they stay above the average levels of the two lowest income groups during the rest of the year.

It could be argued that the higher seasonality figures in the case of women from IC4 have another meaning than those of women from IC2, since the former, on average, have a better nutritional status. If there are negative consequences from weight loss, the women from IC2 are more likely to suffer from them.

\begin{tabular}{lllll}
\hline Table 42 & \multicolumn{5}{c}{ Seasonal variation in nutritional status of adult women by income class @ } \\
& ICI & $I C 2$ & $I C 3$ & IC4 \\
BMI, average all rounds & 20.2 & 19.9 & 20.5 & 20.9 \\
average deviation per round & 0.12 & 0.38 & 0.26 & 0.34 \\
\hline
\end{tabular}

@ IC1: <1000 sh/cu; IC2: 1000-1999 sh/cu; IC3: 2000-2999 sh/cu; IC4: >=3000 sh/cu

Detailed results in Appendix 10 (p. 114).

\subsection{Young Children}

\section{General nutritional status}

To start with, the nutritional condition of the children in Coast Province aged 6-59 months, are compared with results from CBS-surveys held earlier in 1977, 1978, 1982 and 1987 (Table 43). The CBS findings and the findings of this survey are generally in accordance. Height-for-age as main indicator of long-term growth stays just below 92 per cent, but there is a difference between the CBS surveys and our results in respect of weight-for-height. The percentage of wasted children is higher among the study population. Since the percentage of children with low weights was consistent during five survey rounds there is no reason to doubt the present findings. In comparison with Kenya as a whole, the nutritional status of the children in the rural parts of Kwale and Kilifi is rather poor; the children in the two districts nearly always score lower. The percentage of stunted children $(\mathrm{h}-\mathrm{a}<90)$ and wasted children $(\mathrm{w}-\mathrm{h}<80)$ is much higher than the national figures, although the latest CBS survey of 1987 may perhaps indicate some improvement in respect of the latter. 


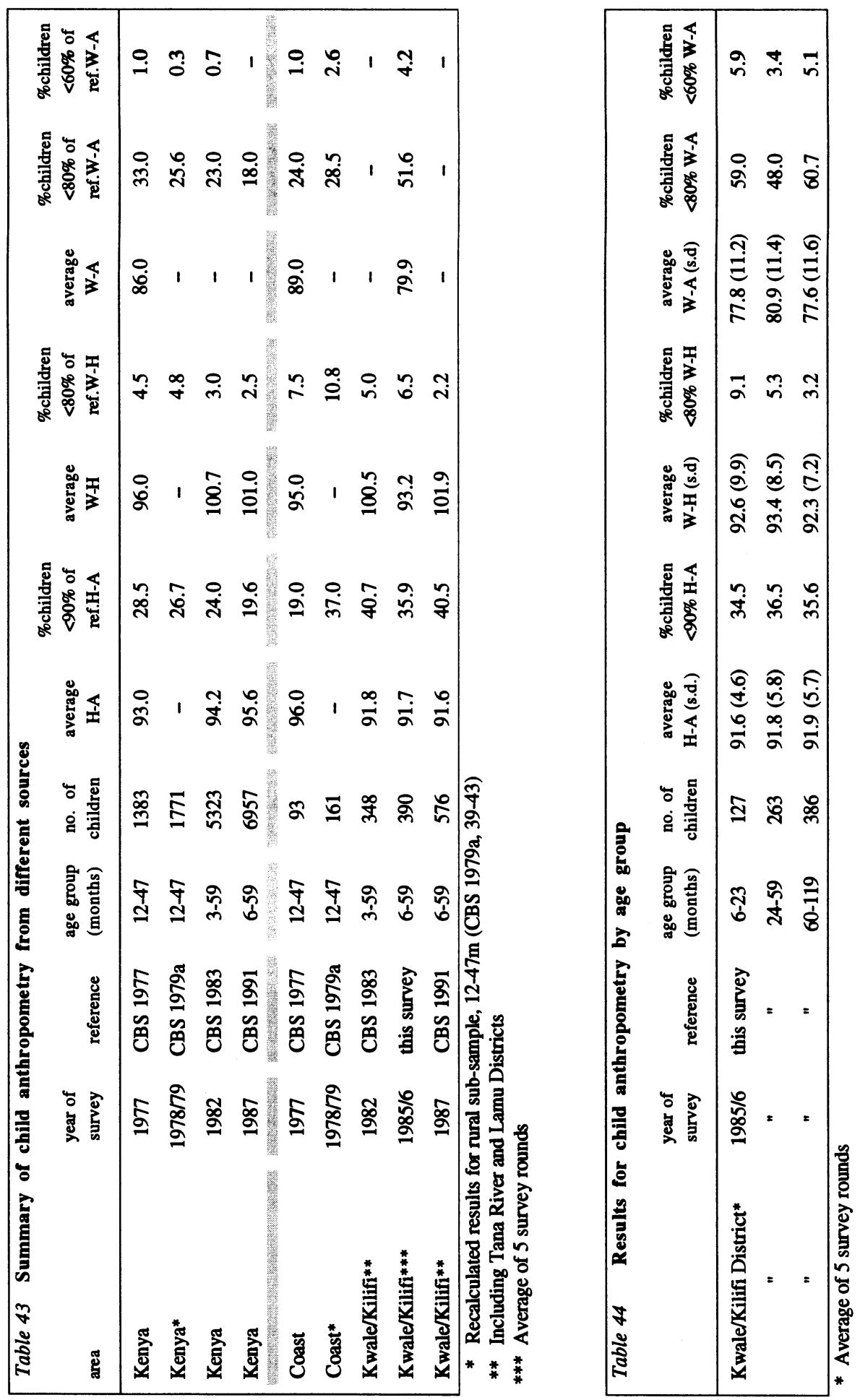


Table 44 gives a breakdown for the total study population in different age groups. In respect of height status the differences between the age groups are minute, average height-for-age and the percentage of stunted children are virtually identical. This means that the older age groups give no indication of catch-up growth to compensate for deficits that have occurred at younger ages. In respect of weight status (weight-for-height and weight-for-age) the results for the middle age group seem slightly better than for the two other age groups, but the difference is small and most likely a chance variation. It can be noted though that the variation in weight-for-height in the youngest age group is greater than in the older age groups. Young children are more susceptible to various illness and are also more dependent on the care of their mothers. The youngest group, 6-23 months, has a higher percentage of wasted children, 9 per cent, which is double that in the older age groups.

Information on the incidence of malnutrition at different times of the year is given in Table 45. In the two older age groups the incidence is fairly stable. Among the youngest children the percentage of malnourished children rises steadily to a peak of 8 per cent in June. Concordant is the fact that the younger children are reportedly more often ill than the older children. There is no confirmation, however, of a substantially higher incidence of illness during the rainy season in May/June among the youngest age group to explain the higher rate of malnutrition. It is not possible that a shortage of food as such is responsible for this, because household food consumption was shown to increase at this time of the year. There is no indication that a poor condition of the mothers themselves is responsible either, because the weight loss of women is small. A possible reason is that women at this time of the year can give less attention to their youngest children because they are busy in the fields. Peters \& Niemeijer (1987) have pointed to the relation between malnutrition and maternal behaviour in Coast Province. A study elsewhere in Kenya indeed reported a strong negative correlation between time spent on child care and time spent on food production, indicating that these two activities directly compete (Paolisso, Baksh \& Thomas 1990).

Table 45 Illness and malnutrition among young children by age group and survey round

\begin{tabular}{lccccccc} 
& \multicolumn{3}{c}{ ILLNESS * } & \multicolumn{3}{c}{ MALNUTRITION** } \\
& $6-23$ & $24-59$ & $60-119$ & $6-23$ & $24-59$ & $60-119$ \\
jul/aug'85 & 59 & 46 & 32 & 4.0 & 3.6 & 4.9 \\
nov/dec'86 & 60 & 39 & 31 & 4.0 & 4.2 & 4.4 \\
feb/mar'86 & 53 & 41 & 28 & 5.9 & 3.2 & 7.1 \\
may/jun'86 & 61 & 40 & 24 & 8.1 & 2.6 & 5.1 \\
sep/oct'86 & 54 & 39 & 23 & 7.4 & 3.5 & 4.2 \\
all rounds & .57 & -41 & .28 & .5 .9 & .3 .4 & .5 .1
\end{tabular}

* per cent children reported ill for 3 days or more during the past 14 days

$* *$ per cent children with weight-for-age $<60 \%$ (N-figures are listed in Appendix 6, p. 112). 


\section{Growth velocities}

The results discussed until now are cross-sectional in nature, but to analyse what may eventually turn out to be small seasonal differences it is more accurate to compare the measurements of individual children for different rounds. Since children are still in the process of growth which may be uneven in nature, the conventional anthropometric indicators (height-for-age but in particular weight-for-height) are less suitable for the analysis of seasonal variations. Any changes in these indicators are difficult to interpret because of the interdependence of the two 42 For that reason it is preferable to look at the growth rates of height and weight 43

In all three age groups height growth is at its maximum during the dry season, i.e. between December and February (Table 46). During this period, the average growth rate for children between six months and two years reaches a peak of $0.78 \mathrm{~cm}$ per month, children between two and five years old grow at a rate of $0.80 \mathrm{~cm}$ per month, and children between five and ten years old at a rate of $0.63 \mathrm{~cm}$ per month. For the older groups of children this is the only time of year when their height growth is above the reference value, but for the youngest children even this seasonal peak in length growth is still below normal growth for their age.

At the time that height growth is at its maximum, weight growth is at its minimum and less than half the reference value. Maximum weight growth takes place between March and May, i.e. during the long rains, with growth rates of 173 grams per month for the age group of 6-23 months, 200 grams per month for the children between two and five years old, and 240 grams per month for the oldest children. Again, even during the peak growth the rate for the youngest children falls below standard annual growth rate. But what is striking is the way in which the patterns of height growth and weight growth differ.

Table 46 Child growth velocities by age group and season

\begin{tabular}{|c|c|c|c|c|c|c|}
\hline & HEIC & HT GROWI & & WEIC & HT GROW & $\mathrm{HH}^{* *}$ \\
\hline & $6-23$ & $24-59$ & $60-119$ & $6-23$ & $24-59$ & $60-119$ \\
\hline aug>nov'85 & .64 & .57 & .45 & 167 & 124 & 102 \\
\hline dec $>$ feb' 86 & .78 & .80 & .63 & 98 & 65 & 101 \\
\hline mar>may'86 & .72 & .56 & .43 & 173 & 202 & 241 \\
\hline jun>sep' 86 & .62 & .53 & .48 & 172 & 144 & 181 \\
\hline all rounds & .69 & .61 & .50 & .153 & .133 & .156 \\
\hline reference value $* * *$ & 1.20 & .65 & .50 & 260 & 160 & 225 \\
\hline SEASONAL VARIATION & & & & & & \\
\hline maximum difference & .16 & $\begin{array}{c}.27 \\
0.515 \%\end{array}$ & .20 & 75 & 137 & 140 \\
\hline average deviation & $.06(9 \%)$ & $.09(15 \%)$ & $.07(14 \%)$ & $27(18 \%)$ & $39(29 \%)$ & $55(35 \%)$ \\
\hline
\end{tabular}

\footnotetext{
* cm/month; $\quad * * \mathrm{gr} / \mathrm{month}$ (N-figures are listed in Appendix 6, p. 112).

*** Based on the incremental growth tables of Baumgartner, Roche \& Himes (1986).
} 
The period of high weight growth is followed by a decreasing growth rate - leading to a minimum of 98,64 and 101 grams per month, respectively - during the dry period prior to the long rains. During the long rains the child's weight growth is at its peak and coincides with the high level of household energy intake shown earlier (p. 70). It is possible that the children above two years profit from the high level of household energy intake during that time of the year. The weight growth of the youngest children varies less with a minimum weight growth in the same period as the older children (December-February), but they do not fully follow the peak weight growth of the others in the following interval (March-May).

Table 46 also gives the familiar measures of seasonal variation; in this case calculated for the acceleration and deceleration in growth velocity during the different intervals. These calculations reveal several things. Firstly, the variations in weight velocity are considerable: $27-50 \mathrm{gr}$ variation or 18-35 per cent of the mean growth rate. The variations in height growth velocity are smaller: .06-.10 cm variation or 9-15 per cent. Secondly, the seasonal variations in growth velocity are much larger than the seasonal variations in BMI of the mothers that were reported in the previous section and that reach only one per cent of body weight. Thirdly, the seasonal variation in growth velocities are largest among the two older age groups and less among the youngest age group, which does not confirm the general expectation that youngest children are most affected.

\section{Environmental factors}

This section examines whether the factors, earlier analyzed for the adult women, are related to the seasonal fluctuation in growth velocity of children. For purposes of this analyis, the two older age groups, 24-59 and 60-119 months were merged since they show similar fluctuations. The results for the younger age group differ and the number of children in this group is too small to allow further analysis. Whatever differences will be found it is unlikely that they will still fit the seasonality scenario from which the study started. There is no seasonal drop in energy intake during the rainy season, neither is there an increase in child illness during that presumably critical period. There is also the pro

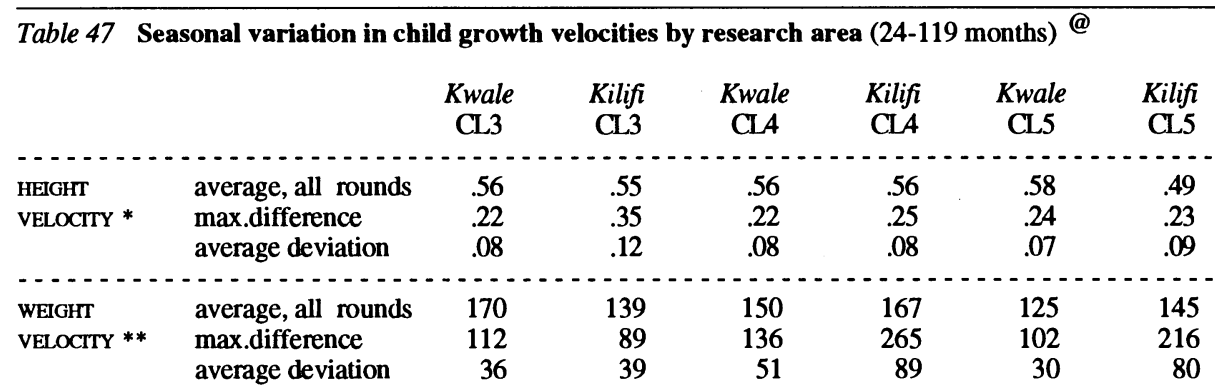

@ Detailed results in Appendix 11 (p.115); * $\mathrm{cm} / \mathrm{month} ;{ }^{* *} \mathrm{gr} / \mathrm{month}$ 


\begin{tabular}{|c|c|c|c|c|c|c|}
\hline \multirow[t]{3}{*}{ Table 48} & \multicolumn{6}{|c|}{ Seasonal variations in child growth velocities by agro-ecological zone (24-119months) @ } \\
\hline & \multicolumn{3}{|c|}{ HEIGHT VELOCITY* } & \multicolumn{3}{|c|}{ WEIGHT VELOCITY** } \\
\hline & $C L 3$ & $C L 4$ & CL5 & $C L 3$ & CLA & $C L 5$ \\
\hline average, all rounds & .55 & .56 & .53 & 148 & 160 & 136 \\
\hline average deviation & .10 & .07 & .06 & 38 & 66 & 57 \\
\hline
\end{tabular}

@ CL3=coconut-cassava; CL4=cashewnut-cassava; CL5=livestock-millet zone.

$* \mathrm{~cm} / \mathrm{month}$; $\quad * * \mathrm{gr} / \mathrm{month} \quad$ (Detailed results in Appendix 12-13; p. 116).

nounced seasonal difference in time of the year when maximum height and weight growth occur.

Results for the seasonal variations in growth by research area are presented in Table 47. Regarding height growth the areas show little variation. The average growth rate during the survey period was between .55 and $.60 \mathrm{~cm} / \mathrm{month}$ with the exception of CL5-Kilifi where it was slighly lower. There is also little difference in the extent of seasonal variation in height growth and CL5-Kilifi is no different from the other areas. The average weight growth showed greater differences between areas and was higher in CL3-Kwale and CL5-Kwale. The first is an area with a high household income and average energy intake, but the second area is characterised by relatively low incomes and low energy intake and shows a high degree of seasonal fluctuation. Another area with high seasonal fluctuation in weight growth is CL5-Kilifi. The latter area had a very low energy intake during the time when weight growth rate was low. The fluctuation in weight growth is noticeably less in the two CL3 areas.

The results by agro-ecological zone are presented in Table 48. Children in different agro-ecological zones do not show any differences in respect of average height growth, but the observed average weight growth in CL5 is slightly below the other zones for unknown reasons. The seasonal variations do not show a consistent pattern: the variations in height growth are largest in CL3, the variations in weight are largest in CL4 and CL5. In regards of both these factors it is also true that the yearly pattern shows some inconsistencies and it is likely that we are not dealing with systematic trends (Appendix 12-13).

The results analysed by income class are more consistent (Table 49). There are no differences in growth rates between children from different income classes. The average weight growth and the average height growth are about the same in all income categories,

\begin{tabular}{|c|c|c|c|c|c|c|c|c|c|}
\hline \multirow[t]{3}{*}{ Table 49} & \multicolumn{9}{|c|}{ Seasonal variation in child growth velocities by income class (24-119 months) @ } \\
\hline & & \multicolumn{4}{|c|}{ HEIGHT VELOCITY* } & \multicolumn{4}{|c|}{ WEIGHT VELOCITY ** } \\
\hline & & $I C l$ & $I C 2$ & IC3 & IC4 & $I C I$ & $I C 2$ & IC3 & IC4 \\
\hline aver & rounds & .54 & .57 & .51 & .57 & 147 & 142 & 157 & 144 \\
\hline average $d$ & viation & .11 & .06 & .04 & .06 & 58 & 40 & 60 & 22 \\
\hline
\end{tabular}

@ IC1: <1000 sh/cu; IC2: 1000-1999 sh/cu; IC3: 2000-2999 sh/cu; IC4: >=3000 sh/cu.

* cm/month; $\quad{ }^{* *} \mathrm{gr} / \mathrm{month}$ (Detailed results in Appendix 12-13; p. 116). 
despite the differences in energy intake that exist between low- and high-income households (p. 79). The pattern of growth is also quite similar. In all income classes the largest growth in height occurs during the dry season: between December and February a height spurt occurs, while during the rest of the year height growth remains on a substantially lower level. During the long rains, in the period March-May, weight growth accelerates and in the two high income groups continues in June-September.

The relationship between household income and the seasonal variations that occur in weight and height growth is more pronounced. Children in the highest income class show an average degree of seasonality regarding height growth and a low degree regarding weight growth. Children in the middle income classes show a low variation in height growth but have a larger seasonality in weight growth. It is the children in the lowest income groups who are most pronounced in their seasonal variations, in that both height and weight growth show large fluctuations. Apparently, these children grow unevenly through the year. It is possible that large seasonal variations in weight growth and height growth, when they occur differentially, can lead a child into at-risk conditions (Payne 1989). However, this is not confirmed by examination of the incidence of malnourished children, which only indicates that there are fewer malnourished children in IC4 (the number of children with $w-a<60$ is $4.4 \%, 5.8 \%, 5.5 \%$ and $1.3 \%$ respectively). To test precisely how often children fall below this weight level more observations during the course of the year are needed than were collected. A recent study in Mali also failed to find seasonal change in the prevalence of children at risk despite the presence of seasonal variations in growth velocity (Adams 1994). Nevertheless, since the annual growth rates that are realized by the children in the lowest income class are not below those of the other income classes, there are no indications that the greater seasonal fluctuation results in any negative effects in the long run.

\subsection{Conclusion}

The seasonal fluctuation in weight among this group of women is, on average, small. No systematic differences were found to exist in this respect between agro-ecological zones because of the coping by means of food purchases. Even though energy intake is greater in high-income households, this does not prevent a slight decrease in the women's nutritional condition during the rainy season in May-June. Rather surprisingly, the women of low-income households showed least seasonal fluctuation in BMI, even though or perhaps because they had the lowest level of food consumption.

In general, the nutritional condition of the children in Kwale and Kilifi Districts is poor. Compared with Kenya as a whole, the percentage of stunted children under five is almost twice as high. There was a slight seasonal increase in malnutrition among the youngest age group, 6-24 months, during the months of May/June. Among the other age 
groups there was little variation in incidence of malnutrition. All three age groups, however, showed large variations in growth velocities which were quite consistent among the two older age groups. Weight growth was highest between the third and the fourth survey rounds, i.e. between March and May 1986, namely during the period of the long rains, which is unlike what was expected from the general literature on seasonality. The strongest height growth took place a few months earlier between the second and the third survey round, i.e. during the dry season.

Payne (1989) has recently reminded us of the earlier research during the 1920-30s on seasonal growth in children in western countries. Here also seasonal changes in growth rates were reported with weight growth and height growth having different phases. Recently, attention has again been drawn to the irregular nature of child growth. Since growth occurs in spurts, a child may actually be growing in length for only 5-10 per cent of the time. In Europe, children are known to gain more height in the spring and more weight in the autumn. It is still a question to what degree the variation is innate and to what degree it is determined by seasonal factors such as food availability, disease or possibly sunlight (Waterlow 1994). The magnitude of the fluctuation, the synchronicity between the two and possible interaction are not yet clearly established, certainly not among children in tropical countries. Clinical findings tend to support the notion that weight gain precedes height gain. Some observations indicate that bone growth may occur at the expense of soft tissue growth, in such a way that the body becomes temporarily leaner (decreasing weight-for-height) while it grows in length (increasing height-for-age). An explanation may lie in two directions: the relationship can be conceived as (i) complementarity and/or (ii) competition. Complementarity exists if a certain amount of energy and nutrients have to be accumulated before a spurt in bone growth can occur, while the latter would enlarge the space available for body stores to be accumulated subsequently. Competition between bone ans soft tissues may also play a role (for instance, competition for sulphate). Whatever interpretation prevails, the question would still remain how length growth is regulated. Hormones and hormonal growth factors undoubtedly play a role, physical activity may act as a stimulus for bone growth, while it is also possible that a biological clock is involved.

Interaction between weight growth and height growth can take the form of a kind of 'time management' by the body: doing tasks in batches leading to increased efficiency. An increase in body weight leads both to an increase in basal metabolic rate and to an increase in expenditure for moving a larger body during physical activity. A growing individual can save some energy by retarding weight growth compared to height growth during a growth spurt. While weight may subsidize height growth in this way, the reverse is not possible. This implies that when there is a stress on body mass, a decrease in relative weight (weight-for-height) will occur. In the end, however, stress will also compete with any subsidy for height growth and after some time growth retardation in height ensues. This sequence of events is widely accepted. It has led to the speculation that on the positive end of the spectrum (active growth), it is weight growth that regulates height growth, 
"as if there were a bag which has to be filled up before it can increase in size" (Waterlow 1994, S73). Results from nutritional rehabilitation studies seem to point in this direction. For instance, in earlier work on intervention in child nutrition elsewhere in Kenya it was found that malnourished children with a low weight-for-height generally recovered weight more and height less than controls from a normal population (Hoorweg \& Niemeijer 1989). The children in better condition ( $w-h>85)$ showed greater height gains and lesser weight gains. Walker \& Golden (1988), in turn, report that malnourished, stunted children in Jamaica show greater length growth during recovery. In Nepal weight and height gains were related in different ways to initial weight-for-height: among children who were initially wasted there was very little height gain, but maximal weight gain; while children with a better weight-for-height did grow well in height but not in weight (Costello 1989).

In the absence of control groups, statistical artefacts may also play a role. Firstly, there is 'regression to the mean', meaning that those who are low in weight at the start tend to be less low on second measurement, and those who start high tend to become less high. Secondly, measurement errors in height may have contributed to the apparent positive correlation between height gain and weight. Individuals who appeared wasted due to a positively biased height reading would tend to have an underestimated length increment and vice-versa. Haaga (n.d.) have shown this to occur in cross-sectional studies, but it may equally apply to longitudinal data.

As for the results of the present study: the opposed seasonality of weight and height growth stands out. This is consistent with the notion that even normal growth is not a regular process but an irregular one. But this also makes it difficult to separate variation due to negative external factors from natural biological variation. Nevertheless, meaningful information can still be drawn from differences between subgroups within the existing material. The fluctuations in weight growth are relatively larger than in height growth and they are of lesser magnitude among the youngest children and largest among the oldest age group. The growth figures and seasonal growth fluctuations do not indicate consistent differences among children from different agro-ecological zones. The average weight growth and height growth of the children is also the same for different income categories. However, among the children from different income classes the growth fluctuations differ. In the relatively prosperous households, the children grow quite evenly throughout the year, but in the very poor households, both weight growth and height growth are very uneven indeed and in this way these children are possibly more at risk although this was not studied in detail.

Another interesting finding is that the peak in height growth seems to precede rather than follow the peak in weight growth. The peak height growth occurs in DecemberFebruary, followed by a weight spurt in March-May while in the period May-November the growth rates for both weight and height are relatively modest. It seems unlikely that a child will increase in weight and that the height spurt will only follow half a year later. 
This calls into question whether the model of the 'bag which has to be filled up' can really be the whole explanation.

In view of this lack of clarity on the mechanisms of growth we can only speculate about the role of external factors such as seasonal illness, food intake or possibly sunlight. There is no seasonal pattern of illness that can be related to either the weight or the height spurt or the absence thereof, although the illness information was not detailed enough to be definite about this. As regards food intake, the weight spurt occurs at the time when household energy intake is higher than during the rest of the year. Perhaps, the children benefited from the high household energy intakes, although it is not certain that this extra food did in fact reach them, because it is presumably meant for the 'workers'. Household energy intake increases with $200 \mathrm{kcal} / \mathrm{cu}$, which amounts to $100 \mathrm{kcal}$ for a child, aged 2-5 years. Such a modest increase in energy intake could theoretically support an extra weight gain of $135 \mathrm{gr}$, which compares with an increase in weight velocity of $138 \mathrm{gr}$ during the months of March-May compared with December-February 44 As regards the last factor that was suggested: in Europe, spring is a time with more sunlight and autumn a time of less sunlight. The seasons in the Kenya Coast are very sunny and dry in DecemberFebruary when the height spurt occurs and rainy and often clouded in March-May when the weight spurt occurs. Further research is needed to address these issues but it is important to know that at any one time either height or weight lags relatively behind the other and that often one is being compensated as a matter of course. 


\section{Discussion}

Traditionally, the Mijikenda did cope with seasonal food shortages or famines in many ways: collecting wild plants, hunting, collecting and selling forest products, trading, and with the help of social networks and exchange with neighbouring tribes. In particular, trade was an important element in the Mijikenda economy, and it took three forms: firstly, the usual exchange of surplusses - like grains, palm wine, clay pits, salt, and livestock - for necessary goods produced by others; secondly, the sale of forest products, with or without processing; and thirdly, acting as middlemen in the long-distance trade between the interior and the coastal towns. During the nineteenth century, many Digo, Duruma, Rabai and Giriama traders participated in the ivory trade and became quite wealthy. Gradually, however, the Mijikenda lost their profitable middlemen position, first to Kamba, later to Arab and Swahili, and finally to English and Indian traders. The completion of the Uganda railway (1901) ended the caravan trade completely.

But other forms of trade went on, at least for some time. In good years, the Mijikenda were able to produce important maize surplusses with which the coastal towns were fed. In poor years, which occurred on average once a decade, forest products were exchanged for grains which the Swahili traders imported from other places along the East African coast. Over the past century, however, opportunities in both agriculture and trade have seriously declined. Hunting and the ivory trade were forbidden by the colonial government. The collection of forest products like copal, orchilla and wild rubber was regulated and later be- 
came unprofitable because of falling prices. Grain exports declined as well, partly due to natural causes (droughts, floods, locusts) between 1925 and 1937, partly due to falling prices in this period, but also because of trade regulations by the government (quality control, cheap railway and shipping rates for maize from the white settler areas). In fact, only two rewarding items were left open to the Mijikenda, copra and palm wine, although this trade was also troubled by government regulations. It explains why, since the $1920 \mathrm{~s}$, the distribution of coconut palms in the two districts has expanded enormously and why many people migrated from the drier areas in the hinterland to the coconut zones. Finally, heavy hut taxes (especially from 1921 onwards), that had to be paid shortly after the harvest, forced many Mijikenda to sell maize when prices were low and to buy maize for food later on when prices were high.

The results of these and other developments have been that the two districts are unable to feed themselves, despite the expansion of cassava production since the 1940s and the growing importance of rice, which can be grown on wet land unsuitable for maize. By the early 1980 s, 50,000 tons of maize had to be imported yearly into Kilifi District alone from other parts of the country (MENR 1984a). This equalled about half of the total requirements or $100 \mathrm{~kg}$ per head of the population (Waaijenberg 1994).

In most of Sub-Sahara Africa, farmers have been incorporated in the money economy to a greater or lesser extent. Ready cash is needed for school fees, clothes, housing as well as certain food items such as tea, sugar and cooking fat, not to mention various luxury items. In the case of Coast Province, as we have seen, substantial amounts of money are furthermore required for food purchases, because of the structural deficits in food production. Sales of cash crops and livestock products are one way of earning an income, offfarm employment another.

Households seek a balance between their resource base on the one hand and their consumption needs on the other. In terms of nutrition, this means that the level of food consumption is determined by the demand for food on the one hand and the supply of food on the other. The demand for food is a function of the physical needs and fluctuates along with the amount of labour to be done. Labour requirements during the agricultural cycle are an important cause of these fluctuations and since agricultural labour is mainly done by women (especially food production), women are usually expected to show the largest fluctuations regarding food requirements. The supply of food is determined by two factors: the household's own food production and the amount of food that can be bought. The latter is a function of the monetary income that can be realized.

\subsection{Resource Management}

Successive surveys reveal a declining importance of farming in the districts and a growing importance of wage employment, although agriculture still remains an important component of the local economy. Agriculture requires access to land and in this respect there did exist traditional mechanisms to spread risk. One is the local practice of cultivating different plots 
of land in different areas, often in different agro-ecological zones. This reduces the risk from unreliable rainfall and also offers the opportunity to spread labour more evenly throughout the year. In the locations studied in this report we have found little evidence of this practice. Most people had their lands within one hour walking distance and there were few seasonal movements of households to other locations. In long-settled areas such as the Kaloleni area in Kilifi District, a system of land-lending existed previously by which the 'lender' was permitted to use the land in return for some symbolic payment. However, "with increasing monetization and market penetration, this mode of diversification has come under increasing strain; the economic value of such exchanges is increasingly emphasized, their social function discounted" (Geist 1981, 108).

\section{Subsistence crops}

Maize is the primary staple food grown in the region. It outranks by far sorghum and millet, which are more drought-resistant and were traditionally grown, but which have become less popular for various reasons. Efforts to reintroduce these crops have met with little success until now. Another crop is cassava. Among the Digo cassava used to be the main staple but it has also been relegated to a lesser position than maize. In many parts of Africa cassava serves to overcome periodic food shortages, either during the annual season of food shortage or during relatively dry years. The results of the present survey, however, indicate that even during the cultivation season when maize stocks are low, households tend to rely on buying maize more than on consuming their cassava crop, much of which is left in the ground. Nonetheless, the food is there in quantity. Some tree crops like coconuts and cashewnuts may also serve as a 'hungry season' crop; particularly coconuts because these can be harvested all year round. During the last decades, the function of the tree crops has shifted from secondary food crop towards cash crop, but in a way this has the same purpose namely to enable food purchases.

Modern cultivation methods will help to increase food production. Improved varieties of maize like Coast Composite and Pioneer Hybrid have been introduced long ago. Higher inputs (like tractor or ox-ploughing, fertilisers, seeds of improved varieties, plant protection methods, etc.) lead to much higher yields but also to higher risks and very few smallholders have adopted them. Geist $(1981,170)$ already noted that in Coast Province smallholders "perform strikingly poorly, illuminating the low productivity in food production". Furthermore, there is little difference between the various ecological zones: the major input remains labour.

\section{Cash crops}

The main cash crops are coconut palms, cashew trees and fruit trees, but altogether they account for only ten per cent of the average household income. Also the development prospects of cash crops were not good, widespread cutting down of cashew trees was reported at the time because of poor payments to farmers. A fruit processing plant that was started in Mtwapa around 1988 soon ran into problems. The coconut palm still acts "as a buffer in the otherwise insecure economy of the Mijikenda, (...) because of the reliable 
yield of a variety of products which are in continuous demand for home consumption and sale (...)" but the annual income per palm tends to be low (Waaijenberg 1994, 236).

Nevertheless tree crops remain a potential asset and can also serve as a means of redistribution. Trees are mortgageable, i.e. the rights to the produce from trees can be loaned by the owners in exchange for some symbolic rental. This practice was not only widespread in the Arab coconut plantations in the coastal strip after slave labour was abolished, but also among the farmers in the African hinterland. In the southern part of Kilifi District, coconut and doum palms have traditionally been mortgaged by the Giriama as part of the indigenous mechanisms for spreading risks. But land tenure reform and commodization have discouraged the separate ownership of land and trees (Ciekawy 1988).

\section{Livestock}

Mixed farming is also a form of adaptation, rearing livestock in addition to crop cultivation. Especially in the drier zones, keeping livestock was traditionally an important means of existence because it constitutes an asset to overcome periods of food shortages. Most of the local cattle are found in the hinterland under traditional rangeland and husbandry systems. Borrowing cattle and its corollary, the fielding out of cattle with relatives and friends, seems to be a common practice, and this form of spreading risks via social relations is not without significance. The caretakers can generally use the milk for own consumption. When the owner needs one or more cows, for instance to pay for school fees or a marriage expenses, they are returned. In the hilly range nearer to the coast and in the coastal plain there are fewer cattle and the occasional herd is small in size. Most of the improved dairy cattle are found here, mainly on medium and large-scale farms. Smallholders in the coastal region tend to sell milk directly to households, shops (local) hotels and through hawkers. Studies indicate that milk production and consumption levels are low (CBS 1981b;1983). Recent attempts at stimulating commercial small-scale dairy production have been successful to some extent, but both the farmers involved and their customers belong to the betteroff households in the district and this form of milk production does not appear to be of great importance for the poorer segments of the population (Hoorweg \& Leegwater i.p.).

\section{Employment}

According to official statistics, employment opportunities in the region are limited, and Waaijenberg (1987) was of the opinion that during the 1980s it became increasingly difficult for individual households to find off-farm employment. Employment opportunities also depend on the skills that workers have to offer. Educational levels in Coast Province, however, are lower than in other parts of the country (CBS 1994) and there is no reason to expect that the situation is different in respect of specific job training. Nevertheless, successive surveys reveal a growing importance of wage employment. In 1981/82 salaries and wages contributed 45 per cent and 43 per cent of the average household income in Kwale and Kilifi, respectively (CBS 1988). The results of the present survey give even higher figures, namely that, on average, off-farm employment accounts for 60 per cent of the 
household income. Most households have some income from agriculture; only 26 per cent reported no income from off-farm employment.

Many wage labourers work in Mombasa or elsewhere in the coastal strip in the hotel areas, or in towns like Kilifi and Malindi, and live away from their homes. Only people from areas with good transport connections can commute to their work and live on the farm. Women often work for other farmers, especially in land preparation and weeding. The contribution of remittances from family members who are living elsewhere but who are still considered as members of the household was not investigated in this survey; but its estimated contribution to household income is modest, less than ten per cent (CBS 1988).

To achieve a balance between food supply and consumption the whole year round, rural households generally prefer to utilize diverse resources. To counter the risks inherent in agriculture one or more household members will seek wage employment of some kind. In turn, cultivation of cash crops safeguards against unemployment and subsistence crops may ease food expenses. The actual resource mix is decided by internal factors such as land ownership and available labour and external factors such as agro-ecological conditions and employment opportunities. Emphasis on crop cultivation demands access to land, high labour inputs and hard work during the cultivation season, and carries risks because of climatic uncertainties. Emphasis on employment demands that at least some household members have skills that are wanted on the labour market. More in general, it requires sufficient employment opportunities which are sometimes themselves seasonal in nature and also carry risks in the form of fluctuations in wage levels but also in price levels of foods.

\subsection{Seasonality in Nutrition}

In short, the classical seasonality scenario is as follows. At the end of the dry season and during the rainy season food stocks are running low, food prices increase and food consumption decreases. During the rainy season the food energy needs of people are higher because of heavy work in the fields. At the same time the exposure to disease is high because of the wet conditions. Since women do most of the agricultural cultivation and children are most vulnerable to disease, the nutritional status of these groups will go down. When the harvest is in there is a peak in food consumption to compensate for the previous losses and nutritional status recovers. In the present study, however, the results do not fit this scenario. Although food stocks were indeed lowest at this time of the year, the 'average' household managed to purchase sufficient food so that the household energy intake even showed an increase during the long rains and no consumption peak in the harvest season.

There is obviously good reason for this differing pattern. The seasonal fluctuations described in many studies often concern subsistence farmers, i.e. farmers who are not in a position to buy the food that is needed when own stocks are depleted. Under such circumstances it is rational for farmers to increase food consumption in the immediate post-harvest 
period, so as to quickly fill their body's energy reserves that were depleted by the combination of low food intake and high physical activity in the previous growing season. The food thus consumed is then safe from food storage losses as occur in the granary. In so doing they also make sure that their body weight is maximal at the start of the next growing season (Payne 1989). This strategy involves a strong seasonal fluctuation of body weight. Recent evidence has shown that this pattern is far from universal in rural areas of developing countries. In some areas, physical activity may be rather evenly spread throughout the year, thus attenuating the effects of a seasonally low food availability (Ferro-Luzzi 1990). There are also situations where food intake does not follow the seasonal fluctuation of food availability, but rather goes hand in hand with variations in energy expenditure. The latter case is thought to occur in a situation where there exist increased opportunities for filling the gaps of the household farm production calendar, either with improved varieties of food or cash crops or with off-farm employment and where, for example, there is no evidence of post-harvest feasting (Payne (1989) gives the example of the Myanmar in Burma). It is to be expected that this relationship is even stronger when a large proportion of the food is actually bought. Regarding the present study, this would explain why in May-June, when stocks are low and labour needs are high, energy intakes are high as well, while in JulyOctober, when stocks are high, energy intakes are low. It would also fit with the small increase in consumption during the short rains in November, when energy requirements again rise for some farmers.

As a result it is not surprising that variations in the nutritional status of adult women do not conform to expectations. The present survey measured changes among adult women with young children, who can be expected to have the heaviest work load because of the combination of agricultural cultivation, domestic chores and the care for young children. Although these women showed a dip in BMI during the rainy months, the weight loss incurred was small, on average only one kilo. There is no reason to suspect that the increase in household food consumption does not reach the women. Therefore, the loss indicates that the increase in household food intake at this time of the year is not sufficient to meet the higher energy requirements. The deficit, however, appears to be small because only minor losses in nutritional status occur. Under certain conditions, among certain groups of women the weight loss was higher, as we have seen.

The nutritional condition and physical development of children depends to an important extent on household food consumption and health conditions. The average household energy intake is below the estimated requirements. The health situation in Coast Province is also unfavourable judging, for instance, from the high prevalence of malaria. As a result, the nutritional condition of the children in Coast Province is poor. Compared with Kenya as a whole, the percentage of under-fives who are stunted is almost twice as high.

As among the adult women, the seasonal variations in nutritional status of children, in particular weight-for-height, did not conform to expected variations. The prevalence of malnutrition shows a consistent seasonal pattern in only one age group. Among the youngest children, aged 6-23 months, the percentage of malnourished children started to increase in February-March '86, reached a peak in May-June and was still high in October- 
November, probably because the earlier affected children were still recovering at that time. In other age groups, however, patterns were less clear. All children showed seasonal patterns in growth, but they were timed differently for weight and for height and did not conform to the expected seasonality pattern. Height growth was at a maximum during the first months of the dry season, the period December-February. At the time that height growth was high, weight growth was low. The maximum weight growth occurred during the months March-May, the period of the long rains, and this is quite contrary to what was expected. The acceleration in height growth occurred at a time when the incidence of infectious disease tends to be low and weight growth accelerates at a time when household food consumption is highest, but it is not possible to establish direct connections between these diverse phenomena. It is quite logical that weight growth follows height growth spurts or vice versa - the one necessarily following on the other.

\subsection{Determinants of Seasonality}

Several factors were mentioned in Chapter 2 that are expected to determine the degree to which the adverse effects of climatic seasonality are felt and the type(s) of coping mechanisms that can be used. These factors are: the dryness of the climate, the form of productive organization, household income level and individual characteristics.

\section{Climate}

The hypothesis that climatic seasonality tends to be stronger as annual precipitation is lower, was not confirmed in the case of Coast Province. There appears to be no correlation between mean annual rainfall on the one hand and the (climatic) seasonality index on the other (Foeken 1994). That does not alter the fact, however, that with the same degree of rainfall variability, in drier areas rainfall will be less than the critical level for agriculture more often than in wetter areas. In other words, rain-fed farming in the former areas is more risky than in the latter. And although a poor harvest as such is something else than seasonal food shortages, a poor harvest in one year can easily lead to more seasonal stress than what is 'normally' experienced in the year thereafter. The study revealed no relation between annual precipitation and variability in food consumption or nutritional status. Absolute levels as well as fluctuations in energy intake and in the women's weight-forheight did not decrease as the climate was drier.

\section{Productive organization}

Although the households in all six areas are integrated in the monetary economy, the extent to which they depend on a money income is not the same. For the households in the rural coast areas the choice is between two main strategies: farming and wage employment. The farmers in the CL3 zone near the coast can grow a range of food and cash crops, with fairly good yield potentials. Crop choices of the farmers in the CL5 zone are more restricted and yield potentials are less. In the latter zone, prospects for livestock rearing are fairly good, 
although 35 per cent of the households did not own any livestock. It was expected that coping mechanisms in the drier areas would differ a great deal from the other areas. The study revealed, however, that traditional coping mechanisms in the agronomic and social sphere have to a large extent given way to economic mechanisms in the form of wage employment, thus confirming what was earlier noted by Garine \& Harrison (1988b). The balance between the different types of strategies, agriculture vs. wage employment, is to an important extent determined by two factors that have little to do with climatic conditions, but rather with the availability of off-farm employment and the amount of labour in the household. The two areas that differ most in this respect, the CL3 and CL5 locations in Kwale District, which were studied by Oosten (1989) in detail, are examples. In the CL3 location subsistence farming is marginal: on average, only 17 per cent of the households' energy intake was derived from home production. Sixty percent of the adult men and 25 per cent of the adult women were engaged in some type of non-farm activity. As a result, 75 per cent of the average household income came from these activities. In the CL5 area the latter figure was much lower (36\%), mainly due to the low participation rate in off-farm activities (35\% of the adult men and none of the women). Compared with the other areas, subsistence farming was quite important: 58 per cent of the energy intake was homeproduced. Nevertheless, the levels of food consumption between the areas differed little.

\section{Household income}

Although it is generally assumed that household income is an important determinant for seasonality, the present study shows that the relationship between this factor on the one hand and food consumption and nutritional condition on the other is not straightforward. Energy intake (and protein intake as well) was indeed low in the poorer households but energy and protein intake in the lowest income group were comparatively stable throughout the year. Chambers et al. (1979) have called seasonality firstly a problem of the poor and powerless. The present study does not confirm this except in a roundabout way, and there are two reasons for this. Firstly, because of the availability of food that can be purchased households are able to realize an energy intake that is more or less synchronous with varying energy needs. Secondly, the seasonality in energy intake therefore takes the form of a peak during the cultivation season, rather than a dip due to low intake levels. Still, it is true that the poor households show the lowest peak in energy intake during the cultivation season, and it is tempting to hypothesize that this will result in a low level of agricultural production, in combination with a lack of other income sources. Agricultural returns in this group were indeed low. Women in the lowest income group also showed a relatively low nutritional status throughout the year compared with the two highest income classes. In that sense one could consider this group "to be trapped in a circle of malnutrition and low activity" (Gill 1991, 48).

The income level of the household had no clear impact on the average growth level both weight and height growth - of the children, but it did have a relation with the seasonal fluctuations of their growth. Children in the high-income households had a low degree of seasonality regarding both weight growth and height growth, compared with the 
children in the low-income households. The latter children showed an unstable growth pattern, both in weight and in height, although there is no proof that these unstable growth patterns carry dangers because the average growth over the whole period of study is not different.

\section{Age and gender}

Generally it is postulated that women and young children will show the greatest seasonal variations in nutritional status. Women, because in Sub-Sahara Africa they do most of the work involved in food cultivation and because of conditions inherent in motherhood, namely pregnancy and breastfeeding which make high demands on her body. Children, because they are most vulnerable and more prone to infectious diseases. The present study did not focus on these aspects in particular. No attempt was made to measure individual food consumption which would have been necessary to address these issues, but the results for nutritional status offer some partial insights.

The nutritional status of women fluctuated only modestly. Even at the time of agricultural cultivation the loss in BMI is not large, and less than reported in other studies, which can only mean that a substantial part of the higher energy consumption during this season indeed goes to the adult women. These results are the more convincing because the women studied were mostly in the range of 20-39 years - child bearing age. Data on adult men were not collected in this case, but there are findings under very different conditions in Benin among a remote rural population largely without off-farm income, where larger weight losses occurred. In that study the men showed equal if not greater weight loss than the women during the cultivation season (Liere et al. 1994).

The seasonal fluctuation in growth velocity of young children are comparatively larger than the fluctuations in BMI that occur among the adult women, although they could not be directly related to fluctuations in food consumption. There were differences in velocity fluctuations among children from different age groups, with the children over five years of age showing larger fluctiations in weight and height growth than younger children, particularly children below two years of age. These differences occur independently of the growth standards for the different age groups. However, as already mentioned, the meaning of the fluctuations in growth velocity are unclear and require further study.

\subsection{Implications}

The main revelation of this study is the low level of seasonal fluctuations in total caloric intake and the minor seasonal fluctuations in nutritional status. In this part of the country which is relatively dry, has a low degree of food self-sufficiency and where households have low income levels - profound seasonal hardship could certainly be expected. However, households manage to purchase sufficient food to cover the diminishing food stocks from the previous harvest. During the season of crop cultivation the caloric energy 
intake in all groups even increases, although probably somewhat less than the heavy labour at this time of the year would require.

This can only be so if, firstly, there is a sufficiently fine marketing network through which maize is distributed and if, secondly, food prices do not rise to such an extent that they become unaffordable by local households. At the time, maize pricing and maize movements were officially regulated by the Kenyan Government. Food prices were kept low for many years and maize movements were the responsibility of the National Cereals and Produce Board and its appointed wholesalers. This system received many criticisms over the years because, it was argued, it strained food supply and raised prices artificially in areas such as the coastal districts (Meilink 1985; 1987; Gordon \& Spooner 1992). These negative effects, however, seem not to have played a significant role in the study areas at the time, because most households were able to purchase sufficient food to compensate the decreasing food stocks despite low income levels. Local duka's were indeed provisioned by wholesalers with small pick-ups, and although food prices did increase during the rainy season, prices did not become exorbitant. The liberalization policy that was implemented since then was generally expected to lead to better food distribution by private wholesalers, but also to higher maize prices. Consumer maize prices did indeed rise strongly since 1992 (GOK 1993; 1994b), and it is important to find out what has actually happened in the areas under these conditions.

In two recent policy papers the Kenya Government has again emphasized the need for food self-sufficiency in basic staples and the importance of household food security (GOK $1994 a ; 1994 b)$. It is unlikely that food self-sufficiency can be realized in the coastal areas and it can even be questioned whether this would be desirable given the soil and climate conditions and the resulting high costs. The climatic conditions do not assure sufficient maize harvests every year, or even nearly every year, and the second main staple, cassava, is clearly no longer preferred by the population. This is not to say that food production cannot be increased. There are indications that productivity in certain areas of the coastal plain stays behind because of the competition from off-farm employment. The seminar that was organized with district personnel to discuss several studies came up with many recommendations to improve agricultural production, notably concerning the introduction of drought-resistent crops, improved support by extension services and greater access to agricultural inputs 45

The sessional papers rightly link food security closely with income from cash crops and employment. Where in other parts of the country cash crops yield considerable incomes, for the coastal households food security depends to a large extent on food purchases that will have to be sustained by income from employment. This dependence on food purchases, however, means that any serious distortion in food supply or food prices can seriously upset the balance, because they cannot easily be compensated by subsistence cultivation or extra employment. Greer \& Thorbecke $(1986,136)$ already reported out that the coast population are large net purchasers of maize who will experience "real income losses from a rise in the price of maize". In order to raise the general standard of living in this part 
of the country, a strong policy directed towards increasing off-farm employment, especially in the so-called informal sector, is necessary.

As regards the influence of environmental factors, little difference was found to exist between agro-ecological zones, neither in household income, food consumption, nutritional status nor in seasonal variations that occur in the latter two. Earlier studies have tried to link nutrition with agro-ecological conditions but usually with little success (CBS 1979b; Haaga et al. 1986). At least, within the coastal region, the targeting of specific zones for income and nutrition measures will not be effective. This is also indicated by the large differences that occur between areas within the same agro-ecological zones. Income class is a more important factor for targeting purposes. The low-income households show little seasonal variation but also show a low energy intake during cultivation time, which raises concerns about the ability of this group to put sufficient effort into food cultivation - a possible 'energy trap'. Particularly, since poor households generally have to depend more on subsistence production. This is certainly a reason to aim at increases in food production, although the possible measures that can be stimulated are limited because households can usually not afford to purchase the necessary farm inputs.

It can be concluded that the population in the two districts have developed fairly successful strategies to cope with diminishing food stocks at the end of the year, despite the fact that household income levels are generally low, that a large percentage of households falls below poverty levels, that household energy intake is not above that of peasant smallholders elsewhere in Kenya, and that the nutritional status of children is below that in other districts. The potential for increasing agricultural production remains limited, given soil and climatic conditions. Future development policy and efforts to promote food security should consider wage employment an important priority. 

Appendices 


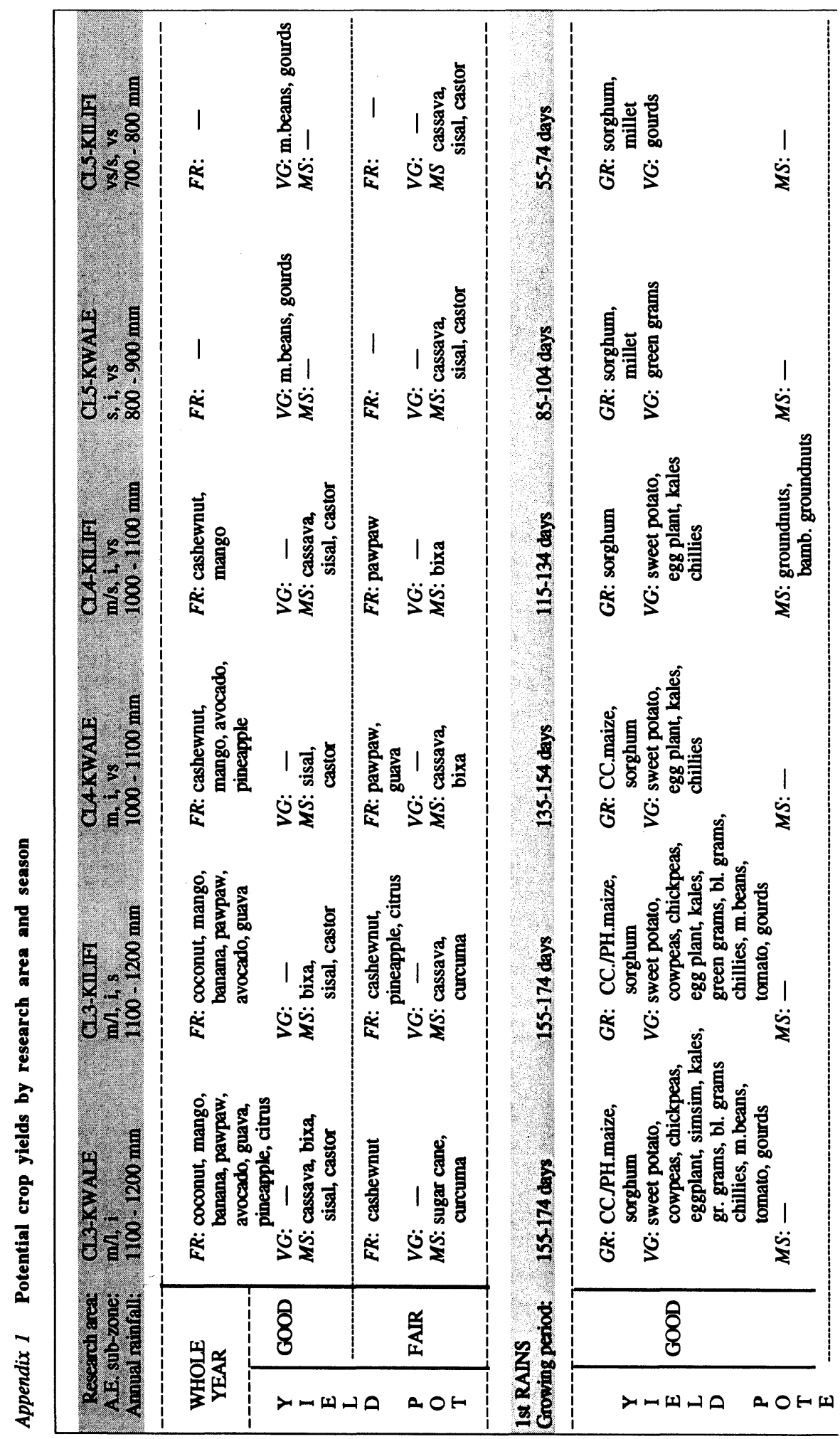




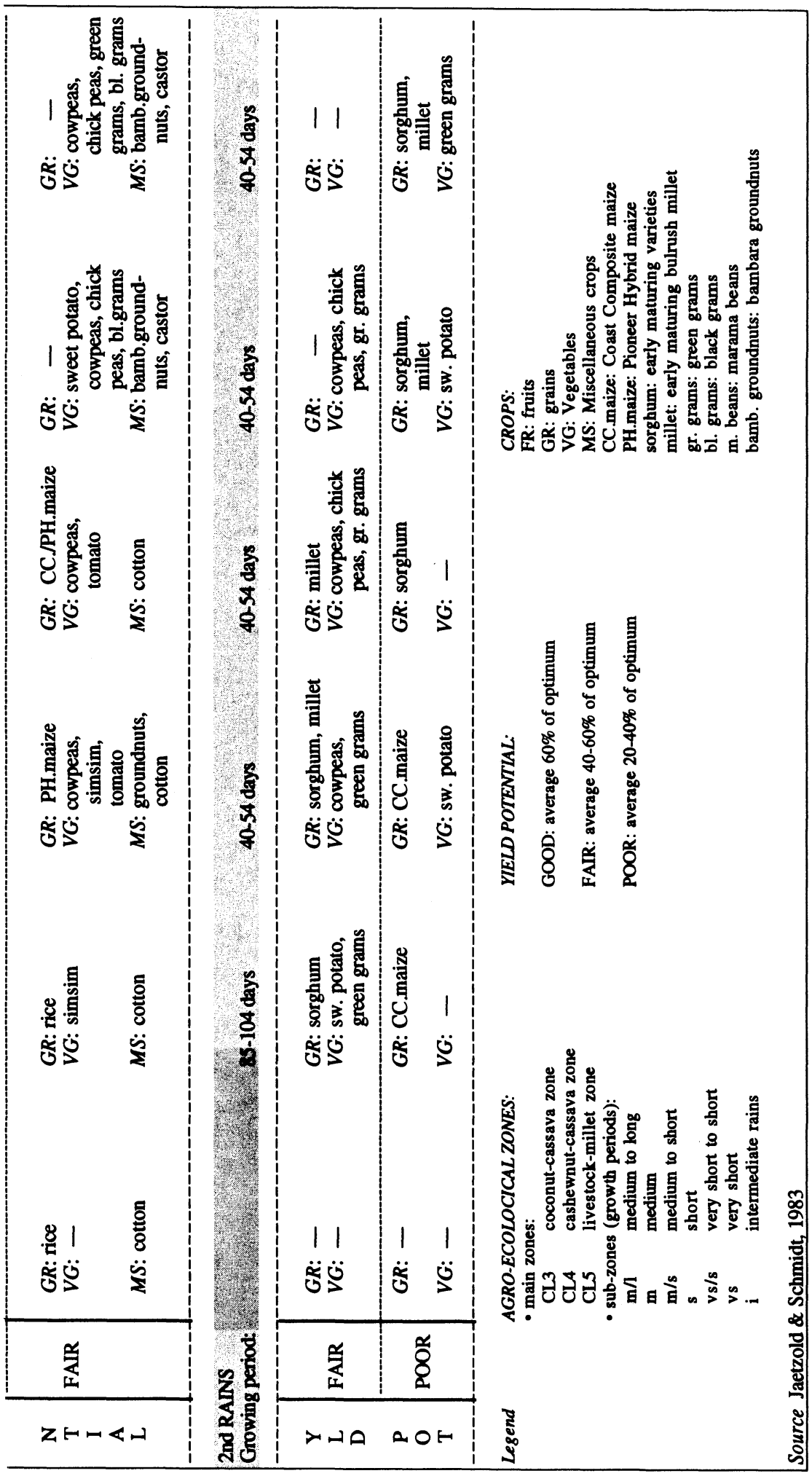




\section{Appendix 2}

\section{Research areas}

The study was carried out in two districts, Kwale and Kilifi, covering three agro-ecological zones, namely the coconut-cassava, cashewnut-cassava and livestock-millet zone. One research location was selected in each zone in each district: six research locations altogether.

\section{CL3: Coconut-cassava zone}

The CL3 area in Kwale (Bongwe) is situated about $25 \mathrm{~km}$ south of Mombasa, inland from Diani Beach, a tourist area with many hotels. By coastal standards, conditions in this area are favourable: soils are fairly fertile, there is substantial rainfall, with a dense cover of coconut palms and fruit trees. Moreover, there are employment opportunities in trade, in the nearby tourist hotels and in Mombasa which is easily reached with public transport. The local population is of Digo origin and of Islamic religion. The counterpart area in Kilifi District (Chilulu) is situated inland, in the hilly landscape near the township of Kaloleni with a mostly Chonyi population. Here also, conditions for cultivation are relatively favourable and the population density is quite high. Farmers in this area used to produce and sell considerable amounts of palm wine, until these sales were officially banned. Employment opportunities are few, Mombasa lies at about $50 \mathrm{~km}$ distance, but can be reached along a tarmac road.

\section{CL4: Cashewnut-cassava zone}

The research area in Kwale (Mwatate) is situated about $25 \mathrm{~km}$ north-west of Mombasa near the trunk road to Nairobi, a few kilometres past Mazeras. This area is less fertile and has less tree cover (mostly cashewnut trees but also batches of coconut palms). With good road connections, workers are able to commute to Mombasa, boarding matatus early in the morning and returning late in the afternoon or in the evening. The population is a mixture of the indigenous Duruma and later immigrants. The corresponding area in Kilifi District (Kitsoeni), has similar ecological conditions, with many cashewnut trees as a main characteristic but also coconuts in the higher part. This area is situated along the murram road connecting Kaloleni with Kilifi, at middle distance from the two towns. The population is mostly Kauma. Matatus, the bustling signs of economic activity, are relatively few and people have to depend on busses for transport.

\section{CL5: Livestock-millet zone}

The CL5 area in Kwale (Kibandaongo) is situated halfway along the road connecting Mazeras with Kinango. Tree vegetation is scattered and found in clusters on the rain side of hilltops. Overall, the area is dry with limited potential for crop cultivation and potential for extensive livestock rearing. The population is of Duruma origin, lives scattered, communications are difficult, distances large, while busses pass only twice a day through the area on their way to Mombasa or Kwale town respectively. The CL5 area in Kilifi (Mikamini) is even more remote. The population is mainly of Giriama origin. The landscape is less hilly than at Kibandaongo and the tree cover is even less. This is the "hinterland", where living conditions are harsh and livestock is the dominant factor in agriculture. The place is dry, windy and remote and can be reached either from Kilifi town or from Mariakani with busses that leave only twice a day. The murram roads become impassable after heavy rainfall. Employment opportunities are few and daily commution to urban centres such as Mombasa or Kilifi is not feasible. 


\section{Survey procedures}

For each research area, a map was available from the Central Bureau of Statistics* identifying about $\mathbf{1 5 0}$ households in a sub-area. The study sample consisted of every third household in the mapped area, i.e. 50 households in each area. Households without any land were excluded. This nearly always concerned people such as teachers and agricultural workers who had rented rooms/houses in the areas.

A household was defined as a group of people who reside together under a roof or under several roofs within a single compound, who are answerable to the same head and share a common source of food. In some of the research locations, this meant that the size of the household might go up to twenty, because of the prevailing extended families. In one case the total number reached forty-seven. Household members can be either resident, part-time resident or non-resident. Full-time residents are persons taking one or more meals from the household kitchen on a daily basis. Part-time residents are persons who normally live in the compound but who are or have been absent for an uninterrupted period of two weeks or more during the three months prior to the interview. Non-resident members are members of the household who are staying elsewhere for reasons of employment, education or otherwise, but who return regularly, and keep economic ties with the household.

Preparations for the fieldwork started in April 1985. The research locations were selected, the research outline was completed and the study was introduced to the local authorities. Preliminary questionnaires were drafted.

Enumerators were recruited from the respective locations with the help of the Mombasa Office of the Central Bureau of Statistics. The twelve enumerators eventually selected were young people (eleven men and one woman) between the ages of 18 and 25 years, who had completed at least four years of secondary education. The training of the enumerators took place during May 1985 and covered the necessary aspects of interviewing, recording and coding. Special attention was given to the recording of food preparation and dietary recall. Training and trial interviews were conducted at Mtwapa Farmers' Training Centre and Mtwapa Settlement Scheme as well as the home areas of the trainees. The final interview schedule was developed concurrently with the training of enumerators. A refresher training course was given before the start of the second survey round.

In order to make appointments for interviews with individual households, compounds were visited the day before the planned visit. All interviews were conducted in the local vernacular (in a few cases Swahili was used when the respondents belonged to a non-local ethnic group). Completed interview schedules were checked twice weekly by supervisors and senior staff. In order to complete missing data, compounds were revisited if necessary.

\footnotetext{
* We wish to thank the staff of the Central Bureau of Statistics who had done the actual mapping for their own survey purposes, for their permission to make use of the survey maps and the sample lists.
} 


\begin{tabular}{|c|c|c|c|c|c|c|c|c|}
\hline \multirow[t]{2}{*}{ Appendix 4} & \multicolumn{8}{|c|}{ Households and household members by residency and research area $(\mathrm{N})$} \\
\hline & Total & (\%) & $\begin{array}{c}\text { Kwale } \\
\text { CL3 }\end{array}$ & $\begin{array}{c}\text { Kilifi } \\
C L 3\end{array}$ & $\begin{array}{c}\text { Kwale } \\
\text { CL4 }\end{array}$ & $\begin{array}{c}\text { Kilifi } \\
\text { CL4 }\end{array}$ & $\begin{array}{c}\text { Kwale } \\
\text { CL5 }\end{array}$ & $\begin{array}{c}\text { Kilifi } \\
\text { CL5 }\end{array}$ \\
\hline Households & 297 & & 50 & 50 & 48 & 50 & 49 & 50 \\
\hline full-time residents & 2314 & (87) & 279 & 458 & 289 & 375 & 331 & 582 \\
\hline part-time residents & 107 & $\begin{array}{l}\text { (4) } \\
\text { (4) }\end{array}$ & 9 & $\begin{array}{r}450 \\
8\end{array}$ & 11 & 2 & 10 & 67 \\
\hline non-residents & 229 & (9) & 11 & 71 & 21 & 54 & 23 & 49 \\
\hline total & $=2650$ & (100) & $=299$ & $=537$ & $=321$ & $=431$ & $=364$ & $=698$ \\
\hline
\end{tabular}

\begin{tabular}{|c|c|c|c|c|c|c|c|c|}
\hline \multirow[t]{2}{*}{ Appendix 5} & \multicolumn{8}{|c|}{ Full-time residents by age group and research area $(\mathrm{N})$} \\
\hline & Total & $(\%)$ & $\begin{array}{c}\text { Kwale } \\
\text { CL3 }\end{array}$ & $\begin{array}{c}\text { Kilifi } \\
\text { CL3 }\end{array}$ & $\begin{array}{c}\text { Kwale } \\
\text { CL4 }\end{array}$ & $\begin{array}{c}\text { Kilifi } \\
\text { CL4 }\end{array}$ & $\begin{array}{c}\text { Kwale } \\
\text { CL5 }\end{array}$ & $\begin{array}{c}\text { Kilifi } \\
\text { CL5 }\end{array}$ \\
\hline $00-09$ years & 871 & (38) & 92 & 181 & 110 & 146 & 134 & 208 \\
\hline $10-19$ years & 565 & (24) & 64 & 116 & 65 & 93 & 65 & 162 \\
\hline $20-29$ years & 306 & (13) & 46 & 48 & 38 & 45 & 53 & 76 \\
\hline $30-39$ years & 241 & (10) & 33 & 45 & 37 & 27 & 41 & 58 \\
\hline $40-59$ years & 237 & (10) & 38 & 47 & 24 & 46 & 29 & 53 \\
\hline $60+$ years & 94 & (4) & 6 & 21 & 15 & 18 & 9 & 25 \\
\hline total & $=2314$ & (100) & $=279$ & $=458$ & $=289$ & $=375$ & $=331$ & $=582$ \\
\hline
\end{tabular}

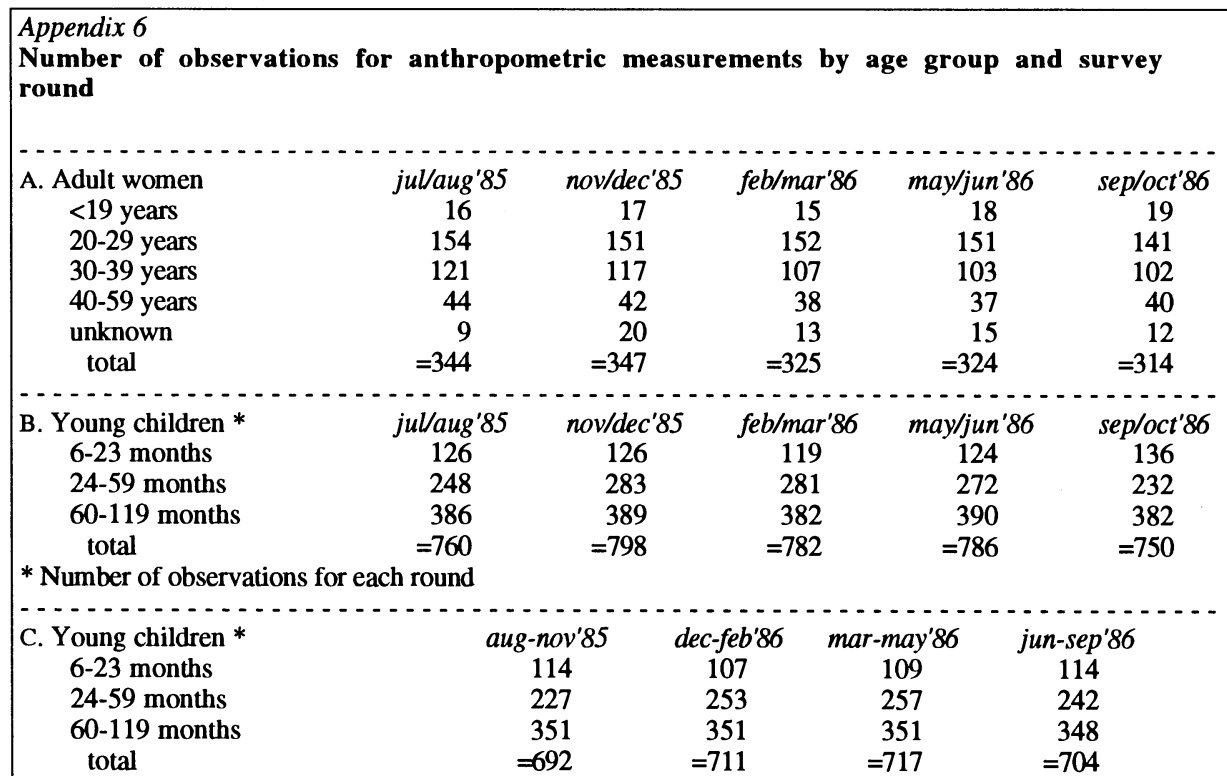

* Number of children with observations in two subsequent rounds (needed to calculate growth velocities) 


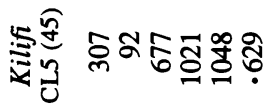

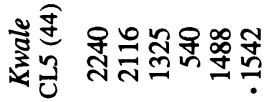

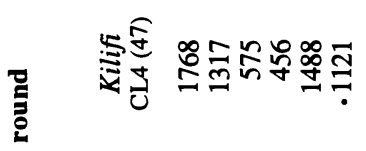

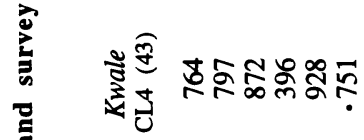

.

a

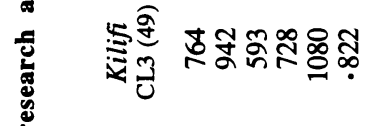

2

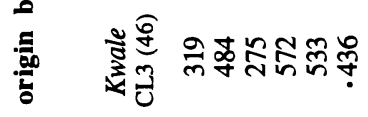

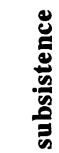

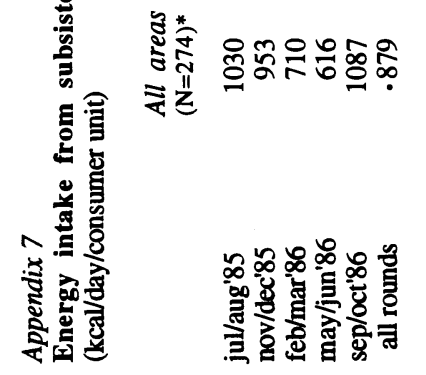

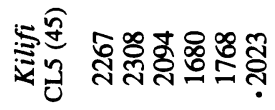

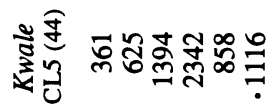

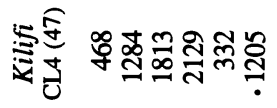

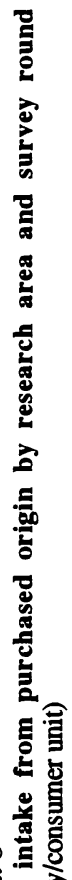

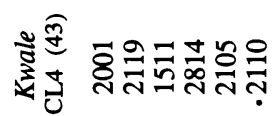

홀

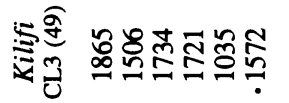

岂

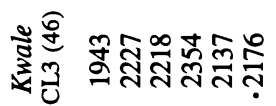

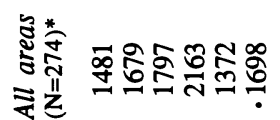

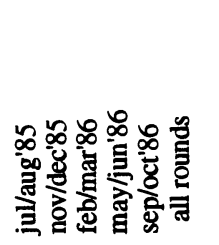



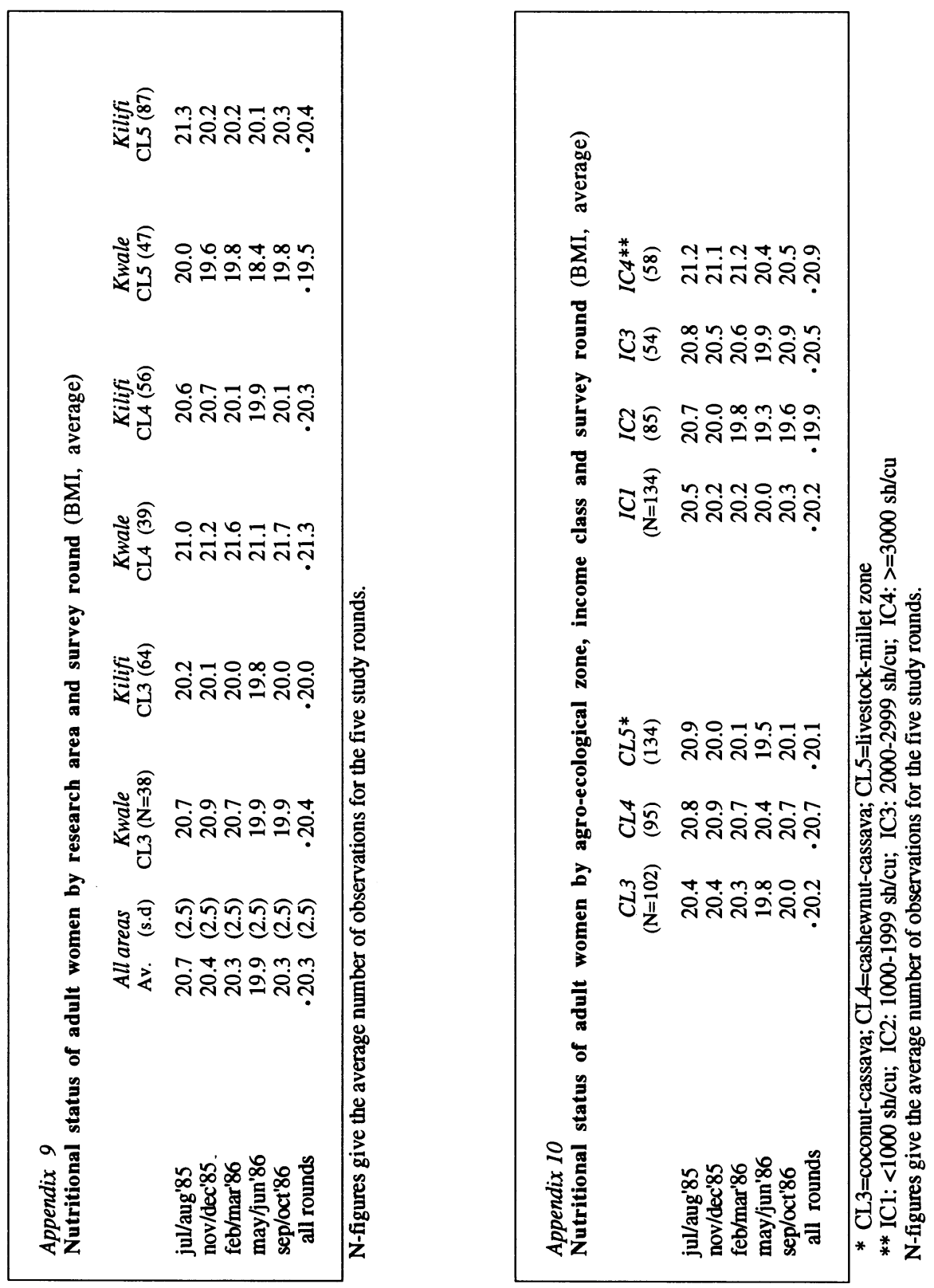


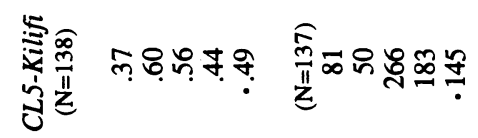

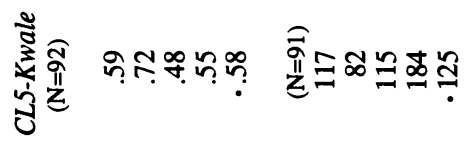

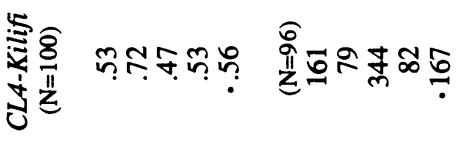

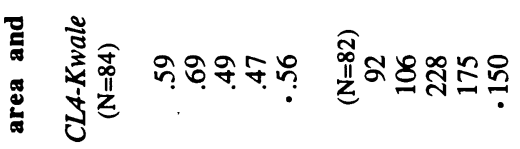

돈

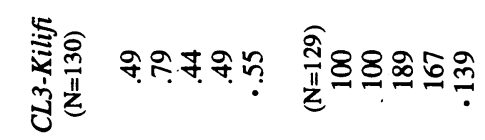

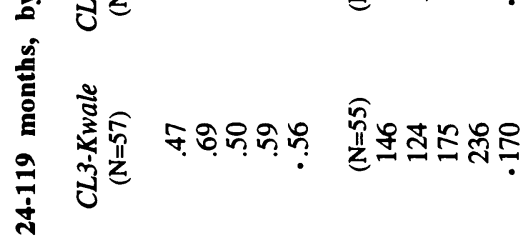

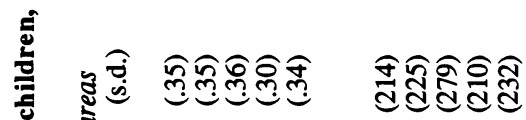

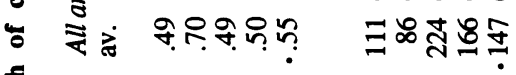

竞

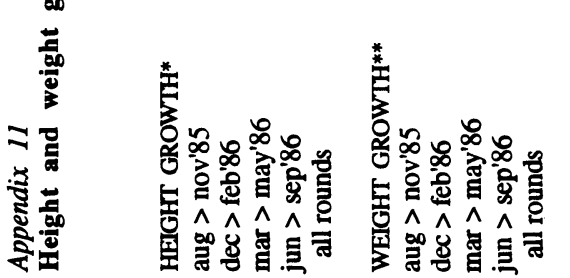

量 

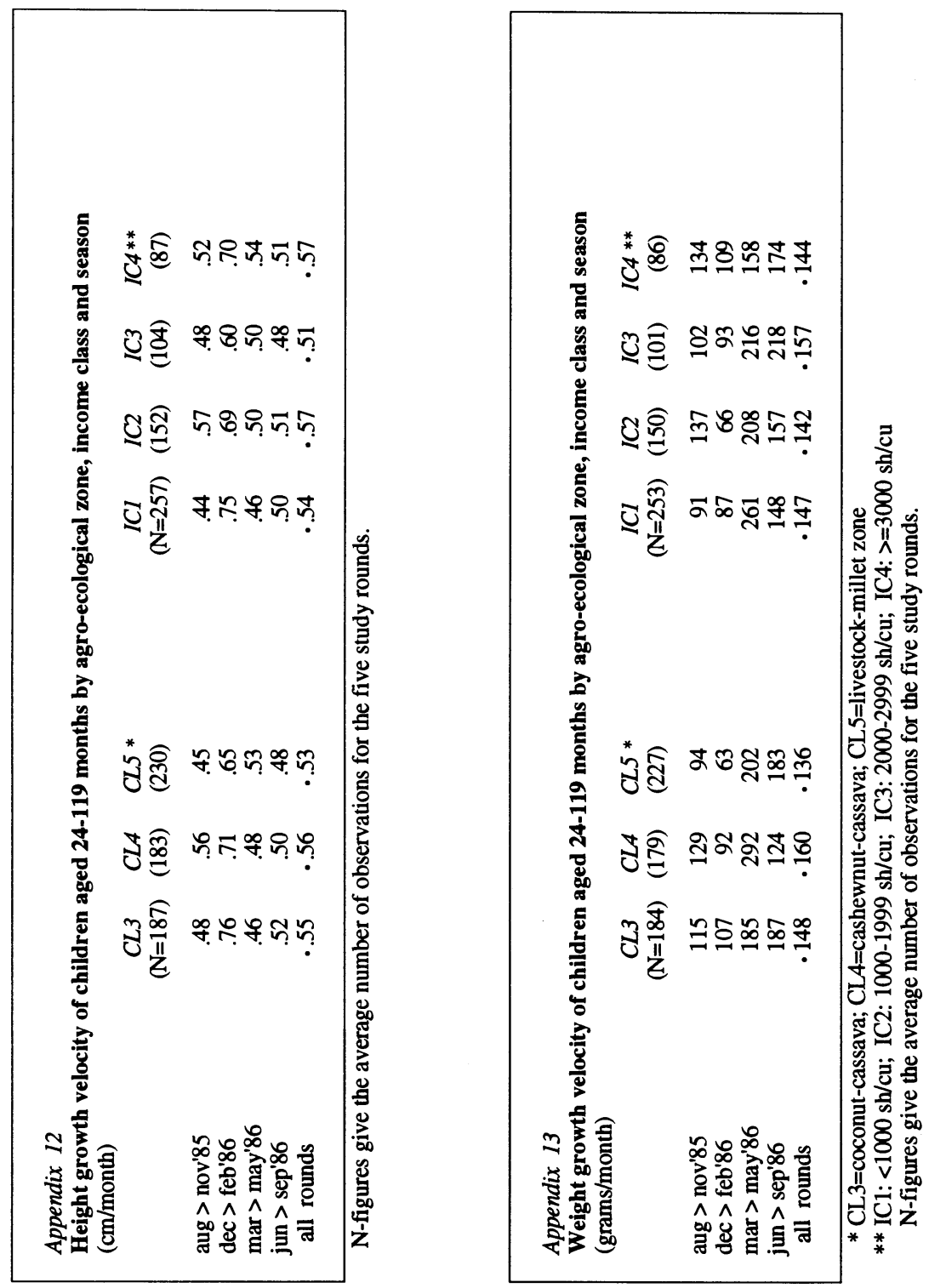
Notes 


\section{Chapter 2}

1 See Chambers, Longhurst \& Pacey 1981; AMREF 1982; Longhurst 1986a; Garine \& Harrison 1988a; Sahn 1989; Foeken \& Hartog 1990.

2 Besides climate-induced seasonal patterns, other annual cycles also influence life in local communities. Perhaps the most well-known example is the great annual fast of the Islamic calendar, Ramadan. When Ramadan coincides with the peak in agricultural labour, this may influence labour supply and, consequently, production (Gill 1991). External interventions, such as the policies of national governments or the activities of non-governmental organisations, have their own rhythms, too; rhythms that may coincide or collide with the dimensions of the climatic seasonal pattern. Examples are the fluctuations in government spending (i.e., the financial year of the government) and the school calendar (Dietz 1990).

3 People often sow or plant on the same fields as used during the long rains, so that no land clearing has to be done. Also, because of the smaller amount of rainfall there is less weeding to be done.

4 See Bradley 1981; Chambers et al. 1979; Rowland et al. 1981; White 1986.

5 Waddy (1981) gives the example of cerebrospinal meningitis (CSM) in north-west Ghana. CSM is an epidemic disease caused by an organism which spreads via the respiratory route. The organism concerned (meningococcus) can survive for only very little time in moist air and is killed by ultraviolet light. CSM is therefore spread during the dry season, from one person to another in dark, interior conditions. In former times people had no blankets, and in the cold nights of the dry season, they slept close together to keep warm. A slight rise in the level of living, however, reduced the incidence of CSM considerably. The development of a money economy, just enough to enable a man to buy blankets to keep his family warm at night, was enough to demote CSM from its former status.

6 See Messer 1989; Apeldoorn 1981; Longhurst 1986b; Jiggins 1986; Dietz 1987.

7 An informative study on coping mechanisms in Kenya is that by Dietz (1987) on the semi-arid district of West-Pokot. The Pokot traditionally lived a pastoralist way of life, many of them are cultivators as well and they avail of a wide range of adaptations to crisis situations. Although the study focuses on periods of sustained dryness and not on seasonal food shortages, many of the mechanisms described by the author can be found among the seasonal measures described in the present text.

8 Different kinds of adaptation exist in the demographic and in the magical sphere.

In societies where food supply varies widely and where acute food shortages may occur any year, it is important to keep human populations small. ".....there is evidence that African nomadic pastoralists in general have low rates of natural increase compared to neighbouring farming people, and that these are due to low birth and death rates (...). These differences (...) seem to be the result of social regulation of the demographic processes. (...) in various African pastoral societies, such practices as generation grading coupled with a ban on child bearing in the junior grades, late marriages, and post-natal sexual abstinence are found. There is suggestion that Somali-pastoralists practice sexual abstinence during the dry season and in drought years" (Swift 1981, 85). Evidently, such brakes on population growth may keep population size low in relation to resources, and could ease conditions at the time of the lean season.

Garine \& Koppert (1988) describe magical practices related to the soil and the crops growing in it. Another example comes from the Kenya Coast. In describing soil management practices, Oosten (1989) notes that "Not all farmers see the application of manure or fertilizer as a necessity for soil conservation. According to Mijikenda traditions, there are other methods to guarantee soil fertility and to protect the fields against theft, witchcraft, evil eye, diseases and pests. Such methods are, for example, the burying of certain medicines (plants and roots) in the soil, or the placing of a magic stick in one of the corners of the field. Such a custom, executed by a local medicine man, is believed to be more effective than the application of manure or fertilizer." 
9 There are also other constraints, however, since compared to men, women are usually less educated, possess less bargaining power, have less access to resources, fewer contacts with bureaucrats, as well as more restricted access to credit and training facilities. See Tellegen 1993.

10 See Reardon, Matlon \& Delgado 1988; Reardon \& Matlon 1989; Matlon \& Kristjanson n.d.

\section{Chapter 3}

11 See Beinum et al. 1985; Carlsen 1980; Floor 1981; Jaetzold \& Schmidt 1983; Schreurs 1982; Waaijenberg \& Salim 1983; Waaijenberg 1994.

12 At the time, the total cattle population in Kilifi District was estimated at about 213,000 head, of which 13,000 of improved breeds (MOA 1986).

\section{Chapter 4}

13 For the analysis of survey findings at household level, it is important to standardize household size. The most common way is a straight count of the number of household members, which means that each member receives an equal weight. For certain (e.g. demographic) purposes, this is quite appropriate.

For other purposes, however, a weighted summation is needed because the requirements of household members differ from each other. For example, the food consumption of a child is less than that of an adult, but this is also true for other needs: shelter, clothing, transport, etc. An approximation of the relative needs is offered by a physiological weighting, namely according to the nutritional requirements of individual household members. This incorporates various biological characteristics: age, sex, physiological status and physical activity level and it offers a fair approximation of overall requirements, also because food consumption forms a large part of overall consumption.

Weighting in this way is known by the term 'consumer units'. One consumer unit (cu) is equal to a reference adult male. The reference adult male of 20-29 years of age is estimated to need $2960 \mathrm{kcal}$ per day. All other individuals are expressed as a ratio of this unit (adult male equivalents) on the basis of their estimated nutritional requirements. For the calculation of these requirements the international recommendations were used (WHO/FAO 1985). Further assumptions that were made in order to fit the reference standards to the circumstances in Coast Province concerned body size, pregnancy and lactation, activity patterns and disease. The energy requirements of the various age and sex groups, expressed in terms of consumer units, are as follows:

$\begin{array}{ccccccccc}\text { age } & \text { male } & \text { female } & \text { age } & \text { male } & \text { female } & \text { age } & \text { male } & \text { female } \\ 0 \mathrm{yr} & 0.3 \mathrm{cu} & 0.3 \mathrm{cu} & 8-10 \mathrm{yr} & 0.7 \mathrm{cu} & 0.7 \mathrm{cu} & 30-39 \mathrm{yr} & 1.0 \mathrm{cu} & 0.8 \mathrm{cu} \\ 1 \mathrm{yr} & 0.4 \mathrm{cu} & 0.4 \mathrm{cu} & 11-16 \mathrm{yr} & 0.8 \mathrm{cu} & 0.7 \mathrm{cu} & 40-59 \mathrm{yr} & 0.9 \mathrm{cu} & 0.7 \mathrm{cu} \\ 2-4 \mathrm{yr} & 0.5 \mathrm{cu} & 0.5 \mathrm{cu} & 17-19 \mathrm{yr} & 0.9 \mathrm{cu} & 0.7 \mathrm{cu} & 60 \mathrm{yr}+ & 0.7 \mathrm{cu} & 0.6 \mathrm{cu} \\ 5-7 \mathrm{yr} & 0.6 \mathrm{cu} & 0.6 \mathrm{cu} & 20-29 \mathrm{yr} & 1.0 \mathrm{cu} & 0.8 \mathrm{cu} & & & \end{array}$

14 Production of annual crops, tree crops and perennials was assessed by means of interviews. The acreage planted or the number of plants were recorded together with the quantities harvested and crop sales during the period under review. Herd composition and livestock turn-over were similarly recorded, notably the number of poultry, goats, sheep and cattle that were added or deleted from the existing herd; together with estimates of milk and egg production and milk sales. Further items concerned crop cultivation practices and livestock management.

15 Some of the results are presented in the forms of ratios, such as the number of rooms/ house, the child/adult ratio and various indicators per consumer unit. There are two possible ways of calculating these ratios: a) by calculating the ratio for each household (e.g. rooms/house) and subsequently calculating the average of the ratio over all households; and b) by separately summing the two individual factors in the ratio over all households, subsequently dividing the totals on each other. The two methods can give quite different 
results for the same data set. The discrepancy between the two methods tends to be larger when the factor used as the divisor in the ratio has a large standard deviation.

In this monograph the first method has mostly been used since we are primarily concerned with characteristics of the average household. The second method was used, however, in the case of certain agro-ecological factors and is indicated in the tables as area ratio.

16 Under the definitions used in this survey households or part-households cultivating and living elsewhere were not considered part of the sample. A few households reported ownership of holdings elsewhere, notably in the settlement schemes in the coastal strip, which explains some slight anomalies in the data later on (for example, the recorded presence of certain types of trees in unsuitable areas such as Mikamini).

17 For purposes of calculating the available farm labour, each adult, aged 17-60 years and full-time resident, was counted as one farm labour equivalent. Children, aged 11-16 years and not schooling, were counted as 0.5 equivalent; elderly people over 60 years also counted as 0.5 equivalent. Persons with off-farm employment were not counted, unless not employed full-time, in which case they were counted partly as farm labour. The period concerned was mid-1985 to mid-1986.

Since this calculation also includes people and time ordinarily devoted to domestic and social activities, the figures necessarily give overestimates of actual labour input in agriculture and as such underestimates of the returns for agricultural labour.

18 Meteorological data were available for Kilifi District (Meteorological Department, Nairobi, and MOA 1986). According to Oosten $(1989,49 ; 72)$, the situation in Kwale was about the same. In Kibandaongo (CL5), "both the long rains and the short rains of 1985 were below average", while in Bongwe (CL3), "both the long rains and the short rains of 1985 have been regarded by seven households as enough and by eight households as too little for a reasonable harvest". This might indicate that in 1985 the rainfall situation in the coastal belt was better than in the hinterland, if compared with 'normal' years.

19 The level of food self-sufficiency was calculated for households on the basis of the following foodcrops: cereals, beans, cassava and bananas (in the case of CL3-Kwale, bananas were counted partly because in that area they are also sold as a cash crop).

For each of these crops, the total yield of the harvests of the long rains of 1985 and the short rains of 1985/86 (in $\mathrm{kg}$ ) was estimated and multiplied by a certain percentage in order to obtain the net yield, i.e. the edible portion $(90,100,85$ and 67 per cent for cereals, beans, cassava and bananas, respectively).

These figures were multiplied with the respective caloric values per kilogram (3400 for cereals and beans, 1530 for cassava and 1100 for bananas) and added. For each household, this figure was divided by the average number of consumer units, thus obtaining the annual staple food production (in kcal) per consumer unit.

Energy requirements per consumer unit were estimated to be $2960 \mathrm{kcal}$ per day, and it was assumed that $75 \%$ of this amount is generally provided by staple foods, i.e. 2220 kcal. per day or 810,300 kcal. per consumer unit per year (This assumption was later corroborated by the actual results. The contribution of the staple foods equalled 2166 $\mathrm{kcal}$, being $84 \%$ of the actual intake and $73 \%$ of the estimated requirements).

The degree of food self-sufficiency was calculated by expressing the annual food production/cu as a percentage of the staple energy requirements.

20 As regards cassava, the food self-sufficiency calculations are not based on the number of plants harvested but on the number of plants reportedly cultivated. It was assumed that cassava plants have a growth period of 15.3 months and that, on average, they produce a harvested weight of $1 \mathrm{~kg}$. This weight is much lower than the potential weight of an individual plant cultivated and harvested under optimal conditions. Usually, however, only a fraction of the cassava planted will be used for own consumption, thus reducing the average (harvested) weight per plant as counted in the field. It has already been mentioned that crop yields further suffer as a result of infections by the mosaic virus. Cassava is 
often used as a reserve food, and when food shortages do occur, the crop will often be harvested before being fully mature. Usually this is not the case and the remainder of the crop may be left in the fields or sold for factory processing. The latter is done at a later stage and at a much lower price than the cereal equivalent prices used in this report. When alternative calculations are made in which the estimated weight per cassava plant is doubled $-2 \mathrm{~kg}$ - the degree of food self-sufficiency still remains below 60 per cent (see figures below):

$\begin{array}{lccccccc} & \text { Total } & \text { CL3-Kwale } & \text { CL3-Kilifi } & \text { CL4-Kwale } & \text { CL4-Kilifi } & \text { CL5-Kwale } & \text { CL5-Kilifi } \\ \text { food self-suffy. } & 57 \% & 61 \% & 42 \% & 54 \% & 89 \% & 81 \% & 15 \% \\ \text { h.holds < } 50 \% & 58 \% & 52 \% & 70 \% & 52 \% & 46 \% & 31 \% & 96 \%\end{array}$

More than half the households remain unable to provide half of the household energy requirement. The overall trends for the areas also remain the same, except for CL3-Kwale where farmers have large numbers of cassava plants in the fields. Data on the actual contribution of cassava to daily food consumption are presented in Chapter 5.

21 The value of the food crop production was estimated by using a price of sh.4/- for one $\mathrm{kg}$ of harvested cereals (consumer price), cassava and bananas for home consumption (converted into cereal equivalents according to caloric values), and sh.8/- for one $\mathrm{kg}$ of harvested beans.

The value of the cash crop production was determined by estimating the monetary income from the sales of the produce of trees with a commercial value (in the case of CL3Kwale commercial bananas were also included).

The value of livestock rearing consists of two elements: a) the income from the sales of poultry and milk (the latter was corrected for "caretaker", in the sense that it concerned only milk from cattle that was taken care of by one of the household members or by hired labour); and b) the increase of the value of cattle and goats/sheep through reproduction.

In the case of two variables a maximum value was determined to prevent serious distortions in the mean values: sh.3,200/cu for the value of annual food crops (cereals and beans); and sh.2,000/cu for tree crops.

22 Other sources confirm this high figure. The Agricultural Production Survey of 1986/87 reported that in Kwale and Kilifi only 60-65 per cent of farm-holders were resident on their holdings; the lowest figures for all districts in Kenya and comparing with a national average of nearly 90 per cent resident farm-holders (CBS 1989).

23 Information was collected on three types of casual labour: casual labour in town, casual labour at estates/plantations and local casual labour in the rural areas. In the earlier reports the income of the latter kind was analysed separately but in this monograph is included under casual labour.

24 In the case of full-time residents the total wage salary was included in the household income; in the case of part-time residents 75 per cent of the salaries was included; and for non-residents 25 per cent of the salary.

25 This is higher than the returns for labour in agriculture by more than a factor 4 (p. 60). Such a comparison, however, is deceptive for the reasons explained in note 17 above, nevertheless it is safe to say that sizeable differences exist.

26 The exchange rate for the Kenya shilling in 1985 was 1 US $\$=16 \mathrm{sh}$.

27 CBS (1988) carried out the Rural Household Budget Survey in 1981/82 and reported average monthly incomes (cash and kind) of sh.937/household in Kwale and sh.663/ household in Kilifi/Tana River/Lamu. Aggregated, this amounts to a household income of sh.800/month or sh.9,600/year. This compares with our estimate of sh.10,025/year. The two figures are conveniently close but leave the rate of inflation unaccounted for and also overlook differences in research methodology.

The average rate of inflation for the 4 years between 1981/82 and 1985/86 can be estimated at 14 per cent annually, on the basis of the Nairobi consumer prices index. The 
CBS reported income for $1981 / 82$ recalculated at $1985 / 86$ prices therefore amounts to sh.16,128/year $(1.68 * 9,600)$.

A second correction is necessary because in the present survey the incomes of wage earners were corrected for residency (note 24), something which was not done for the CBS survey. If the total wages of all off-farm employment, recorded during the present survey, are included unweighted in the household incomes, the average household income increases to sh. $15,727 / y e a r$. This is within $2 \%$ of the above CBS figure, corrected for inflation.

CBS (1988) reported that household incomes in Kilifi are lower than in Kwale District. When the present survey results are aggregated by district household incomes are higher in Kilifi District. However, closer inspection reveals that this is the result of the larger household size in Kilifi particularly by the high household incomes in CL5-Kilifi which has an extremely large household size. Otherwise, household incomes in the CL3 and CL4 areas in Kilifi were below those in the corresponding Kwale areas. When corrected for household size, the income per consumer unit shows the opposite effect namely that it is higher in Kwale District: sh.2155/cu vs. 1670/cu. As a consequence the percentage of households below the food poverty line is larger in Kilifi than in Kwale District, namely 45 vs. 28 per cent.

28 The Food Poverty Line was defined as the annual household income needed to purchase the amount of calories required to meet the minimum nutritional needs of household members and was calculated at sh.990/cu (rounded at sh.1,000/cu). The calculation method used is derived from that of the Fifth World Food Survey (FAO 1987).

The minumum nutritional needs are defined as the need at minimal bodily function at minimum body weight. Minimum body weight was pegged at $54.3 \mathrm{~kg}(=90$ per cent of average weight). The basic metabolic rate corresponding with this weight is 1510 calories, multiplied by a factor 1.4 to allow for mimimal activities (not including exercise or work), results in an estimate of $2115 \mathrm{kcal} / \mathrm{cu} / \mathrm{day}$ or $772,000 \mathrm{kcal} / \mathrm{cu} / \mathrm{year}$.

Assuming a food package that consists for 75 per cent of cereals (at sh.4/kg) and for 25 per cent of other foods (at sh.6/kg) and a caloric value of $3,500 \mathrm{kcal} / \mathrm{kg}$ results in an estimated cost of sh.990/cu $(772,000 / 3,500 * 4.5)$.

In an analysis of data from the Integrated Rural Survey of 1974/75, using slightly higher caloric requirements $(2250 \mathrm{kcal} /$ adult-equivalent) but based on data from only 64 households, the Food Poverty Line in Coast Province was calculated at sh.331/adult-equivalent (Greer \& Thorbecke 1986, 39). The average inflation rate for the decade 1976-1985 can be estimated at 12.5 pert cent annually, on the basis of the Nairobi consumer price index. Recalculated at 1985/86 prices this results in a figure of sh.1,070/adult-equivalent for the earlier CBS-survey, which compares with a figure of sh.990/cu used in the present survey. The Food Poverty Line is a quite different concept from that of food self-sufficiency explained in note 19 above. Food self-sufficiency refers to the food production of a household in terms of staple foods (which are assumed to account for 75 per cent of the recommended daily intake needed for a normal healthy and active existence, $2960 \mathrm{kcal}$ ). The Food Poverty Line refers to the 'purchasing power' of a household necessary to assure a minimum energy supply for daily survival with minimum activity (calculated at $2115 \mathrm{kcal} /$ day).

29 Further analysis gave no indication that households with wage incomes do invest in farming in order to realize higher farm production. The value of cash crops and livestock did not increase consistently with wage income (Table 50). Neither did food crop production show a consistent increase with wage income. In fact, groups with similar wage income levels showed quite different farm incomes, which indicates the presence of households with quite different household economies at similar income levels. 
Table 50 Value of Agricultural Production by Wage Income

$\begin{array}{lcccc}\text { wage class } & N & \text { wage income } & \text { food crops } & \text { cash crops \& livestock } \\ -499 & 132 & 115 & 522 & 198 \\ 500-999 & 43 & 704 & 461 & 182 \\ 1000-1499 & 28 & 1195 & 577 & 455 \\ 1500-2499 & 36 & 1956 & 351 & 336 \\ 2500-3499 & 32 & 2954 & 481 & 230 \\ 3500+ & 26 & 5032 & 439 & 249\end{array}$

(all figures, except $\mathrm{N}$, in $\mathrm{sh} / \mathrm{cu}$ )

\section{Chapter 5}

30 In 1986, Ramadan was from May 10 until June 9, i.e. during the fourth survey round. In CL3-Kwale, the only Muslim area, the energy intake from home-produced food was high during that round. There was no evidence of a lower energy intake that could negatively influence available agricultural labour.

31 Food consumption was assessed by a recall of all food prepared in the compound during the day prior to the interview. The recall of food preparation was collected for each kitchen of the household. The women concerned were questioned about all the foods and drinks they had prepared in the course of the previous day. Starting with the first dish of the day, all subsequent dishes (drinks and snacks) were covered. The women were further asked to demonstrate the cooking procedures, and to indicate the volumes of the different ingredients used, as well as the total volume of the dish as finally prepared. In case of leftovers from meals, the volume of food that had not been eaten was separately estimated and subtracted. For each ingredient it was further noted whether it was home-produced or not.

In some households visitors participated in meals, in other households some members had meals while visiting a friend or relatives. A check on a subsample of households revealed no systematic bias from this source: visitors and outside meals canceled each other out statistically.

32 There exist a few studies that have compared the nutritional conditions of groups of smallholders with different economic characteristics e.g. rice growers, sugar growers, agricultural labourers. These studies usually include a comparison group of peasant smallholders who do not participate in such economic activities or agricultural projects, whatever the case. These studies are remarkably consistent in the level of energy intake they report for peasant smallholders namely $2670 \mathrm{kcal}$ in South Nyanza District (Kennedy 1994); $2590 \mathrm{kcal}$ in Kisumu District (Niemeijer \& Hoorweg 1994); $2581 \mathrm{kcal}$ in Trans Nzoia District (Foeken \& Tellegen 1994).

33 See WHO/FAO $(1985,133)$. A requirement of $2960 \mathrm{kcal}$ per consumer unit corresponds with about $2100 \mathrm{kcal}$ per capita.

34 The figures in Table 27 (p. 70) and Table 30 (p. 72) do not reflect the percentage of households with a continuously low energy respectively protein intake, as the data are based on a one-day 'snapshot' per household in each season. The prevalence of households with a more or less continuously low energy intake is bound to be somewhat less, depending on the extent of day-to-day variation in intake.

35 The safe level of protein intake was calculated according to the proposed procedure by WHO/FAO (1985, Table 55). The procedure is to derive first an average protein requirement and then to add a margin for statistical uncertainty (conventionally: +2 standard deviations). While the coefficient of variation (CV) of individual protein requirements is estimated to be $12.5 \%$, the CV for aggregate household requirement is much less, as summing up of individual variances gives a lower overall variance. On the basis of a model household with about 6 consumer units, a CV of aggregate household protein requirement of about $4.5 \%$ can be derived. 
One consumer unit corresponds to an energy intake of $2960 \mathrm{kcal}$ (for a nominal adult male). The same male necds on average $0.6 \mathrm{~g}$ reference (ideal) protein per $\mathrm{kg}$ body weight. Assuming a protein digestibility of $88 \%$, his average requirement in terms of dietary protein (body weight: $60.3 \mathrm{~kg}$ ) would be $41.4 \mathrm{~g}(5.55 \%$ of the energy). His individual 'safe level' of protein would be that amount plus 2 times the CV of $12.5 \%$ (see above), that is $51.4 \mathrm{~g}$, which represents $6.94 \%$ of the energy. However, members of the vulnerable groups (children below 3, adolescents, women and the elderly) have relatively higher protein requirements within a given amount of energy; besides, children and adolescents have relatively high requirements of the essential amino acids, so that their requirements have to be corrected upwards to account for protein quality.

Therefore, an average requirement of dietary protein of $6 \%$ of the energy has been chosen here (this corresponds to a 'safe level' of $7.5 \%$ on an individual basis). The safe amount per consumer unit (supposing ideal distribution among individuals) becomes then $6 \%$ of $2960 \mathrm{kcal}$, that is $44.4 \mathrm{~g}$ dietary protein, plus two times the CV of $4.5 \%$, that makes a 'safe household level per consumer unit' of $48.4 \mathrm{~g}$ dietary protein. This figure has been rounded to $50 \mathrm{~g}$. which is an aggregate household value not taking account of possible unequal distribution within the household.

36 In Chapter 4 (p. 57), an independent calculation based on food production figures estimated the degree of food self-sufficiency to be 45 per cent of the energy usually supplied by cereals or $34 \%$ of the total energy intake $(.45 * 75$; see note 19$)$. This corresponds very well with the observed energy intake from home production of about 35 per cent of the total energy intake.

37 The traditional gifts of food are now largely obsolete. 'Food from the wild' by means of hunting, fishing and gathering also plays little role in Mijikenda food supply. Large animals can no longer be hunted, partly because they are not present anymore, partly because it is illegal. In as far as wild animals are eaten nowadays, it is restricted to small rodents, birds and grasshoppers (Waaijenberg 1994). Gathering of wild plants still takes place, but although several of these are eaten, their contribution to the daily diet is very marginal indeed.

38 From Table 34 (p. 75) it can be calculated that the energy intake in the households in Kwale District is, on average, about $250 \mathrm{kcal} / \mathrm{cu}$ higher than in Kilifi District. This difference between the districts is probably caused by two interrelated factors, firstly, the difference in household income mentioned in note 27 and, secondly, the existing difference in household size. The household size in Kwale District is 4.6, in Kilifi District it is 7.0 consumer units (p. 51). In large households greater amounts of food have to be prepared but a recurrent (though so far unexplained) finding is that the amounts per person tend to be less in larger households. Consequently, there is a negative relationship between household size on the one hand and energy intake on the other. This effect was earlier reported by Greer $\&$ Thorbecke (1986). In the present survey, regression calculations give a lower energy intake of $73 \mathrm{kcal} / \mathrm{cu}$ for each increase in household size with one consumer unit (Niemeijer et al. 1991, 35). The difference in household size between the districts is 2.4 consumer units and this accounts for almost $200 \mathrm{kcal} / \mathrm{cu}$ or most of the difference of 250 $\mathrm{kcal} / \mathrm{cu}$ that was found to exist between the districts.

39 The energy composition in terms of food groups is quite similar in the different research areas with minor exceptions. Cereals contribute the major share to energy intake in all areas but in the two CL3 areas starchy roots contribute 12 per cent because of higher cassava consumption. In the CL3-Kwale area the consumption of animal products and miscellaneous items further contribute about 10 per cent and this must be because of the fact that food purchases are high and there are opportunities for buying all kinds of foods in this bustling area; opportunities which are not present, for example, in the CL5-Kilifi area which also has high food purchases but which mostly consists of maize.

40 Other possible measures that can be used are the standard deviation, the variance and the coefficient of variation. These measures, however, give extra weight to extreme deviations 
by squaring of values to accentuate error variance. Since the present interest is in the seasonal variations that naturally occur (not by error) there is less reason to give extra weight to large deviations.

41 During May/June the energy intake from home-grown cassava in the six research areas was as follows: CL3-Kwale (363 kcal/cu); CL3-Kilifi (444 kcal/cu); CL4-Kwale (161 $\mathrm{kcal} / \mathrm{cu})$; CL4-Kilifi (29 kcal/cu); CL5-Kwale (97 kcal/cu); CL5-Kilifi $(9 \mathrm{kcal} / \mathrm{cu})$.

\section{Chapter 6}

42 For example, when height-for-age stays behind improvements in weight-for-height are difficult to interpret. In the case that height and weight do not grow evenly together there will occur increases in one indicator and decreases in the other indicator which are nevertheless of little meaning.

43 A further analysis of the seasonal changes in height-for-age and weight-for-height was attempted in Niemeijer \& Klaver (1990) with particular attention for the effects of agroecological zone.

44 Beaton \& Ghassemy (1983) in their overview study on preschool supplementary feeding centres tried to evaluate the anthropometric response to increased food intake. In their calculations, they evaluate the theoretical energy cost of growth as follows: (i) $5 \mathrm{kcal}$ per gram of body mass deposited and (ii) around $55 \mathrm{kcal}$ per $\mathrm{kg}$ per day for the increase in basal metabolic rate (BMR) and maintenance requirements. For the latter component, one may also refer to the equations provided by WHO (1983). For children aged 0-3 years, BMR in kcal per day is estimated at $60.9 * \mathrm{~W}-54$ (boys) or $61.0 * \mathrm{~W}-51$ (girls), where $\mathrm{W}=$ body weight in $\mathrm{kg}$; this means about $61 \mathrm{kcal}$ per incremental $\mathrm{kg}$. For a hypothetical child that grows $1 \mathrm{~kg}$ in a year ( $3 \mathrm{~g}$ per day), this means $15 \mathrm{kcal}$ per day for laying down new tissue and on average $30 \mathrm{kcal}$ per day for increased maintenance requirements, an average of about $45 \mathrm{kcal} / \mathrm{day}$.

From the review of supplementary feeding programmes, it appeared that increased food intake did not fully translate in increased growth. On the whole (representative data), about 50 per cent of the food collected for the target child was substituted or shared within the family, and of the energy ingested by the child, roughly 27 per cent could be accounted for by growth. According to Beaton (1983) the remaining 73 per cent may have gone into increased voluntary physical activity and possibly metabolic adaptation. Applying these estimates to the results in this study, an extra $200 \mathrm{kcal}$ per consumer unit might translate into $100 \mathrm{kcal}$ per child consumer per day if food were distributed equitably according to need - which is not at all certain). If 27 per cent of this would have gone into growth (i.e. $27 \mathrm{kcal}$ per day), it might have resulted in an extra weight increase over a period of 3-4 months of $3.4 \mathrm{~g}$ per day, or $100 \mathrm{~g}$ per month. For children, aged 310 years, the increase in maintenance requirements is much less $(22.5 \mathrm{kcal}$ instead of 61 $\mathrm{kcal} / \mathrm{kg} /$ day), so for them an extra $27 \mathrm{kcal} /$ day might theoretically result in body growth of $4.4 \mathrm{~g}$ per day or $135 \mathrm{~g}$ per month.

\section{Chapter 7}

45 Noticing that on many farms the areal used for food crop cultivation is relatively small it was recommended that food crop cultivation should be extended. This could also reduce the damage caused by wild animals and birds. Measures to stop further soil erosion are also important. The range of food crops should be stimulated; especially the cultivation of more drought-resistent crops such as cassava, sorghum, millet, simsim, groundnuts, soya beans, cowpeas, pigeon peas, yams, and arrow roots. Farmers might also be assisted at the time of planting, with rain forecasts through the media in the local languages. Irrigation possibilities are few because of the seasonal character of most rivers. Nevertheless, wherever possible, small-scale irrigation for, for instance, vegetable gardens should be encouraged. A positive side-effect of such measures could also be a less one-sided diet.

Productivity of food crop cultivation can be raised in several ways, such as more use of fertilizers and manure, better control of weeds, and the introduction of animal traction and 
other ways of mechanization. Extension services should be intensified and be directed to education and stimulation of such improvements. In general, higher farm productivity can only be realized through higher inputs; in other words, farmers need money to purchase these items and credit facilities should be provided with easy terms. Still, for many households such investments in food crop cultivation may not be economically viable. Potentially, cassava, could be of great importance, because it is already grown widely and used to be one of the main staples. It is possible that with rising maize prices as a result of changes in government policy, households may increase their cassava consumption although such an outcome is far from assured because food preferences are notoriously resistant to change.

Cash crop production is hampered by the same physical and cultivation constraints as food crop production, although it is clear that particularly in the wetter zones, potential for cash crops exists. In general, what has been said about measures to increase food crop production applies to cash crop production as well. But there is another problem: except for coconuts (copra), there is no assured market for cash crops in the two districts. Better marketing facilities for products such as cashewnuts and fruits should be explored, including the creation of agro-based industries in the areas.

Cattle-keeping should be encouraged for instance by extending the quite successful Dairy Development Project which focuses on zero and semi-zero grazing of dairy cows. A precondition, however, is that animal disease control must be intensified in order to reduce loss of animals. Farmers should receive better instruction on the care of their animals and be motivated to increase milk production. In order to increase the profitability for the farmers, the cultivation of fodder crops should be increased, for instance by integrating the project with agro-forestry and by creating nurseries for the fodder plants. Conservation of fodder crops should be stimulated, so that fodder can be used during the dry season. Moreover, the marketing of milk should be improved, for instance through decentralization of the marketing or through co-operative marketing groups of farmers. (The above is a summary of the recommendations in Foeken \& Hoorweg 1991) 
References 
ADAMS, A.M. (1994)

Seasonal variations in nutritional risk among children in Central Mali.

Ecology of Food and Nutrition, 33, 93-106.

AMREF (1982)

Report on the regional workshop on seasonal variations in the provisioning, nutrition and health of rural families, March 31-April 2. Nairobi: African Medical and Research Foundation.

ANDERSEN, K.B. (1977)

African traditional architecture: A study of the housing and settlement patterns of rural Kenya. Nairobi: Oxford University Press.

APELDOORN, G. J. van (1981)

Perspectives on drought and famine in Nigeria. London: George Allen \& Unwin.

BAHUCHET, S. (1988)

Food supply uncertainty among the Aka Pygmies (Lobaye, Central African Republic). In I. de Garine \& G.A. Harrison, eds., Coping with uncertainty in food supply, pp. 118-149. Oxford: Clarendon Press.

BAILEY, R.C. \& N.R. PEACOCK (1988)

Efe Pygmies of northeast Zairre: subsistence strategies in the Ituri forest. In I. de Garine \& G.A. Harrison, eds., Coping with uncertainty in food supply, pp. 88-117. Oxford: Clarendon Press.

BANTJE, H. \& R. NIEMEIJER (1984)

Rainfall and birthweight distribution in rural Tanzania.

Journal of Biosocial Science, 16, 375-384.

BARTMAN, C. (1984)

Livestock and small scale farmers: A description of the situation around Kilifi.

Wageningen: Agricultural University, Training Project in Pedology.

BAUMGARTNER, R.N., A.F. ROCHE \& J.H. HIMES (1986)

Incremental growth tables: supplementary to previously published charts.

American Journal of Clinical Nutrition, 43, 711-722.

BAYLISS-SMITH, T. (1981)

Seasonality and labour in the rural energy balance. In R. Chambers, R. Longhurst \& A. Pacey, eds., Seasonal dimensions to rural poverty, pp. 30-38. London: Frances Pinter.

BEATON, G.H. (1983)

Evaluation of nutrition interventions: Methodological considerations. American Journal of Clinical Nutrition, 35, 1280-1289.

BEATON, G.H. \& H. GHASSEMY (1983)

Supplementary feeding programs for young children in developing countries. American Journal of Clinical Nutrition, 35, 864-916.

BEINUM, G.G. van, T. KLIEST, W. van SCHIE \& M. SNIJDOODT (1985)

Rural housing conditions in Kwale District, Kenya. Nairobi / Utrecht: University of Nairobi, Housing Research and Development Unit / University of Utrecht, Department of Geography.

BERNUS, E. (1988)

Seasonality, climatic fluctuations, and food supplies (Sahelian nomadic pastoral societies). In I. de Garine \& G.A. Harrison, eds., Coping with uncertainty in food supply, pp. 318-336. Oxford: Clarendon Press.

BLANKHART, D.M. (1982)

Human nutrition. In L.C. Vogel, A.S. Muller, R.S. Odingo, Z. Onyango \& A. de Geus, eds., Health and disease in Kenya, pp. 409-427. Nairobi: Kenya Literature Bureau. 
BOERMA, J.T. \& F.J. BENNETT (i.p.)

Health at the Kenya Coast. In D. Foeken, J. Hoorweg \& R. Obudho, eds., Kenya Coast Handbook: Regional development in social perspective (in preparation).

BOXEM, H.W., T. de MEESTER \& E.M.A. SMALING, eds. (1987) Soils of the Kilifi area, Kenya. Wageningen: PUDOC.

BRADLEY, D. (1981)

Seasonal variables in infective disease: A summary. In R. Chambers, R. Longhurst \& A. Pacey, eds., Seasonal dimensions to rural poverty, pp. 127-131. London: Frances Pinter.

BRAUN, H.M.H. (1985)

Average monthly rainfall as a percentage of the annual rainfall in Kenya and Tanzania, with particular reference to the Kenyan Coast. Nairobi: Ministry of Agriculture, Kenya Soil Survey.

CAMPBELL, D.J. \& D.D. TRECHTER (1982)

Strategies for coping with food consumption shortage in the Mandera Mountain

Region of North Cameroon. Social Science \& Medicine, 16, 2117-2127.

CARLSEN, J. (1980)

Economic and social transformation in rural Kenya. Uppsala: Scandinavian Institute of African Studies, Centre for Development Research, Publication no. 4.

CBS (1970)

Kenya Population Census 1969, vol. 1. Nairobi: Ministry of Finance and Economic Planning, Central Bureau of Statistics.

CBS (1977)

The Rural Kenyan Nutrition Survey. Social Perspectives, vol. 4, no. 2.

(Nairobi: Central Bureau of Statistics).

CBS (1979a)

Report of the Child Nutrition Survey, 1978-1979.

Nairobi: Central Bureau of Statistics.

CBS (1979b)

Child nutrition in rural Kenya.

Nairobi: Central Bureau of Statistics.

CBS (1981a)

Kenya Population Census 1979, vol. 1.

Nairobi: Ministry of Planning and Development, Central Bureau of Statistics.

CBS (1981b)

The Integrated Rural Surveys, 1976-79; basic report.

Nairobi: Central Bureau of Statistics.

CBS (1983)

Third Rural Child Nutrition Survey 1982.

Nairobi: Ministry of Finance and Planning, Central Bureau of Statistics.

CBS (1988)

Economic Survey 1988.

Nairobi: Ministry of Planning and National Development, Central Bureau of Statistics.

CBS (1989)

Economic Survey 1989.

Nairobi: Ministry of Planning and National Development, Central Bureau of Statistics.

CBS (1990)

Statistical Abstract 1990.

Nairobi: Ministry of Planning and National Development, Central Bureau of Statistics. 
CBS (1991)

Fourth Rural Child Nutrition Survey, 1987.

Nairobi: Ministry of Planning and National Development, Central Bureau of Statistics.

CBS (1994)

Kenya Population Census, Volume I. Nairobi: Office of the Vice-President/Ministry of Planning and National Development, Central Bureau of Statistics.

CHAMBERS, R. (1981)

Introduction. In R. Chambers, R. Longhurst \& A. Pacey, eds., Seasonal dimensions to rural poverty, pp. 1-8. London: Frances Pinter.

CHAMBERS, R., R. LONGHURST, D. BRADLEY \& R. FEACHEM (1979)

Seasonal dimensions to rural poverty: analysis and practical implications.

Brighton: University of Sussex, Institute of Development Studies (Discussion Paper).

CHAMBERS, R., R. LONGHURST \& A. PACEY, eds. (1981)

Seasonal dimensions to rural poverty. London: Frances Pinter.

CIEKAWY, D. (1988)

Land tenure reform in Kenya's Southern Kilifi District, 1955-1987.

Journal of Eastern African Research \& Development, 18, 164-180.

CLEAVE, J.H. (1974)

African farmers: labor use in the development of smallholder agriculture.

New York/London: Praeger Publishers.

COOPER, F. (1981)

From slaves to squatters: Plantation labour and agriculture in Zanzibar and Coastal Kenya, 1890-1925. New Haven / Nairobi: Yale University Press / Kenya Literature Bureau.

COSTELLO, A.M.de LEON (1989)

Growth velocity and stunting in rural Nepal.

Archives of Disease in Childhood, 64, 1478-1482.

DIETZ, T. (1987)

Pastoralists in dire straits. Survival strategies and external interventions in a semi-arid region at the Kenya/Uganda border; Western Pokot, 1900-1986. Utrecht: KNAG, Netherlands Geographical Studies 49.

DIETZ, T. (1990)

Seasonality and the rhythm of external interference. In D. Foeken \& A. den Hartog, eds., Seasons, food supply and nutrition in Africa: contributions to a workshop held in Wageningen on December 14, 1988, pp. 89-110. Leiden: African Studies Centre, Research Report 43.

DYSON, T. \& N. CROOK (1981)

Causes of seasonal fluctuations in vital events. In R. Chambers, R. Longhurst \& A. Pacey, eds., Seasonal dimensions to rural poverty, pp. 135-141. London: Frances Pinter.

EERENBEEMT, M.L. van den (1985)

A demographic profile of the Fulani of Central Mali with special emphasis on infant and child mortality. In A.G. Hill, ed., Population, health and nutrition in the Sahel. Issues in the welfare of selected West African communities, pp. 79-103. London: Routledge \& Kegan Paul.

\section{ELLSWORTH, L. \& K. SHAPIRO (1989)}

Seasonality in Burkina Faso grain marketing: farmer strategies and government policy. In D.E. Sahn, ed., Seasonal variability in Third World agriculture: the consequences for food security, pp. 196-205. Baltimore: Johns Hopkins University Press. 
ENSMINGER, J. (1985)

The commercialization of pastoralists: effects of seasonality, age, gender, and wealth upon time allocation. Paper presented at the IFPRI workshop on Seasonal causes of household food insecurity; policy implications and research needs, Annapolis, Maryland.

FAO (1958)

Food and agricultural developments in Africa.

Rome: Food and Agriculture Organization.

FAO (1987)

Fifth World Food Survey.

Rome: Food and Agriculture Organization.

FAO (1992)

Body mass index: A measure of chronic energy deficiency in adults.

Rome: Food and Agriculture Organization. Food and Nutrition Paper no. 56.

FERRO-LUZZI, A., G. PASTORE \& S. SETTE (1987)

Seasonality in energy metabolism. In B. Schürch \& N.S. Scrimshaw, eds., Chronic energy deficiency: consequences and related issues, pp. 37-58. Lausanne: I/D/E/C/G.

FERRO-LUZZI, A. (1990)

Seasonal energy stress in marginally nourished rural women: interpretation and integrated conclusions of a multicentre study in three developing countries. European Journal of Clinical Nutrition, 44 (Suppl. 1), 41-46.

FLOOR, J. (1981)

Coconuts around Kaloleni, Kilifi District, Kenya.

Kilifi: Training Project in Pedology (TPIP), Preliminary Report no. 2.

FOEKEN, D. (1994)

Climatic seasonality in Kenya with special reference to Coast Province.

Eastern and Southern Africa Geographical Journal, 5, 28-43.

FOEKEN, D. \& A. den HARTOG, eds. (1990)

Seasons, food supply and nutrition in Africa: contributions to a workshop held in Wageningen on December 14, 1988. Leiden: African Studies Centre, Research Report 43.

FOEKEN, D. \& J. HOORWEG (1988)

Seasonality in the Coastal Lowlands of Kenya. Part 2: Introduction to seasonality. Nairobi / Leiden: Ministry of Planning \& National Development / African Studies Centre, Food and Nutrition Studies Programme, Report no. 28.

FOEKEN, D. \& J. HOORWEG, eds. (1991)

Socio-economic and nutritional studies in Coast Province: summaries and recommendations. Proceedings of a seminar at Diani, 28-30th November 1990.

Nairobi / Leiden: Ministry of Planning \& National Development / African Studies Centre, Food and Nutrition Studies Programme, Report no. 40.

FOEKEN, D., P. LEEGWATER, R. NIEMEIER, W. VEERMAN \& J. HOORWEG (1989) Seasonality in the Coastal Lowlands of Kenya. Part 3: Socio-economic profile. Nairobi / Leiden: Ministry of Planning \& National Development / African Studies Centre, Food and Nutrition Studies Programme, Report no. 32.

FOEKEN, D. \& N. TELLEGEN (1994)

Tied to the land: Living conditions of labourers on large farms in Trans Nzoia District, Kenya. Oxford / Leiden: Avebury / African Studies Centre. ASC Research Series no. 1

FORTES, M. \& S.L. FORTES (1936)

Food in the domestic economy of the Tallensi. Africa, 9, 2, 237-276. 
FORTMANN, L. (1985)

Seasonal dimensions of rural social organisations.

Journal of Development Studies, 21, 377-389.

FOWLER, A.F. (1982)

Seasonal aspects of education in Eastern Africa. In AMREF, Report on the regional workshop on seasonal variations in the provisioning, nutrition and health of rural families, March 31-April 2, pp. 58-73. Nairobi: African Medical and Research Foundation.

GARINE, I. de \& G.A. HARRISON, eds. (1988a)

Coping with uncertainty in food supply.

Oxford: Clarendon Press.

GARINE, I. de \& G.A. HARRISON (1988b)

Discussion and conclusions. In I. de Garine \& G.A. Harrison, eds., Coping with uncertainty in food supply, pp. 469-475. Oxford: Clarendon Press.

GARINE, I. de \& G. KOPPERT (1988)

Coping with seasonal fluctuations in food supply among savanna populations: the Massa and Mussey of Chad and Cameroon. In I. de Garine \& G.A. Harrison, eds., Coping with uncertainty in food supply, pp. 210-259. Oxford: Clarendon Press.

GEIST, J.K. (1981)

Coastal agrarian underdevelopment and regional imbalance in Kenya.

Berkeley: University of California, Ph.D. thesis.

GEUNS, M., R. NIEMEIJER \& J. HOORWEG (1991)

Child nutrition in the pre-harvest season in Kenya.

East African Medical Journal, 68, 93-105.

GILL, G.J. (1991)

Seasonality and the developing world: a problem of the poor and the powerless.

Cambridge: Cambridge University Press.

GOETZ, J.P. (1981)

A study of childhood disease in Tanzania. In R. Chambers, R. Longhurst \& A. Pacey, eds., Seasonal dimensions to rural poverty, pp. 182-186. London: Frances Pinter.

GOK (1986)

Sessional Paper No.1 of 1986 on economic management of renewed growth.

Nairobi: Government of Kenya.

GOK (1993)

Economic Survey 1993.

Nairobi: Government of Kenya.

GOK (1994a)

Sessional Paper No.1 of 1994 on recovery and sustainable development to the year

2010. Nairobi: Government of Kenya.

GOK (1994b)

Sessional Paper No 2 of 1994 on national food policy.

Nairobi: Government of Kenya.

GOK/UNICEF (1992)

Children and women in Kenya: A situation analysis 1992.

Nairobi: UNICEF.

GORDON, H. \& N. SPOONER (1992)

Grain marketing in Kenya: Principle and practice. In W. Nguyo, ed., Proceedings of the conference on maize supply and marketing under market liberalization.

Njoro: Egerton University. 
GREER, J. \& E. THORBECKE (1986)

Food poverty and consumption patterns in Kenya.

Geneva: International Labour Office.

GUYER, J. (1989)

From seasonal income to daily diet in a partially commercialized rural economy (Southern Cameroon). In D.E. Sahn, ed., Seasonal variability in Third World agriculture: the consequences for food security, pp. 137-150. Baltimore: Johns Hopkins University Press.

HAAGA, J.G. (n.d.)

Negative bias in estimates of the correlation between children's weight-for-height and height-for-age. Ithaca, Cornell University, Cornell Nutrition Surveillance Programme, mimeo (about 1983).

HAAGA, J., J. MASON, F.Z. OMORO, V. QUINN, A. RAFFERTY, K. TEST \& L.WASONGA (1986) Child malnutrition in rural Kenya: Geographic and agricultural classification. Ecology of Food and Nutrition, 18, 297-307.

HAAGA, J.G., \& J.B. MASON (1987)

Food distribution within the family. Evidence and implications for research and programmes. Food Policy, 12, 2, 146-160.

HARTOG, A.P. den \& I.D. BROUWER (1990)

Adjustment of food habits in situations of seasonality. In D. Foeken \& A. den Hartog, eds., Seasons, food supply and nutrition in Africa: contributions to a workshop held in Wageningen on December 14, 1988, pp. 76-88. Leiden: African Studies Centre, Research Report no. 43.

HERLEHY, TH. J. (1983)

An historical dimension of the food crisis in Africa: surveying famines along the Kenyan coast, ca. 1880-1980. Paper presented at the 26th Annual Meeting of the African Studies Association, Boston, Mass., Dec. 7-10.

HOORWEG, J. (1993)

FNSP studies, 1985-1992: Results \& Recommendations.

Nairobi / Leiden: Ministry of Planning \& National Development / African Studies Centre, Food and Nutrition Studies Programme, Report no. 50.

HOORWEG, J., T. KLIEST \& R. NIEMEIJER (1988) Seasonality in the Coastal Lowlands of Kenya. Part 1: Research objectives and study design. Nairobi / Leiden: Ministry of Planning \& National Development / African Studies Centre, Food and Nutrition Studies Programme, Report no. 27.

HOORWEG, J. \& R. NIEMEIJER (1989)

Intervention in child nutrition: Evaluation studies in Kenya. London: Kegan Paul.

HOORWEG, J. \& P. LEEGWATER (i.p.)

Nutrition in agricultural development: Dairy farming in Kilifi District, Kenya (in preparation).

JAETZOLD, R. \& H. SCHMIDT (1983)

Farm Management Handbook of Kenya, Vol. II: Natural conditions and farm management information; Part C: East Kenya. Nairobi: Ministry of Agriculture.

JIGGINS, J. (1986)

Women and seasonality: coping with crisis and calamity. IDS Bulletin, 17, 3, 9-18.

KENNEDY, E. (1994)

Effects of sugarcane production in Southwestern Kenya on income and nutrition. In J. von Braun \& E. Kennedy, eds., Agricultural commercialization, economic 
development and nutrition. pp. 252-263. Baltimore: Johns Hopkins University Press.

KIGUTHA, H. (1994)

Household food security and nutritional status of vulnerable groups in Kenya: A seasonal study among low income smallholder rural households. Wageningen: Agricultural University, Ph.D. thesis.

KLIEST, T. (1985)

Regional and seasonal food problems in Kenya.

Nairobi / Leiden: Ministry of Planning \& National Development / African Studies Centre, Food and Nutrition Studies Programme, Report no. 10.

KUMAR, S.K. (1985)

Household production and consumption strategies for meeting seasonal labour needs. Paper presented at the IFPRI workshop on Seasonal causes of household food insecurity; policy implications and research needs, Annapolis, Maryland.

LATHAM, M.C. (1993)

The relationship of nutrition to productivity and well-being of workers.

In P. Pinstrup-Andersen, ed., The political economy of food and nutrition policies, pp. 133-148. Baltimore: Johns Hopkins University Press.

LAWRENCE, M., F. LAWRENCE, T.J. COLE, W.A. COWARD, J. SINGH \& R.G. WHITEHEAD (1989), Seasonal pattern of activity and its nutritional consequence in Gambia. In D.E. Sahn, ed., Seasonal variability in Third World agriculture: the consequences for food security, pp. 47-56. Baltimore: Johns Hopkins University Press.

LEEGWATER, P., J. NGOLO \& J. HOORWEG (1991)

Nutrition and dairy development in Kilifi District.

Nairobi / Leiden: Ministry of Planning \& National Development / African Studies Centre, Food and Nutrition Studies Programme, Report no. 35.

LIERE, M. van, E.D. ATEGBO, J. HOORWEG, A.P. den HARTOG \& J.G.A.J. HAUTVAST (1994) The significance of socio-economic characteristics for adult seasonal body-weight fluctuations: A study in north-western Benin. British Journal of Nutrition, 72, 479488.

LONGHURST, R., ed. (1986a)

Seasonality and poverty. Special issue of IDS Bulletin (vol. 17, no. 3).

LONGHURST, R. (1986b)

Household food strategies in response to seasonality and famine.

IDS Bulletin, 17, 3, 27-35.

LONGHURST, R. \& P. PAYNE (1981)

Seasonal aspects of nutrition. In R. Chambers, R. Longhurst \& A. Pacey, eds., Seasonal dimensions to rural poverty, pp. 45-52. London: Frances Pinter.

LOUTAN, L. (1985)

Nutrition amongst a group of WoDaaBe (Bororo) pastoralists in Niger.

In A.G. Hill, ed., Population, health and nutrition in the Sahel. Issues in the welfare of selected West African communities, pp. 208-224. London: Routledge \& Kegan Paul.

LYNN, C.W. (1937)

Agriculture in North Mamprusi.

Gold Coast Department of Agriculture Bulletin, no. 34 (Accra).

MARITIM, H.K. (1982)

Maize marketing in Kenya: An assessment of interregional commodity flow patterns. Berlin: Technische Universität, Institut fur Sozialökonomie der Agrarentwicklung. $\mathrm{Ph} . \mathrm{D}$. thesis.

MASAI, W. (1983)

The nutritional status of Kenyans and major factors influencing it. 
In L.M. Wasonga \& J.O. Otieno, eds., Proceedings of a workshop on nutrition in agricultural development projects, pp. 3-59. Nairobi: Ministry of Economic Planning \& Development.

MATLON, P.J. \& P.M. KRISTJANSON (n.d.)

Farmer risk management in the West-African semi-arid tropics.

Unpublished paper.

MBITHI, P.M. \& B. WISNER (1973)

Drought and famine in Kenya. Magnitude and attempted solutions.

Journal of Eastern African Research \& Development, 3, 2, 113-143.

MCGREGOR, I.A., A.K. RAHMAN, B. THOMPSON, W.Z. BILLEWICZ \& A.M. THOMSON (1968) The growth of young children in a West African (Gambian) village.

Transactions of the Royal Society of Tropical Medicine and Hygiene, 62, 341-352.

MEILINK, H. (1985)

Agricultural pricing policy in Kenya: scope and impact.

Nairobi / Leiden: Ministry of Planning \& National Development / African Studies

Centre, Food and Nutrition Studies Programme, Report no. 11.

MEILINK, H. (1987)

Food consumption and food prices in Kenya: a review.

Nairobi / Leiden: Ministry of Planning \& National Development / African Studies

Centre, Food and Nutrition Studies Programme, Report no. 21.

MEILINK, H. (i.p)

Regional differentiation in Kenya: The Coast Province position. In D. Foeken, J. Hoorweg \& R. Obudho , eds., Kenya Coast Handbook: Regional development in social perspective (in preparation).

MENR (1984a)

Kilifi District environmental assessment report. Nairobi: Ministry of Environment and National Resources, National Environment and Human Settlements Secretariat.

MENR (1984b)

Kwale District environmental assessment report. Nairobi: Ministry of Environment and National Resources, National Environment and Human Settlements Secretariat.

MESSER, E. (1989)

Seasonality in food systems: an anthropological perspective on household food security. In D.E. Sahn, ed., Seasonal variability in Third World agriculture: the consequences for food security, pp. 151-175. Baltimore: Johns Hopkins University Press.

MFP (1984a)

Kilifi District Development Plan 1984/1988.

Nairobi: Ministry of Finance and Planning.

MFP (1984b)

Kwale District Development Plan 1984/1988.

Nairobi: Ministry of Finance and Planning.

MOA (1985)

Kilifi District Annual Report, 1984.

Nairobi: Ministry of Agriculture.

MOA (1986)

Kilifi District Annual Report, 1985.

Nairobi: Ministry of Agriculture.

MORIS, J.R. (1989)

Indigenous versus introduced solutions to food stress in Africa.

In D.E. Sahn, ed., Seasonal variability in Third World agriculture: the consequences 
for food security, pp. 209-234. Baltimore: Johns Hopkins University Press.

NDAGALA, D.K. (1981)

Pastoralists and cultivators in Bagamoyo District. In R. Chambers, R. Longhurst \& A. Pacey, eds., Seasonal dimensions to rural poverty, pp. 186-191. London: Frances Pinter.

NIEMEIJER, R., D. FOEKEN \& W. KLAVER (1991)

Seasonality in the Coastal Lowlands of Kenya, Part 4/5: Food consumption and anthropometry. Nairobi / Leiden: Ministry of Planning \& National Development / African Studies Centre, Food and Nutrition Studies Programme, Report no. 38.

NIEMEIJER, R. \& J. HOORWEG (1994)

Commercialization of rice and nutrition: A case from West Kenya.

In J. von Braun \& E. Kennedy, eds., Agricultural commercialization, economic development and nutrition. pp. 264-275. Baltimore: Johns Hopkins University Press.

NIEMEIJER, R. \& W. KLAVER (1990)

Climatic seasonality and growth; longitudinal research in Coast Province, Kenya.

In D. Foeken \& A. den Hartog, eds., Seasons, food supply and nutrition in Africa:

contributions to a workshop held in Wageningen on December 14, 1988, pp. 30-65.

Leiden: African Studies Centre, Research Report no. 43.

OGBU, J.M. (1973)

Seasonal hunger in tropical Africa as a cultural phenomenon.

Africa, 43, 317-332.

ONCHERE, S.R. \& R. SLOOFF (1981)

Nutrition and disease in Machakos District, Kenya. In R. Chambers, R. Longhurst \& A. Pacey, eds., Seasonal dimensions to rural poverty, pp. 41-45. London: Frances Pinter.

OOSTEN, C. van (1989)

Farming systems and food security in Kwale District, Kenya. Nairobi / Leiden:

Ministry of Planning \& National Development / African Studies Centre, Food and

Nutrition Studies Programme, Report no. 30.

PAGEZY, H. (1988)

Coping with uncertainty in food supply among the Oto and the Twa living in the equatorial flooded forest near Lake Tumba, Zaïre. In I. de Garine \& G.A. Harrison, eds., Coping with uncertainty in food supply, pp. 175-209. Oxford: Clarendon Press.

PALMER, I. (1981)

Seasonal dimensions of women's roles. In R. Chambers, R. Longhurst \& A. Pacey, eds., Seasonal dimensions to rural poverty, pp. 195-201. London: Frances Pinter.

PAOLISSO, M., M. BAKSH \& J.C. THOMAS (1990)

Women's agricultural work, child care, and infant diarrhea in rural Kenya.

In J. Leslie \& M. Paolisso, eds., Women, work, and child welfare in the Third World, pp. 217-236. Boulder: Westview Press, AAAS Selected Symposia Series 110.

PARISIER, E.R. (1982)

Post-harvest food losses in developing countries: A survey.

In N.S. Scrimshaw \& M.B. Wallerstein, eds., Nutrition policy implementation: Issues and experience, pp. 337-372. New York: Plenum Press.

PAYNE, P. (1989)

Public health and functional consequences of seasonal hunger and malnutrition.

In D.E. Sahn, ed., Seasonal variability in Third World agriculture, pp. 19-46.

Baltimore, Md: Johns Hopkins University Press.

PETERS, C. \& R. NIEMEIJER (1987)

Protein-energy malnutrition and the home environment: a study among children in 
Coast Province, Kenya. Nairobi / Leiden: Ministry of Planning and National Development / African Studies Centre, Food \& Nutrition Studies Programme, Report no. 22.

RAIKES, P. (1981)

Seasonality in the rural economy (of tropical Africa). In R. Chambers, R. Longhurst \& A. Pacey, eds., Seasonal dimensions to rural poverty, pp. 67-73. London: Frances Pinter.

REARDON, T., P. MATLON \& C.L. DELGADO (1988)

Coping with household-level food insecurity in drought-affected areas of Burkina Faso. World Development, 16, 9, 1065-1074.

REARDON, T. \& P. MATLON (1989)

Seasonal food insecurity and vulnerability in drought-affected regions of Burkina

Faso. In D.E. Sahn, ed., Seasonal variability in Third World agriculture: the consequences for food security, pp. 118-136. Baltimore: Johns Hopkins University Press.

REMPEL, H. (1981)

Seasonal out-migration and rural poverty. In R. Chambers, R. Longhurst \& A. Pacey, eds., Seasonal dimensions to rural poverty, pp. 210-214. London: Frances Pinter.

RICHARDS, A.I. (1939)

Land, labour and diet in Northern Rhodesia.

London: Oxford University Press.

ROWLAND, M.G.M., A. PAUL, A.M. PRENTICE, E. MÜLLER, M. HUTTON, R.A.E. BARRELL \& R.G. WHITEHEAD (1981), Seasonality and the growth of infants in a Gambian village. In R. Chambers, R. Longhurst \& A. Pacey, eds., Seasonal dimensions to rural poverty, pp. 164-175. London: Frances Pinter.

SAHN, D.E., ed. (1989)

Seasonal variability in Third World agriculture: the consequences for food security. Baltimore: Johns Hopkins University Press.

SAHN, D.E. \& C. DELGADO (1989)

The nature and implications for market interventions of seasonal food price variability. In D.E. Sahn, ed., Seasonal variability in Third World agriculture: the consequences for food security, pp. 179-195. Baltimore: Johns Hopkins University Press.

SCHOFIELD, S. (1974)

Seasonal factors affecting nutrition in different age groups and especially pre-school children. Journal of Development Studies, 11, 1, 22-40.

SCHREURS, W. (1982)

Farming systems in the Bamba-Ganze area, Kilifi District, Kenya.

Kilifi: Training Project in Pedology (TPIP).

SCHULTINK, J.W. (1991)

Seasonal changes in energy balance of rural Beninese women.

Wageningen: Agricultural University, Department of Human Nutrition.

SIMMONS, E.B. (1981)

A case-study in food production, sale and distribution. In R. Chambers, R. Longhurst \& A. Pacey, eds., Seasonal dimensions to rural poverty, pp. 73-80. London: Frances Pinter.

SMALING, E.M.A. \& H.W. BOXEM (1987)

Climate and agro-climatic zonation. In H.W. Boxem, T. de Meester \& E.M.A. Smaling, eds., Soils of the Kilifi area, Kenya, pp. 9-20. Wageningen: PUDOC.

SOME, D.K., H.K. MARITIM \& F.J. FARAJ (1993)

Food inventories at the farm level. In P. Berck \& D. Bigman, eds., Food security and food inventories in developing countries, pp. 329-337. Washington: CAB Inter- 
national.

SPEAR, T. T. (1978)

The Kaya complex: a history of the Mijikenda peoples of the Kenya coast to 1900. Nairobi: Kenya Literature Bureau.

SWIFT, J. (1981)

Labour and subsistence in a pastoral economy. In R. Chambers, R. Longhurst \& A. Pacey, eds., Seasonal dimensions to rural poverty, pp. 80-87. London: Frances Pinter.

SWINDELL, K. (1984)

Farmers, traders, and labourers: Dry season migration from north-west Nigeria, 190033. Africa, 54, 1, 3-19.

TELLEGEN, N. (1993)

Rural employment in Sub-Saharan Africa: a bibliography.

Leiden: African Studies Centre, Working Paper no. 18.

TOMKINS, A. (1981)

Seasonal health problems in the Zaria region. In R. Chambers, R. Longhurst \& A. Pacey, eds., Seasonal dimensions to rural poverty, pp. 177-181. London: Frances Pinter.

TOULMIN, C. (1986)

Access to food, dry season strategies and household size amongst the Bambara of Central Mali. IDS Bulletin, 17, 3, 58-66.

VELDHUIS, M. (1981)

Gevolgen van arbeidsmigratie voor het herkomstgebied. Een analyse van de effekten op de agrarische produktie, het inkomen en de positie van de vrouw in de migranten huishoudens in Matheini, Machakos District, Kenya. ("The impact of labour migration on the area of origin. An analysis of the effects on agricultural production, income and position of women in the migrant's households in Matheini, Machakos District, Kenya"). Amsterdam: University of Amsterdam, M.A. thesis.

VERVOORN, M. \& H. WAAIJENBERG (1986)

Een boerenbedrijf in Kaloleni, Kenia ("A farm in Kaloleni, Kenya").

Wageningen: Agricultural University, unpublished thesis.

WAAIJENBERG, H. (1987)

Agriculture in the Kilifi Area (Mapsheet 198), Kenya. In H.W. Boxem, T. de Meester \& E.M.A. Smaling, eds., Soils of the Kilifi area, Kenya, pp. 195-247. Wageningen: PUDOC.

WAAIJENBERG, H. (1993)

Land and labour in Mijikenda agriculture: Kenya, 1850-1985.

Leiden: African Studies Centre. Research Report no. 53.

WAAIJENBERG, H. (1994)

Mijikenda agriculture in Coast Province of Kenya: peasants in between tradition, ecology and policy. Amsterdam: KIT Press.

WAAIJENBERG, H. \& M. SALIM (1983)

Land and farming systems in Kilifi District, Kenya. Paper presented at a farming systems workshop, Magarini Settlement Scheme, December 7-9, Malindi.

WADDY, B.B. (1981)

Poverty, housing and disease. In R. Chambers, R. Longhurst \& A. Pacey, eds., Seasonal dimensions to rural poverty, pp. 175-177. London: Frances Pinter.

WALKER, S.P. \& M.H.N. GOLDEN (1988)

Growth in length of children recovering from severe malnutrition.

European Journal of Clinical Nutrition, 42, 395-404. 
WALSH, R.P.D. (1981)

The nature of climatic seasonality. In R. Chambers, R. Longhurst \& A. Pacey, eds., Seasonal dimensions to rural poverty, pp. 11-21. London: Frances Pinter.

WATERLOW, J.C. (1994)

Relationship of gain in height to gain in weight.

European Journal of Clinical Nutrition, 48 (Supplement on causes and mechanism of linear growth retardation), S72-S74.

WATTS, M. (1981)

The sociology of seasonal food shortage in Hausaland. In R. Chambers, R. Longhurst \& A. Pacey, eds., Seasonal dimensions to rural poverty, pp. 201-206. London: Frances Pinter.

WATTS, M. (1988)

Coping with the market: uncertainty and food security among Hausa peasants.

In I. de Garine \& G.A. Harrison, eds., Coping with uncertainty in food supply, pp. 260-289. Oxford: Clarendon Press.

WERE, G.S., D. NYAMWAYA \& H. IPU, eds. (1986)

Kenya socio-cultural profiles: Kwale District.

Nairobi: Ministry of Planning and National Development/University of Nairobi, Institute of African Studies (draft report).

WHEELER, E.F. \& M. ABDULLAH (1988)

Food allocation within the family: response to fluctuating food supply and food needs. In I. de Garine \& G.A. Harrison, eds., Coping with uncertainty in food supply, pp. 437-451. Oxford: Clarendon Press.

WHITE, C. (1986)

Food shortages and seasonality in WoDaaBe communities in Niger.

IDS Bulletin, 17, 3, 19-26.

WHO (1983)

Measuring change in nutritional status: Guidelines for assessing the nutritional impact of supplementary feeding programmes for vulnerable groups.

Geneva: World Health Organisation.

WHO/FAO (1985)

Energy and protein requirements.

Geneva: World Health Organization. Technical Report 724. 
. 


\section{Index}


absolute seasonality 7,33

agrarian cycle 6,34

agricultural calendar 35, 44

Agricultural Production Survey of 1986/87 121

agricultural productivity 60

agro-ecological zones $27,35-38,42$, $43,48,53,54,55,60,65,67,77-$ $78,80,84,90,91,93,97,105$

Aka 20

beans $40,44,58,71$

Benin 13, 103

birth weight 13

body mass index (BMI) $82,83,84,85$, $91,100,103$

body weight $7,8,13,14,82,89,92$, 100,124

Bongwe 120

Burkina Faso 12, 24, 25

Burma 100

Bushmen 22

caloric intake see energy intake

Cameroon 8, 19, 20, 24

cash crops $10,40,58,59,60,66,96$, $97,99,104,122,123,126$

cashewnuts $40,42,44,58,97,126$

cassava $17,21,40,42,43,44,56,58$, $69,73,74,77,79,96,97,104$, $120,124,125,126$

Central Africa 20, 21

cereals $40,56,58,72,73,74,124$

Chonyi 28, 51

climates

bimodal $7,11,13,33$

unimodal $7,11,12,13,33$

Coast Province 27, 28, 31, 33, 39, 40 , $41,45,46,48,79,85,87,96,97$, $98,100,101,119,122$

Coastal Lowlands 35

Coastal Plain 29, 31, 98

Coastal Range $31,33,39$

coconuts $40,42,44,58,73,96,97$, 126

consumer units 119

coping mechanisms $16,21,22,23,24$

curative 21-22, 95

food production 16-18

food purchases $18-19,80,91$

preventive $16-20,55,74,95,96-99$

redistribution of resources 20,21

crop cultivation $10,40,54,66,78$, $83,99,125$

Dairy Development Project 126

Diani Beach 62

Digo 28, 29, 56, 62, 69, 95, 97

Duruma 28, 29, 41, 95
East Africa 7, 9, 95

education $52,63,98,126$

employment $18,45,61-64,65,66$,

$96,98,99,100,101,102,104,120$

energy deficiency 82

energy expenditure $10,12,44,78,100$

energy intake $10,12,13,14,70-80$,

$84,85,89,90,91,94,100,101$,

$102,104,124,125$

origin of $73,75,76,77,78$

energy requirements $13,14,57,65$,

$70,71,100,119,120$

energy trap 105

famine foods 21

Fifth World Food Survey 122

food consumption $21,76,78,79,84$ $85,87,91,96,100,101,102,103$, 123

food groups 73, 74, 75, 124

Food Poverty Line $65,67,122$

food production $55-57,58,83,85,87$, 96, 97, 105

food purchases $73,74,76,78,79,80$, $96,104,124$

food security $48,57,104$

food self-sufficiency $46,57,75,77$, $79,103,104,120,122,124$

Foot Plateau 29, 31

Fulani 15

Gambia 10, 12, 13

gender $10,19,24,45,52,62,103$

Ghana 13, 118

Giriama 28, 29, 41, 51, 95, 98

group ranches 42

growing period $6,8,38,39,43,56$

Hausa 19

health 47

height growth $82,88,89,90,91,92$, $93,101,102,103$

height-for-age $82,85,87,88,92,125$

'hungry season' 5, 6, 97

Ibo 16

Integrated Rural Survey of $1974 / 75$ 122

Jibana 28

Kamba 95

Kambe 28

Kauma 28, 51

kaya 28

Kenya $10,11,12,15,17,19,22,27$, $28,45,52,69,70,71,87,91,93$, $100,105,118,121$

Kenya Government 104

Kenya Top Bar Hives 41 
Kibandaongo 120

livestock $9,10,40,41,59,60,66$, $96,98,102,122,123$

\section{macro-nutrients 71}

Madagascar 7

maize $40,42,43,44,46,54,56,61$, $71,74,79,80,95,96,97,104$, 124,126

Malawi 12

Mali 8, 15, 18, 20, 91

malnutrition $14,15,47,87,91,92$, 100

Massa 8, 19, 20

Mijikenda 28, 29, 95, 96, 97, 118, 124

Mikamini 51, 120

minimum existence level 66

Mombasa 28, 29, 41, 45, 51, 62, 99

Mussey 8, 19, 20

Myanmar 100

National Cereals and Produce Board 104

Niger 13, 24

Nigeria 14, 16, 19, 21, 22

Nyika Plateau 31, 33

off-farm employment see employment

Oto 17,20

pastoralists $9,10,11,13,15,18,22$, 24,118

Pokot 17, 22, 118

protein intake $72,102,123$

origin of 73

Pygmies 20, 22

Rabai 28, 29, 95

rain-fed agriculture $1,2,8,9,101$

relative seasonality 7,33

Ribe 28

Rural Household Budget Survey of 1981-82 64, 121

seasonal stress 7, 16, 21, 25, 101 seasonality

and food consumption 11, 73-79

and food prices 11, 104

and growth of children $89,90,91$, 93

and health 14-15, 47

and labour 9-11, 44

and nutrition $12-13,82-85,88$

and social activities 15-16

'classical scenario' $5,14,71,77$, $80,89,99$

climatic 6-9, 23, 33-35, 101

seasonality index 8, 33, 101
Shimba Hills 31

socio-economic differentiation 12,24 , $48,66,67,78,79,80,84-85,90$ $91,93,102,105$

Somali 118

Southem Africa 9

stunted children 47, 85, 87, 91

Swahili 28, 69, 95

Tanzania $10,13,14$

Twa 17,20

Twareg 18, 20

upper arm circumference 47

wage employment see employment wasted children $47,85,87$

weight growth $82,88,89,90,91,92$, 93, 101, 102, 103

weight-for-age 82,87

weight-for-height $13,47,82,85,87$,

$88,92,93,100,101,125$

WoDaaBe 13,24

Zaïre 17,20

Zambia 9, 11, 13 
Many African Societies traditionally have to cope with seasonal food shortages. It has been suggested that the effects of this kind of seasonality have worsened with increasing population pressure and with the introduction of commercial cropping and that small farmers particularly are vulnerable to the vagaries of the seasons.

This monograph examines the seasonal variations in food consumption and nutrition that occur in Kenya's Coast Province. This part of the country is relatively dry, has a largely unimodal climate and a low degree of food self-sufficiency. Household energy intake is the same as that of peasant smallholders elsewhere in Kenya. The nutritional status of children is below that in other parts of the country. Nevertheless the seasonal fluctuations in energy intake and nutritional status are small. The study population has developed successful strategies to cope with diminishing food stocks at the end of the agricultural year. Despite the fact that household incomes are generally low, households manage to increase their food purchases with income from off-farm employment. The respective influences of climate, productive organization and household income are analysed.

The findings are reviewed in relation to the changes in livelihood that have occurred in rural Africa; in respect of resource management and diversification strategies; and in relation to existing theories of child growth. Implications for development and policy are discussed.

Dick Foeken is head of the Department of Social and Economic Studies of the African Studies Centre. For the last ten years he has been involved in research projects in different parts of Kenya.

Jan Hoorweg is senior researcher at the African Studies Centre and Professor of Food Security and Nutrition Intervention at the Agricultural University, Wageningen.

Wijnand Klaver is staff member of the Sector Nutrition and Food Technology of the International Agricultural Centre, Wageningen and research fellow at the African Studies Centre.

\section{African Studies Centre Leiden}

